\title{
Review of Powder Bed Fusion Additive Manufacturing for Metals
}

\author{
Leila Ladani and Maryam Sadeghilaridjani *
}

Citation: Ladani, L.;

Sadeghilaridjani, M. Review of Powder Bed Fusion Additive

Manufacturing for Metals. Metals

2021, 11, 1391. https://doi.org/

$10.3390 /$ met11091391

Academic Editor: Aleksander Lisiecki

Received: 22 July 2021

Accepted: 26 August 2021

Published: 1 September 2021

Publisher's Note: MDPI stays neutral with regard to jurisdictional claims in published maps and institutional affiliations.

Copyright: (c) 2021 by the authors. Licensee MDPI, Basel, Switzerland. This article is an open access article distributed under the terms and conditions of the Creative Commons Attribution (CC BY) license (https:/ / creativecommons.org/licenses/by/ $4.0 /)$.
School for Engineering of Matter, Transport and Energy, Arizona State University, Tempe, AZ 85287, USA; ljannesa@asu.edu

* Correspondence: maryam.sadeghilaridjani@asu.edu

\begin{abstract}
Additive manufacturing (AM) as a disruptive technology has received much attention in recent years. In practice, however, much effort is focused on the AM of polymers. It is comparatively more expensive and more challenging to additively manufacture metallic parts due to their high temperature, the cost of producing powders, and capital outlays for metal additive manufacturing equipment. The main technology currently used by numerous companies in the aerospace and biomedical sectors to fabricate metallic parts is powder bed technology, in which either electron or laser beams are used to melt and fuse the powder particles line by line to make a three-dimensional part. Since this technology is new and also sought by manufacturers, many scientific questions have arisen that need to be answered. This manuscript gives an introduction to the technology and common materials and applications. Furthermore, the microstructure and quality of parts made using powder bed technology for several materials that are commonly fabricated using this technology are reviewed and the effects of several process parameters investigated in the literature are examined. New advances in fabricating highly conductive metals such as copper and aluminum are discussed and potential for future improvements is explored.
\end{abstract}

Keywords: powder bed fusion additive manufacturing; laser melting; electron beam melting; nickel alloys; titanium alloys; bulk metallic glasses; high entropy alloys; copper alloys; aluminum alloys; steel

\section{Introduction}

Additive manufacturing (AM) is a manufacturing technique for fabricating three dimensional (3D) products, and it has some exceptional attributes. It allows the production of unique and complex custom-made parts, which is unachievable by other manufacturing techniques. AM also has the potential to improve materials' efficiency, produce faster and more cost-effective products, save energy and emissions, and reduce intensive resource use [1]. Powder bed fusion (PBF) technology is a group of additive manufacturing (AM) technologies where an energy source is used to selectively bind or melt powder particles to build parts layer by layer to the desired geometry [2,3]. It is the most common type of technology for additive manufacturing of metallic parts for aerospace and biomedical applications [4]. The heat source can vary from pulsed laser to electron beam or even ultraviolet light. Since metals have very high melting temperatures, they require high energy density to consolidate the particles. Therefore, laser and electron beams are the most common types of heat source used with metal AM.

The outcome of both processes depends largely on the process parameters and interplay of physical phenomena that occur as shown in Figure 1. Several heat transfer mechanisms are active at a macro- and micro-scale. Micro-scale heat transfer occurs in between powder particles. Naturally, heat transfer is faster within the solid region than in the powder. The air gaps between the particles work as insulators that slow down the heat transfer. Conduction in powder is less efficient than in a continuous solid part since conductive transfer can only take place where particles are in physical contact with 
one another. In other words, the powder's effective thermal conductivity is lower compared to its solid material counterpart. The build plate is typically constructed of a highly thermally conductive material, and is adequately large, to act as a heat sink, facilitating the quick solidification of molten powder. Due to the complexity of thermal transport within the powder bed, an effective thermal conductivity is typically introduced. The effective conductivity is a metric to model conduction, convection, and radiation between particles in the powder bed as outlined in Figure 1. Radiation and convection, depending on the process used, are also modes of heat transfer at the macro-scale within the build chamber. Laser melting and laser sintering processes operate under inert atmospheres and allow convective cooling of the build surface [5]. EBM operates under a high vacuum and therefore cannot sustain convection within the build chamber [6]. Both processes contain radiation between individual particles in the powder bed as well as from the build surface to the inner surfaces of the build chamber. Previous modeling studies [7-9], however, suggest that radiative and convective cooling of the powder bed are insignificant compared to conduction. Radiation within the powder bed is typically included in effective thermal conductivity, as has been carried out in previous studies [7-10]. Other physical mechanisms that are active are melting and solidification, grain growth, fluid dynamic within the melt pool due to the Marangoni effect, powder wetting and shrinkage due to solidification, etc.

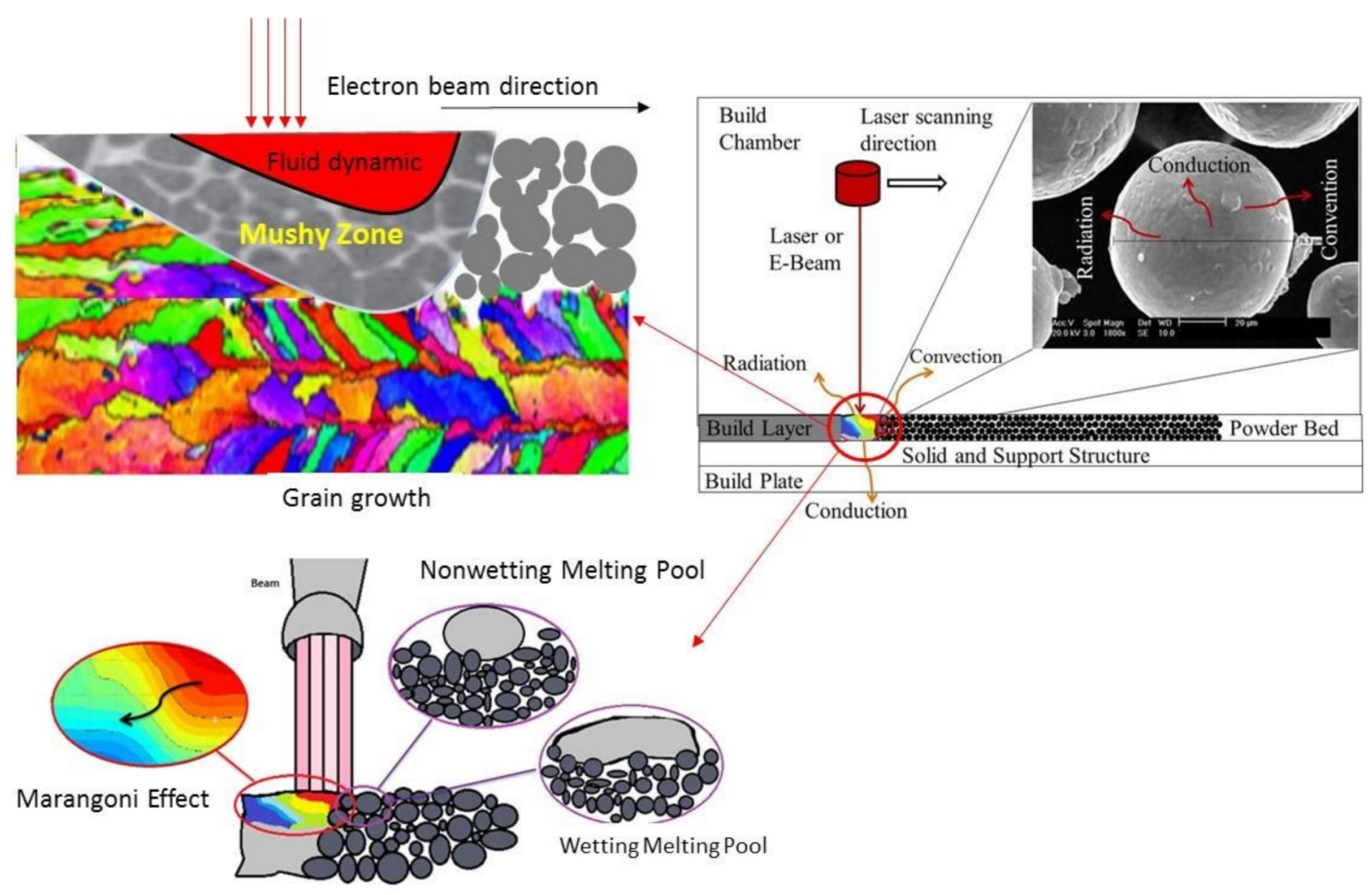

Figure 1. Physical phenomenon occurring during powder bed melting process of metallic materials.

This manuscript focuses on powder bed fusion technologies, its application in fabricating metallic materials and metallurgy of parts. Mechanical and corrosion behavior of parts produced using this technology is reviewed.

\section{Laser versus Electron Beam}

Electron beam melting was introduced to overcome some of the difficulties of using laser as heat source such as power and speed. Electron beam produces a much higher power ( $3000 \mathrm{~W}$ with current ARCAM technology vs. $400 \mathrm{~W}$ with current EOS technology $[5,11]$ ) and the beam speed can be much faster $(8000 \mathrm{~m} / \mathrm{s}$ in ARCAM vs. $7 \mathrm{~m} / \mathrm{s}$ in EOS [5,7-11]). 
These two characteristics result in a much shorter build time in EBM. Laser is currently used for both partial and full melting of material, whereas EBM is typically used only for full melting of material. Additionally, layer thickness is typically larger in EBM than in laser, which expedites the builds; however, this results in rougher surfaces and less dimensional accuracy. Build dimensions are similar in both technologies. The laser melting build chamber is at ambient pressure that is backfilled with an inert gas such as argon or nitrogen, whereas the EBM process is performed under vacuum with a partial pressure of helium [5,7-11]. EBM technology is much newer and is less explored, so there are a limited number of materials currently being fabricated using this technology. EBM has been successfully used for Ti and Ni alloys [12-24], while fabrication of other materials is still under investigation [25-29]. The other difference between EBM and laser technologies is that EBM typically uses a preheated build plate where temperature is kept relatively high for the duration of the build in order to keep the metal powder in place during the subsequent melting scan and decrease the thermal gradient in the build part [30]. However, laser uses a cold plate which can increase the heat extraction rate. Additionally, the heated plate in EBM will provide a longer time for microstructure to evolve due to many hours of aging at relatively high temperatures and assists in releasing the residual stresses. Therefore, parts produced using EBM technology typically experience slower cooling rate and lower residual stresses [31-33]. This results in a different microstructure formed during full melting and solidification in laser melting versus EBM [34]. Both techniques require high quality powder that is expensive and hard to produce. Additionally, the technology typically used for metals and ceramics is much more sophisticated than polymer technology. Due to the high melting temperature of metals and ceramics, these systems need to generate hundreds of watts of power. All of these translates into a very expensive technology that is very cost-prohibitive for many high-volume production companies [35,36]. Therefore, these machines are currently only being used for prototyping, custom-build parts and specific applications such as aerospace applications. Qualification and standardization are other major issues which need to be considered to fabricate industrial products [37].

\section{Process Parameters in Electron Beam and Laser Melting Methods}

One of the most interesting aspects of additive manufacturing and specifically powder bed technology is the ability to potentially control the final product through a bottom-up approach in which the microstructure and thus the properties of the final product can be controlled through the process by intelligently varying the process parameters. As the material is being built locally by melting and solidification of powder, the cooling rate and melt pool size can be varied by controlling process parameters such as beam power, beam speed, and powder layer thickness, etc. The final microstructure of the parts is also a function of other global level parameters such as build atmosphere, build orientation, scanning strategy and hatch spacing (spacing between two adjacent line that beam traces). Many researchers choose to combine parameters such as laser power, scanning speed, hatch spacing, and sometimes beam diameter, and quantify them into an overall variable referred to as the "volumetric energy density (VED)", "laser energy density," and sometimes the "linear laser energy density" [38-40]. The equations and variables for these parameters are listed below:

$$
\begin{gathered}
E=P /(v \times \delta) \\
\eta=P / v \\
\varepsilon=P /(v \times h \times d)
\end{gathered}
$$

Equation (1) is referred to the "laser energy density," where $E$ is the energy density in $\mathrm{J} / \mathrm{mm}^{2}, P$ is the laser power in $\mathrm{W}, v$ is the scan speed in $\mathrm{mm} / \mathrm{s}$, and $\delta$ is the hatch spacing in $\mathrm{mm}$ [38]. Equation (2) is known as the "linear energy density," where $\eta$ is the linear energy density in $\mathrm{J} / \mathrm{mm}, P$ is the laser power in $\mathrm{W}$, and $v$ is the scanning speed in $\mathrm{mm} / \mathrm{s}$ [39]. Equation (3) is referred to the "volumetric energy density," where $\varepsilon$ is volumetric energy 
density in $\mathrm{J} / \mathrm{mm}^{3}, P$ is the laser power in $\mathrm{W}, v$ is the scanning speed in $\mathrm{mm} / \mathrm{s}, d$ is powder layer thickness in $\mu \mathrm{m}$, and $h$ is hatch spacing in $\mu \mathrm{m}$ [40].

In addition to the process parameters, the powder feedstock quality has also a direct effect on the quality of the fabricated parts and repeatability of the process. Powder qualities are analyzed based on their intrinsic (e.g., composition, purity, and microstructure) and extrinsic (e.g., particle morphology, density, size distribution, and flowability) properties [41,42].

\section{Metals Used for Powder Bed Fusion Additive Manufacturing (PBF-AM)}

A critical issue in additively manufactured parts is whether consistent microstructure, mechanical, and corrosion properties can be achieved and whether the technology is competitive compared to the traditional technologies such as casting. In EBM and laser powder bed technology, melting and solidification occur locally, and cooling rate is a function of many other parameters such as beam power, beam speed, pre-heat conditions, geometry, hatch spacing, etc. Therefore, a variety of microstructures can be produced. A very great advantage is that microstructures can be controlled locally through the process if the effect of each parameter is well understood. There is less control over the process and many process parameters can affect the outcome. The fact that each layer is built with partial re-melting and solidification of the previous layer and heat extraction occurs in different manners for different geometries adds complexity to the process. The next sections of this manuscript summarize the literature findings on the effect of process parameters in EBM and laser melting processes on microstructure and properties of parts made of different metals/alloys such as $\mathrm{Ti}, \mathrm{Ni}$, Al alloys, steel, high entropy alloys (HEAs), and bulk metallic glasses (BMGs).

\subsection{Titanium (Ti) Alloys}

Ti metals and alloys have two types of crystal structures; body centered cubic (BCC) and hexagonal closed pack (HCP). BCC is called $\beta$ phase and it is stable in pure Ti only at temperatures above $\beta$ transus temperature. HCP crystal structure is called $\alpha$ phase. Ti-6Al-4V alloy is most heavily investigated material, due to its extraordinary properties and extensive use in biomedical and aerospace applications [1,43]. The isothermal phase diagram of Ti-6Al-4V composition indicates that both phases of $\alpha$ and $\beta$ exist at $800{ }^{\circ} \mathrm{C}$, but at $1000{ }^{\circ} \mathrm{C}$ only $\beta$ phase exists in Ti-6Al-4V [44]. Many different types of microstructures can be obtained through a controlled cooling rate [45]. A very slow cooling rate of Ti-6Al-4V alloy results in $\alpha$ phase globular in primary $\beta$ phase grain boundaries. Small increase in the cooling rate results in the formation of $\alpha$ platelets in primary $\beta$ phase grains [45]. The length of these platelets depends on the cooling rate. As cooling rate increases, at a certain level, a basket weave, Widmanstätten, type of microstructure forms. Quenching the material results in transformation of $\beta$ into martensitic type $\alpha$, either $\alpha^{\prime}$ with HCP crystal structure or $\alpha^{\prime \prime}$ with orthorhombic crystal structure [45]. The mechanical behavior of the alloy can be significantly varied by tailoring its microstructure [46]. For example, existence of globular $\alpha$ phase or platelets enhances the resistance to micro-crack development. The ductility, yield strength and crack propagation resistance are improved as the size of colonies of platelets decreases [47]. Plastic deformation in Ti-6Al-4V material at room temperature was found to be caused by planar slip in the $\alpha$ grains, at quasi-static strain rates, while at high strain rates deformation twinning is also observed [48]. Therefore, it is necessary to understand the effect of electron beam and laser processing parameter on microstructure and properties of these alloys.

4.1.1. Microstructure and Physical Properties of Powder Bed Fusion Additive Manufactured Ti Alloys

Electron Beam Processed Ti Alloys

There are several studies that have investigated the microstructure of EBM-built Ti-6A-4V sample compared to its wrought counterparts. EBM processed samples showed 
homogenous and primarily acicular $\alpha$-plate, with Widmanstätten pattern due to high solidification rate [1,49]. Dislocation density was slightly higher in EBM-fabricated samples than in the wrought products [1]. Ti-6Al-4V alloy fabricated using EBM presented a lamellar microstructure at the transverse direction, while it showed directional growth along the build direction and columnar microstructure due to higher thermal gradient in longitude direction [1]. A study conducted by Antonysamy [50] on Ti-6Al-4V displayed favored growth orientation along $<001>\beta$ normal to the build plate. It was also found that the grain orientation depends on the sample thickness. In specimens built with larger thickness, the grains were more oriented in the $<001>$ direction, whereas in smaller thickness, more random orientation was observed. Columnar growth of the $\beta$ grains was observed by several other scientists, including Cormier et al. [51]. This group compared the microstructure of thin-walled structures with bulk Ti-6Al-4V and observed the columnar growth in both cases. The fact that the growth spanned over several layers suggested that the material was kept at temperatures higher than $\beta$ transus temperature during build. Anisotropic behavior as shown by Ladani et al. [52] is expected to be caused by the columnar grain growth in these materials. A comprehensive study conducted by Safdar et al. [53-56] also confirms the columnar grain growth. In an interesting investigation of scanning length as beam rosters over powder, they found that increasing scanning length on a trace results in coarser $\beta$ grains. The built-in function in the ARCAM machine typically reduces the speed of the beam as it turns. Therefore, Safdar et al. [53-56] made a hypothesis that as beam turns, its speed is reduced and therefore the energy density is reduced. In short scan lengths, this portion of the build contributes significantly to the total length and therefore the total energy density is reduced which causes the grain sizes to increase. Cormier et al. [51] also observed that the size of $\alpha$ platelets in thin-walled samples were one third of those in bulk samples. This was attributed to the higher cooling rate in thin-walled samples. A similar observation was made by Ladani et al. [52,57], where finer morphology was observed in sample regions close to the build table compared to the regions away from build table. As it got nearer to the bottom, the $\alpha$-plate became finer and more similar to a lamellar microstructure rather than acicular. This change in microstructure was attributed to variation in the heat transfer rate from the bottom to the top of the specimen which caused the variation in microstructure through specimen height and consequently the variation in properties [58]. Faster cooling rates closer to the build table leads to finer microstructure [1,57].

Different types of defects such as un-sintered powders or voids were found in EBM parts [59]. Increase in electron energy density led to increase in the width of prior- $\beta$ grains as well as reducing defects such as pores and un-melted particles [60]. Extensive research on EBM technique, parts quality, types of defects, effect of process parameter on defects, and microstructure of material produced using this technique was conducted by Murr et al. $[22,28,58,61-67]$. The resulting part quality from EBM produced parts is directly related to the input energy density in the melt pool and the length of the scan line [68]. Juechter et al. [69] used a different criteria and approach to evaluate the quality of parts. They based their analysis on relative density of $99.5 \%$ and smooth top surface finish. A process window was developed based on line energy density as defined in Equation (2) in this manuscript and scanning speed. The process window became narrower at higher scanning speed. Higher line energy densities resulted in an uneven top surface and reduced aluminum content. There is a critical amount of line energy density which is required to achieve the required density. Increasing scanning speed reduces the line energy density. In their analysis, they distinguished between the local heat loss, which is the result of interaction of the beam with power locally, and heat loss during hatching, which is the time frame within which the beam returns to the point during hatching. Based on this analysis, Juechter et al. developed a plot which depicts the minimum energy density and scanning speed required to achieve dense Ti-6Al-4V parts.

A study conducted on Ti-47Al-2Cr-2Nb by Ge et al. [70] found that higher beam current resulted in more loss of aluminum from the original composition. At $10 \mathrm{~mA}$, there 
was a $15 \%$ loss of aluminum. The resulting microstructure also showed a variance with the beam current. The lower beam current resulted in a fine lamellar $\alpha_{2}$-phase structure, whereas the higher beam current samples had columnar $\beta$-grains with needle $\alpha_{2}$-phase within the $\beta$-phase. Schwerdtfeger et al. [71] investigated a large parameter envelope for this alloy to determine the robustness of the process in achieving the proper microstructure formation. The build temperature was kept at a temperature of $\sim 950{ }^{\circ} \mathrm{C}$, so that once the build cools there is only a transition from $\alpha$ to $\alpha_{2}$. There was a direct relationship of line energy and beam current to the loss of aluminum in the alloy. With a layer thickness of $100 \mu \mathrm{m}$, increasing the line energy from $0.7 \mathrm{~J} / \mathrm{mm}$ to $1.1 \mathrm{~J} / \mathrm{mm}$ by altering the beam current and scan speeds leads to a 1-4 at.\% Al loss. At constant line energy, increasing the beam current from 3.5 to $10.5 \mathrm{~mA}$ increased the $\mathrm{Al}$ loss by 1 at.\%. Lowering the layer thickness to $70 \mu \mathrm{m}$ and decreasing the hatch line offset resulted in a much lower line energy necessary to achieve fully dense parts and gave a much broader processing window. Having the lower beam power also led to a reduction in over melting and $\mathrm{Al}$ vaporization. The lowest Al loss was measured to be only 0.5 at.\%. In [63], samples were built via EBM from Ti-47Al$2 \mathrm{Cr}-2 \mathrm{Nb}$ powder which resulted in a two phases lamellar structure of $\gamma$-TiAl and $\alpha_{2}-\mathrm{Ti}_{3} \mathrm{Al}$ after processing. The characteristics of the Ti- $48 \mathrm{Al}-2 \mathrm{Cr}-2 \mathrm{Nb}$ alloy are dependent on the $\gamma$-TiAl phase, thus significant Al losses from vaporization during EBM processing inhibit the formation of the gamma phase.

The microstructure of Ti-55511 alloy fabricated using EBM is made up of columnar prior- $\beta$ grains, zigzag grain boundary ( $\alpha \mathrm{GB})$, coarse $\alpha_{1}$ colony and fine basket-wave $\alpha_{2}$ with high density of dislocations, while the forged Ti-55511 alloy showed the bi-modal microstructures with spherical $\alpha$ phase after heat treatment [72]. The preheating process by electrons during EBM offers an in situ heat treatment on the formed parts to acquire the desired microstructures. The effect of substrate temperature and electron energy density on microstructure of EBM-built Ti-55511 alloy was investigated. It was reported that as the building temperature and electron energy density increased, it led to the coarsening of the prior- $\beta$ columnar grains, while the content of the residual $\beta$ phase was not changed. Increasing building temperature from $650{ }^{\circ} \mathrm{C}$ to $750{ }^{\circ} \mathrm{C}$ also improved precipitation of fine $\alpha_{2}$ from less than $10 \%$ to more than $50 \%$ and inhibited the formation of $\alpha_{1}$ from $\sim 30 \%$ to less than $2 \%$; however, the total $\alpha$ phase $\left(\alpha_{1}\right.$ and $\left.\alpha_{2}\right)$ was unchanged [60]. In addition to the volume fraction of $\alpha_{1}$ and $\alpha_{2}$, the building temperature plays a crucial role in determining their sizes. $\alpha_{1}$ became 1.9 times coarser with increase in substrate temperature, however the width of $\alpha_{2}$ went down [60].

\section{Laser-Processed Ti Alloys}

Laser parts are expected to experience higher cooling rates which could result in a more refined microstructure [67] or in some case even stress cracks developed due to rapid shrinkage of the materials. Extensive research has been conducted on Ti-6Al-4V [73-79]. It was reported that the Ti-6Al-4V alloy fabricated using SLM showed a microstructure full of $\alpha^{\prime}$-martensite [80], whereas those built using the EBM exhibited lamellar $\alpha$ and $\beta$ phases decomposed by $\alpha^{\prime}$-martensite due to substrate preheating, which leads to in situ heat treatment and relatively low cooling rate [68]. A martensite, or needle-like $\alpha$ phase was formed between $\beta$ phases during the rapid cooling of the laser melting process $[73,74]$. Slower cooling rates resulted in the formation of a more stable $\alpha$ and $\beta$ phases combination $[75,76]$. It was shown that denser parts were produced when higher powers and thus lower cooling rates were used [77,78]. Ti-6Al-2Sn-4Zr-6Mo alloy built using laser PBF-AM showed prior- $\beta$ grains, characterized by a columnar morphology and a completely martensitic microstructure which is orthorhombic $\left(\alpha^{\prime \prime}\right)$. A different processing parameter was applied to fabricate Ti-6Al-2Sn-4Zr-6Mo alloy and results showed that minimization of porosity and pores morphology closer to sphericity was achieved more efficiently at a higher amount of VED. In addition, higher VED values led to finer $\alpha^{\prime \prime}$ needles in the as-built condition [81]. 
Several studies were dedicated to understand the scanning strategy on the final microstructure and part quality $[76,77,82,83]$. Similar microstructure was found when the scanning strategy was changed from sequential scan in between the previous scan lines to offsetting the scan vectors by $50 \%$ on each subsequent layer [77]. Part density was found to be fairly similar in a study conducted with several different scan patterns [76]. Nevertheless, hatch spacing was found to have maximum effect [76]. The best microstructure was produced using a "cross hatching scan with zigzag scan vector" used by [82]. It was reported that fully dense plate can be achieved when the hatch spacing was less than the laser diameter and the ratio of laser power to scanning speed was larger than 0.5 [1].

Selective laser melting processed parts are typically subjected to heat treatment. The main reason for this is the larger residual stresses that develop in these parts due to the lack of a heated plate. The effect of heat treatment on microstructure of alloys after laser processing was also studied. It was found the martensitic $\alpha$ microstructure can transform into $\alpha$-Ti. The fraction of $\beta$ decreased as well as grain size increased after heattreated or hot isostatic presses (HIPed) [84]. In situ heat treatment was also introduced for fabrication of Ti-5553 using SLM. This heat treatment promoted the formation of finely dispersed $\alpha$-phase plates [85]. Polozov et al. [86] studied the effect of preheating on laser processing of orthorhombic Ti alloys. They found the crack-free samples using platform preheating temperatures of $600{ }^{\circ} \mathrm{C}$ and higher. The chemical homogeneity of the samples enhanced with an increase in preheating temperature. Fine cellular microstructure consisting of the $\mathrm{B}_{2} / \beta$ phase can be obtained at preheating temperatures of $200{ }^{\circ} \mathrm{C}$ and $500{ }^{\circ} \mathrm{C}$, while increasing preheating temperature to $600-900{ }^{\circ} \mathrm{C}$ led to the formation of an O-phase with a different morphology and volume fraction [86]. Figure 2 shows the effect of laser processing parameters, namely preheating temperature and volume energy density on the relative density of the produced samples using the mechanically alloyed plasma spheroidized (MAPS) Ti-22Al-22Nb-0.1Mo-0.3Hf-0.3Ta-1.5Zr-0.8Si-0.9Fe (at.\%) (Figure 2a) and gas atomized (GA) Ti-24Al-25Nb-1Zr-1.4V-0.6Mo-0.3Si (at.\%) (Figure 2b) powders. Increasing the preheating temperature to $700{ }^{\circ} \mathrm{C}$ and volume energy density to $77.8 \mathrm{~J} / \mathrm{mm}^{3}$ led to an increase in the relative density to $99.3 \pm 0.1 \%$ for the MAPS samples. GA powders showed relatively higher density above $99 \%$ than MPAS powders (Figure 2 b). The highest density of $99.9 \%$ can be achieved at volume energy density of 45.8 and $54.9 \mathrm{~J} / \mathrm{mm}^{3}$ and preheating temperature of $600{ }^{\circ} \mathrm{C}$ and $700{ }^{\circ} \mathrm{C}$. A further increase in temperature resulting in a lower density may be due to melt pool overheating. Figure $2 \mathrm{c}, \mathrm{d}$ show the process map confirming that two parameters at preheating temperature of $700{ }^{\circ} \mathrm{C}$ can result in relative density more than $99 \%$ for MPAS powder and three parameter sets allowed attaining relative density higher than $99.9 \%$ for GA powders (green symbols in Figure 2c,d) [86].

\subsubsection{Mechanical Properties of Powder Bed Fusion Additive Manufactured Ti Alloys Electron Beam Processed Ti Alloys}

It was found that the Ti parts built using EBM can present a combination of good ductility and excellent fracture strength comparable to best wrought material which satisfies the ASTM standards. Their excellent properties are attributed to a high solidification rate and acicular morphology [1,49,58]. Hrabe et al. [33] reported the fatigue strength of EBMbuilt Ti-6Al-4V alloy to be in the range of 200-250 $\mathrm{MPa}$ at $10^{7}$, cycles which increased to 550-600 $\mathrm{MPa}$ at the same cycles after HIP due to a reduction in voids and porosity. Mian et al. [15] predicted the fatigue properties of Ti-6Al-4V using surface roughness, hardness, internal, and external defect parameters and applying Murakami's square root of area parameter and Basquin's models. They found the external defects to be more dominant than the internal defects in determining the critical fatigue limit for as-built EBM AM parts. They also studied the effect of temperature on EBM-built Ti-6Al-4V alloy at different building orientations showing softening of all samples as temperature increased due to increase in dislocation mobility and grain coarsening [16]. Extensive microstructural analysis and hardness testing was conducted for Ti-24Nb-4Zr-7.9Sn fabricated using EBM by Hernandez et al. [66]. The measured value of hardness was found to conflict with the 
observed microstructure. However, the average value of hardness was found to be higher than parts built using laser melting process.
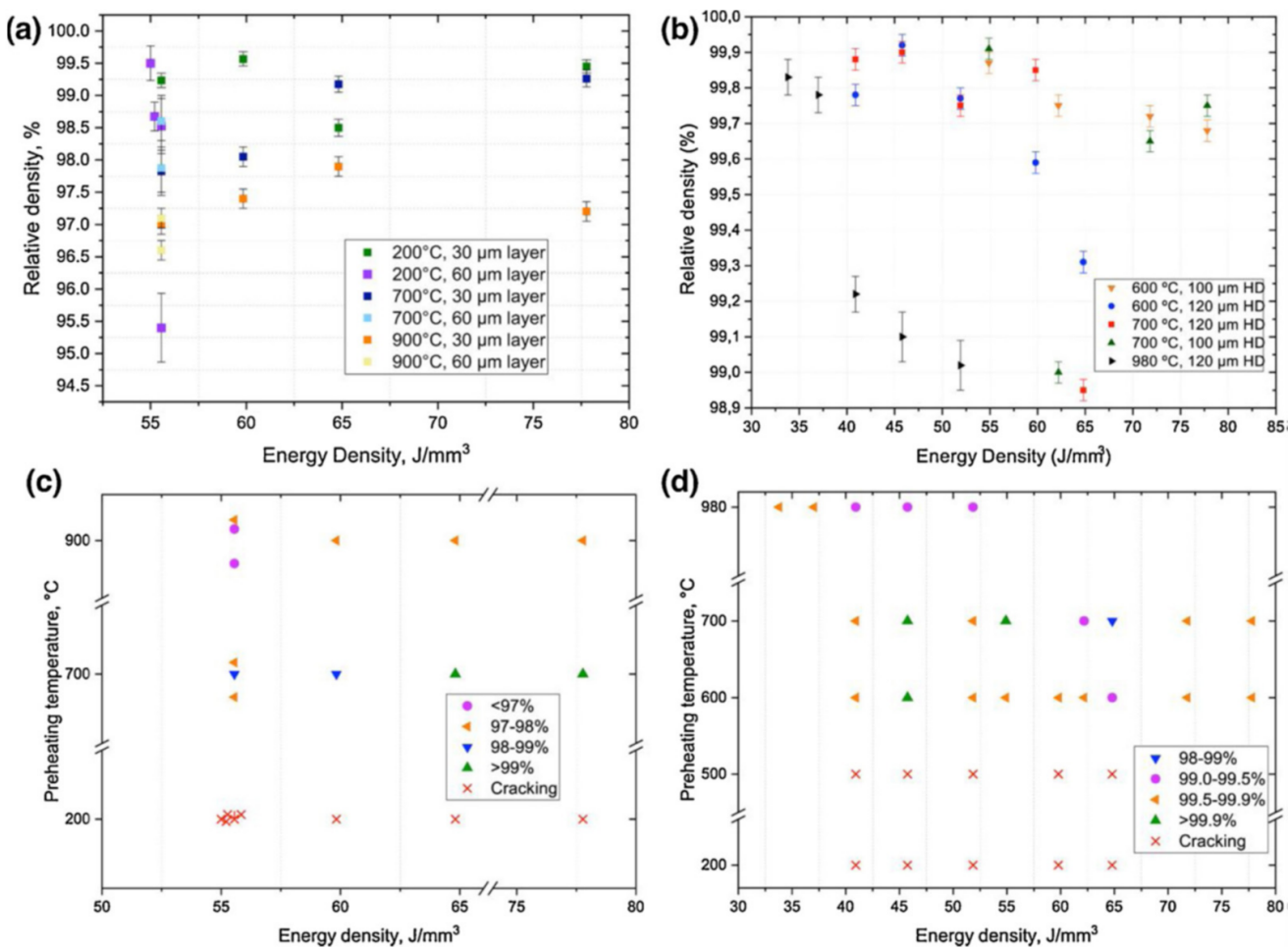

Figure 2. Relative density as a function of volume energy density and preheat substrate temperature for laser-processed samples from (a) mechanically alloyed plasma spheroidized (MAPS) and (b) gas atomized (GA) powders; and process maps relating preheating temperature of substrate and volume energy density for the samples from (c) MAPS and (d) GA powders. Reprinted with permission from ref. [86]. Copyright 2021 Elsevier.

As was reported in previous section, the processing parameter can significantly change the microstructure which subsequently may affect mechanical properties. The engineering stress-strain plot of EBM-built Ti-55511 is shown in Figure 3 [60]. In this figure, A-E102 and B-E102 were designated for samples with electron energy density of $102 \mathrm{~J} / \mathrm{mm}^{3}$ and substrate temperature of $650{ }^{\circ} \mathrm{C}$ and $750{ }^{\circ} \mathrm{C}$, respectively. The energy density was $51 \mathrm{~J} / \mathrm{mm}^{3}$ for A-E51 and B-E51 samples and their substrate temperature was $650{ }^{\circ} \mathrm{C}$ and $750{ }^{\circ} \mathrm{C}$, respectively. It can be seen that the tensile strength of the alloy increased, whereas the elongation decreased as the energy input and substrate temperature increased. The increase in tensile strength was associated with the microstructural change and enhancement in the volume fraction of $\alpha_{2}$ in terms of boundary strengthening [60].

The changes in the mechanical properties relative to distance from build plate were evaluated in an experiment conducted at NIST [87]. Even though the EBM samples showed a measurable change in $\alpha$ platelets' thickness as the distance from build plate increased [57], the tensile test did not show significant variations in mechanical behavior as a function of distance from the base-plate. This study only conducted the measurements up to $25 \mathrm{~mm}$ distance from build plate. The analysis conducted by Ladani et al. [57] was on specimens at $100 \mathrm{~mm}$ distance from the build table. In another study conducted by the same group, part orientation, melt pool size and location of the part was investigated [88]. Contradictory to the previous studies $[50,57]$ which showed the preferential growth orientation along the build direction and anisotropy in mechanical properties, this study did not show significant anisotropy in ultimate tensile strength (UTS) and yield strength (YS). In contrast to the findings of Ladani et al. [16,57], which showed more ductility along the build direction, this study found $30 \%$ less ductility in that orientation. Both studies showed lower hardness 
in vertically built parts. This indicates that local mechanical properties may vary through the parts. The global behavior is usually somehow affected by the local properties (e.g., large local defects or weaknesses may cause premature failure of the parts).

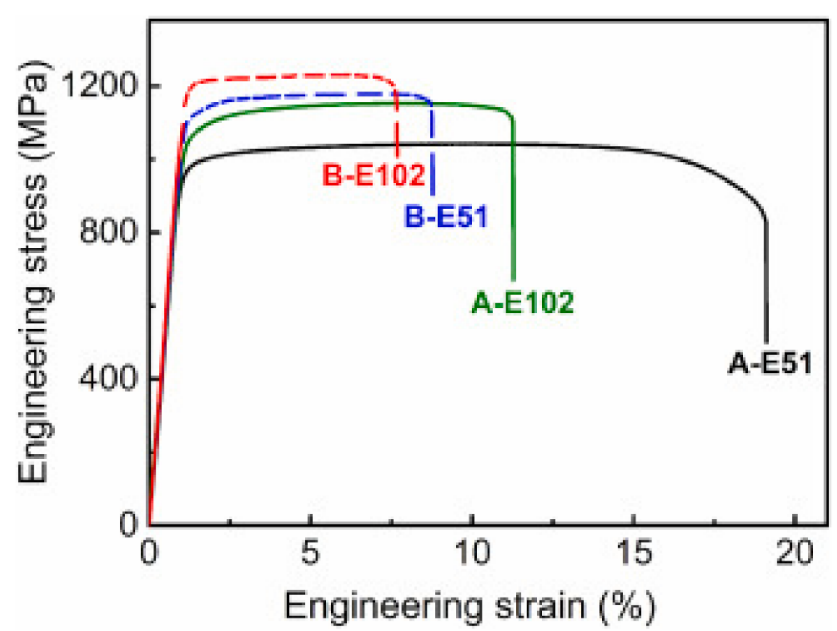

Figure 3. Engineering stress-strain plot for EBM-built Ti-55511 at different process parameters. A-E51: electron energy density $51 \mathrm{~J} / \mathrm{mm}^{3}$ and substrate temperature $650{ }^{\circ} \mathrm{C}$; A-E102: electron energy density $102 \mathrm{~J} / \mathrm{mm}^{3}$ and substrate temperature $650{ }^{\circ} \mathrm{C}$; B-E51: electron energy density $51 \mathrm{~J} / \mathrm{mm}^{3}$ and substrate temperature $750{ }^{\circ} \mathrm{C}$; B-E102: electron energy density $102 \mathrm{~J} / \mathrm{mm}^{3}$ and substrate temperature $750{ }^{\circ} \mathrm{C}$. Reprinted with permission from ref. [60]. Copyright 2021 Elsevier.

\section{Laser-Processed Ti Alloys}

It has been found in the literature that laser parts exhibited slightly higher strength, but lower hardness than EBM-built parts [67]. the Ti-6Al-4V alloy fabricated using SLM showed higher yield strength, ultimate strength, fatigue life and fracture strength; however, it also showed the lowest value of ductility compared to its counterparts fabricated using EBM and other AM processes [1,89]. Other studies focused on effect of build orientation in laser melting process on the final microstructure and mechanical properties $[74,83,89,90]$. The same phenomenon of perpendicular grain growth in the direction of build is observed in laser, and parts show anisotropic behavior with higher strengths, but lower ductility for parts tested perpendicular to the build direction $[83,89,90]$. As the grain growth orientation is very similar to EBM process, the same hypothesis of anisotropy can perhaps be implemented here in this technology. Build orientation was investigated in a lattice structure in [84]. In this study, both the cell orientation and build orientation were varied.

The effect of processing parameter on mechanical properties of laser-processed $\mathrm{Ti}_{45} \mathrm{Al}_{5} \mathrm{Nb}_{0.5} \mathrm{Si}-(\mathrm{xTiC})(\mathrm{x}=0,5$, and 10) composites was studied. Nanohardness increased with increase in power for all $\mathrm{Ti}_{45} \mathrm{Al}_{5} \mathrm{Nb}_{0.5} \mathrm{Si}_{1} \mathrm{Ti}_{45} \mathrm{Al}_{5} \mathrm{Nb}_{0.5} \mathrm{Si}-5 \mathrm{TiC}$ and $\mathrm{Ti}_{45} \mathrm{Al}_{5} \mathrm{Nb}_{0.5} \mathrm{Si}-10 \mathrm{TiC}$ alloys (Figure 4a). Increase in scanning speed from 200 to $400 \mathrm{~mm} / \mathrm{min}$ increased nanohardness of $\mathrm{Ti}_{45} \mathrm{Al}_{5} \mathrm{Nb}_{0.5} \mathrm{Si}$ and $\mathrm{Ti}_{45} \mathrm{Al}_{5} \mathrm{Nb}_{0.5} \mathrm{Si}-10 \mathrm{TiC}$ laser-built alloys. For $\mathrm{Ti}_{45} \mathrm{Al}_{5} \mathrm{Nb}_{0.5} \mathrm{Si}-5 \mathrm{TiC}$, nanohardness initially decreased with the increase in scan speed from 200 to $300 \mathrm{~mm} / \mathrm{min}$, and then increased with further the increase in speed to $400 \mathrm{~mm} / \mathrm{min}$ (Figure $4 \mathrm{~b}$ ). The increase in powder feed rate showed a slight increase in nanohardness of all alloys (Figure 4c) [91]. In another study, higher power and lower scanning speed (i.e., higher VED) in laser powder bed fusion AM of Ti-6Al-2Sn-4Zr-6Mo alloy led to higher hardness may be attributed to formation of finer $\alpha^{\prime \prime}$ needles in this alloy [81]. 

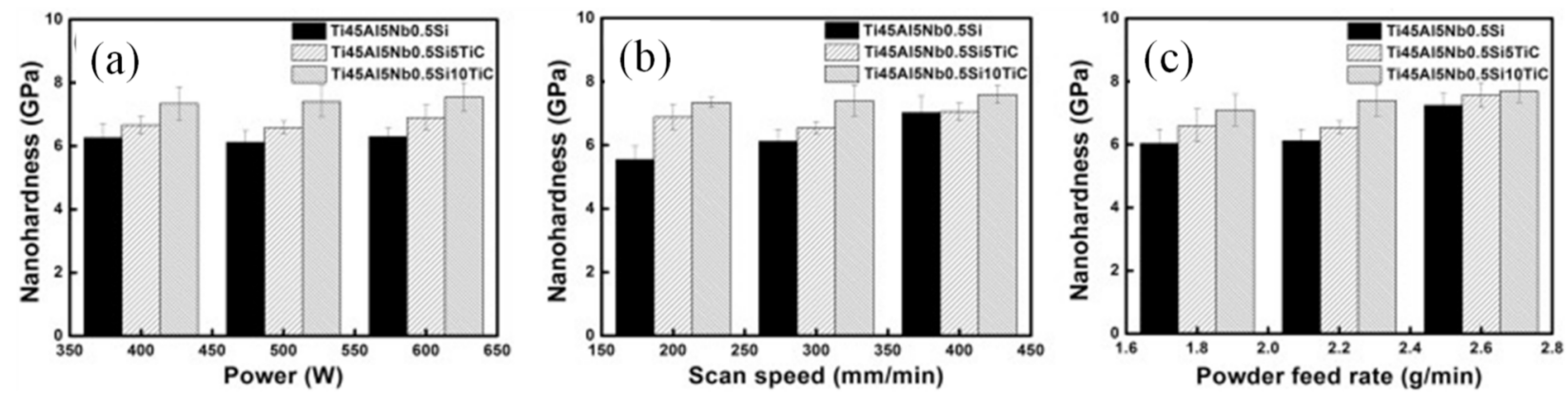

Figure 4. Nanohardness of laser-processed Ti45Al5Nb0.5Si-xTiC ( $x=0,5$, and 10) composites as a function of (a) power, (b) scan speed, and (c) powder feed rate. Reprinted with permission from ref. [91]. Copyright 2021 Elsevier.

Many different heat treatments were investigated in the reviewed literature, where it was generally found that post-SLM heat treating reduced the yield and ultimate stresses of parts $[74,90]$, improved fracture toughness and high cycle fatigue crack growth resistance $[75,84,90]$, and decreased porosity from the re-melting and redistribution of material [83]. The tensile strength of SLM-built Ti-5553 was improved using in situ heat treatment as a result of formation of fine $\alpha$-phase plates [85]. In a study carried out by Igor Polozov et al. [86], the highest microhardness and the highest tensile strength values were obtained using $700{ }^{\circ} \mathrm{C}$ and $980^{\circ} \mathrm{C}$ substrate preheating temperature, respectively. Powders prepared with different methods also showed different properties due to the difference in their microstructure. Samples fabricated using GA powders showed higher microhardness than the samples prepared using MPAS powders with almost similar composition [86].

\subsubsection{Corrosion Behavior of Powder Bed Fusion Additive Manufactured Ti Alloys}

The corrosion behavior of several PBF-AM processed Ti alloys were studied [92-102].

\section{Electron Beam Processed Ti Alloys}

The EBM-produced Ti-6Al-4V showed better corrosion properties than its traditional wrought counterpart [101]. The polarization study of EBM-produced Ti-6Al-4V showed slightly smaller corrosion current density than that of wrought ones in phosphate-buffered saline (PBS) solution, and the passivation current density was also higher compared to the wrought ones, but with a negligible difference. Electrochemical impedance spectroscopy (EIS) results also showed the better corrosion resistance of the EBM sample compared to its wrought counterpart. EBM-produced samples displayed different polarization behavior at different building angles in $1 \mathrm{M}$ hydrochloric $(\mathrm{HCl})$ solution [92]. The corrosion resistance decreased by the following order of building angles: $0^{\circ}>55^{\circ}>90^{\circ}>45^{\circ}$. Figure 5 shows the morphology of EBM-processed samples at different building angles before (raw a) and after (raw b) corrosion test at $1 \mathrm{M} \mathrm{HCl}$. A significant amount of porosity was observed at $45^{\circ}$, confirming its highly corrosivity in the $\mathrm{HCl}$ solution. The $0^{\circ}$ sample showed a few scattered pits on the micro-morphology, confirming its better corrosion resistance. The number of pits in other samples were also consistent with polarization test results and are attributed to the grain boundary density. EBSD results showed the magnitude of grain boundary as the order of $45^{\circ}>90^{\circ}>55^{\circ}>0^{\circ}$ [100]. 
(a)
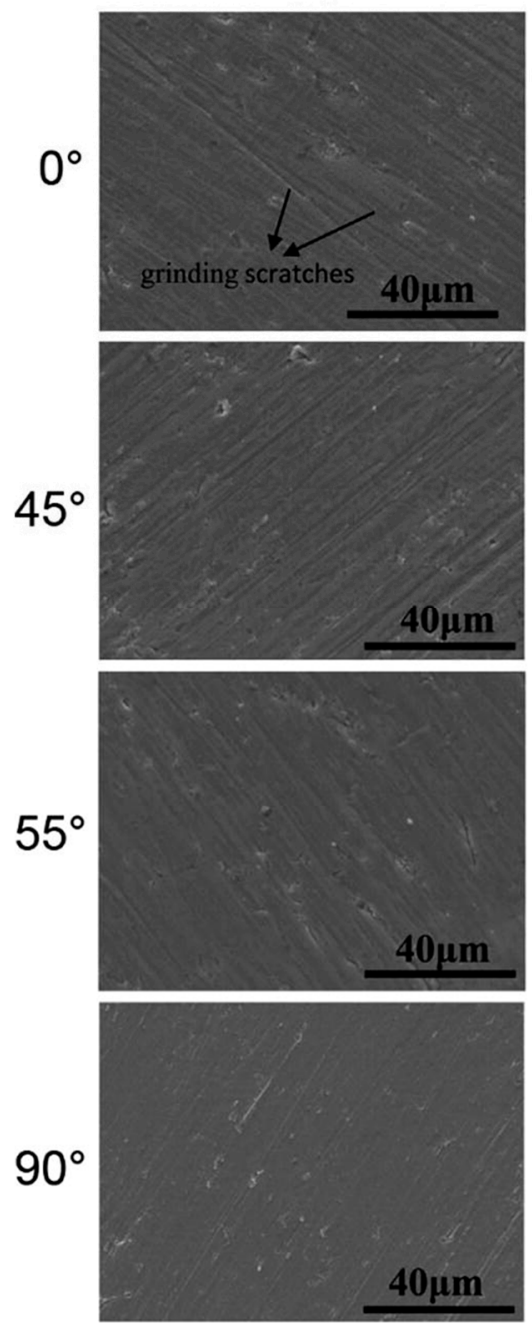

(b)
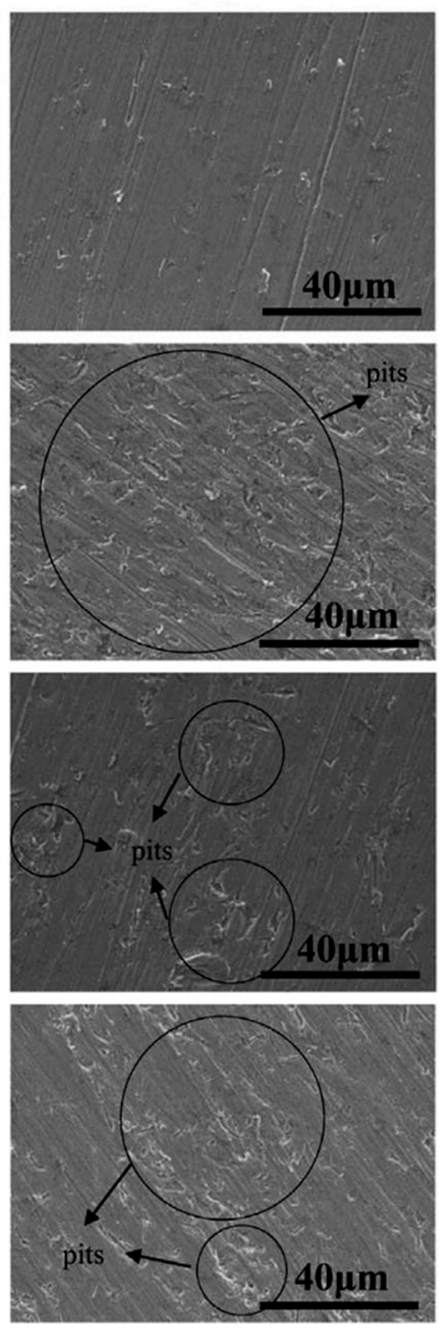

Figure 5. Surface morphology of EBM-built Ti-6Al-4V with different building planes in $1 \mathrm{M} \mathrm{HCl}$ solution (a) before corrosion test, and (b) after corrosion test. Reprinted with permission from ref. [92]. Copyright 2021 Elsevier.

Laser-Processed Ti Alloys

It was found that the $\alpha$ phase of Ti- $6 \mathrm{Al}-4 \mathrm{~V}$ produced by SLM has a high energy state, which is detrimental for its corrosion resistance, and the corrosion occurs preferentially on the needle-like $\alpha$ phase [97]. Due to $\mathrm{V}$ element in the $\beta$ phase, it can be sustained in a corrosive environment and the $\mathrm{Ti}_{2} \mathrm{O}$ oxide film which is formed on $\beta$-phase is more stable than that in the $\alpha$ phase $[100,102]$. Therefore, the commercial Grade 5 alloy which has a relatively large $\beta$-phase content (13.3\%) showed superior corrosion resistance to the SLM-built Ti alloy with lower $\beta$-phase content (5\%) [96-98]. The open circuit potential (OCP) was stabilized for Grade 5 alloy at the time of $25 \mathrm{~h}$, but the stabilizing time was $50 \mathrm{~h}$ for SLM-produced alloy in a $3.5 \mathrm{wt} . \%$ sodium chloride $(\mathrm{NaCl})$ solution and a slightly higher OCP value of SLM-produced Ti-6Al-4V was observed. The potentiodynamic polarization curves of SLM-produced Ti-6Al-4V and Grade 5 alloy in $3.5 \mathrm{wt} . \% \mathrm{NaCl}$ solution presented a pronounced passivation area for both alloys. The passivation current density of the Grade 5 alloy was $0.39 \mu \mathrm{A} / \mathrm{cm}^{2}$, compared to $0.84 \mu \mathrm{A} / \mathrm{cm}^{2}$ for SLM-produced Ti-6Al-4V, representing its better passivation ability. In addition, the higher breakdown potential for Grade 5 alloy was found indicating that the alloy can maintain the passivation zone, and it is difficult for it to be broken down or dissolved by halide ions [97]. The corrosion behavior 
for SLM-produced Ti alloy at different manufacturing planes (XY plane and XZ plane) was also studied in $3.5 \mathrm{wt} . \% \mathrm{NaCl}$ and $1 \mathrm{M} \mathrm{HCl}$. The results showed that the passivation region started at same potential for all tests; however, it was smaller in sodium chloride solution than that in hydrochloric acid solution. Moreover, the passivation current densities of the $\mathrm{XY}$ and $\mathrm{XZ}$ planes were $0.76 \mu \mathrm{A} / \mathrm{cm}^{2}$ in the sodium chloride solution and were $1.78 \mu \mathrm{A} / \mathrm{cm}^{2}$ and $2.81 \mu \mathrm{A} / \mathrm{cm}^{2}$ in the hydrochloric acid solution, respectively, indicating the superior corrosion resistance of the $\mathrm{XY}$ plane than that of the $\mathrm{XZ}$ plane [96].

The effect of heat treatment on corrosion behavior of PBF-AM of Ti alloys was also studied. Results showed that all the heat-treated SLM-produced Ti-6Al-4V samples had a larger corrosion current density than the un-treated sample and the corrosion behavior exhibited a decreasing trend as the heat treatment temperature increased [100]. Yang et al. [94] studied the effect of various AM technologies (i.e., Wire and arc additive manufacturing (WAAM), SLM, and rolling) and heat treatment ( $\mathrm{HT} 1$ at $750{ }^{\circ} \mathrm{C}$ and $\mathrm{HT} 2$ at $1020^{\circ} \mathrm{C}$ ) on corrosion behavior of Ti-6Al-4V at $3.5 \mathrm{wt}$. $\% \mathrm{NaCl}$. WAAM showed nobler corrosion potential than the other samples, which may be attributed to its higher level of $\alpha$ phase, which is nobler than $\beta$ and $\alpha$ phases. The corrosion current densities of samples produced by WAAM, rolling, and SLM + HT1 are nearly two orders of magnitude lower than those by SLM and SLM + HT2. SLM + HT2 showed the highest corrosion current density, whereas SLM + HT1 exhibited the lowest. The corrosion rate was in the order of: SLM + HT1 < rolling $<$ WAAM $<$ SLM $<$ SLM + HT2. Pitting corrosion was reported to be the main mechanism of corrosion failure. The SLM + HT1 sample showed the minimum passive current density and pitting potential, while SLM + HT2 had the maximum passive current and pitting potential, suggesting the sensitivity of corrosion resistance of SLMed Ti-6Al-4V sample to heat treatment. According to potentiodynamic experiments, the decreasing order of corrosion resistance of the samples is as follows: SLM + HT1 > rolling > WAAM > SLM $>$ SLM + HT2. The greater corrosion resistance of the SLM + HT1 sample is associated with its less corrosion current density, passive current density, passive potential, and a nobler corrosion potential.

\subsection{Nickel (Ni) Alloys}

In comparison to $\mathrm{Ti}$, using EBM and a laser melting process to produce Ni parts has been investigated less intensively. $\mathrm{Ni}$ is mostly investigated in the form of Inconel (between $32-72 \%$ of $\mathrm{Ni}$ and around $14-25 \% \mathrm{Cr}$ with small amount of other elements such as $\mathrm{Fe}, \mathrm{Al}, \mathrm{Ti}$, Mo, etc.), as it is often used for aerospace applications. Inconel typically consists of $\gamma$ matrix with a face-centered cubic crystal structure that contains a large amount of strengthening phases, including ordered face-centered cubic $\gamma^{\prime}$, ordered tetragonal $\gamma^{\prime \prime}$, orthorhombic $\delta$, tetragonal $\sigma$, and hexagonal Laves phases $[103,104]$. The strengthening mechanism in this material is through formation of $\gamma^{\prime}$ and $\gamma^{\prime \prime}$ precipitates. The Laves phase is detrimental to the performance of Inconel because it reduces the amount of free $\mathrm{Nb}$ in the system and allows less $\gamma^{\prime \prime}$ to form, and it has a lower melting temperature than the other phases in Inconel [105]. Inconel alloys are resistant to corrosion and oxidation and are highly suitable for extreme environments such as high temperatures and high pressures. The fabrication of Inconel alloys using powder bed technology is of particular interest, mainly because it is very difficult to shape or machine.

\subsubsection{Microstructural Characterization of Powder Bed Fusion Additive Manufactured Ni Alloys \\ Electron Beam Processed Ni Alloys}

Numerous studies have examined the microstructure of EBM-AM-built Inconel 718 (IN718) in as-deposited and post-heat-treated conditions [31,104,106-115]. Different microstructures were reported for this alloy using different scanning strategies. Although contour scanning resulted in heterogeneous grain morphologies with weak texture, the hatch scanning lead to mainly columnar grains microstructure with epitaxial growth in the build direction [112,116-118]. The columnar grains of EBM processed IN718 displayed a 
very strong $\{100\}$ texture along the building direction, which was retained even after postprocessing [112,117]. Precipitates in the as-built IN718 alloy included $\gamma^{\prime}, \gamma^{\prime \prime}, \delta$, TiN and $\mathrm{NbC}$ [112]. The alloy built using a contour scanning strategy showed a higher density of fine carbides than the one fabricated using the hatch scanning strategy; the difference is negligible after appropriate heat treatment [119]. An increase in grain width and precipitation coarsening was found as the distance from build table increased $[109,116]$. Interestingly, it was found that beam focus has an effect on the degree to which the grains grow in a columnar manner. As the beam focus is reduced, the beam spread is increased with the same energy. This results in less penetration depth and less melting of the solid layer below the powder, which could result in reducing the epitaxial effect and deviation from columnar growth [120]. A more focused beam was found to result in a better columnar grain growth [116]. As stated previously, defects are an issue in as-built samples, which need to be considered for their structural applications. Goel et al. [117] showed that postprocessing of EBM-built IN718, such as hot isostatic pressing (HIP), led to a reduction in defects, and through appropriate selection of HIP temperature grain size, growth can be avoided.

\section{Laser-Processed Ni Alloys}

The effect of laser processing and post-processing parameters on quality, microstructure and mechanical behavior of $\mathrm{Ni}$ alloys built using the laser melting technique has been investigated heavily including Inconel 718 [39,107,121-139], Inconel 625 [140-145], Inconel 935 [146], Inconel 713LC (IN713LC) [147], and Inconel 738 [148]. Voids are more common in laser melting processes since inert gases are used inside the chamber. A similar microstructure was observed in these materials as columnar grains were formed in the direction of the build, which were more pronounced with the increase in the laser focus and power [131]. Figure 6a shows a 3D EBSD image of the as-built IN713LC confirming the columnar structure of the grains on the side with a build direction growth orientation. However, the top surface shows equiaxed grain structure. Heat treatment of as-built IN713LC at elevated temperature led to the coarsening of the grains, as shown in Figure 6b [147]. High laser powers to fabricate Inconel, can result in formation of Laves as well as increasing formation of voids or pore in the material [131]. One phenomenon that can be observed at relatively low scanning speeds, or at speeds where insufficient energy is applied to the build part, is the formation of discontinuous scan tracks, large-sized balls, and round open pores which can cause the re-coater blade to jam and cause the build to fail $[40,140,149]$. Similar effects such as increase density due to increase laser power and better surface finish in lower scan speeds were observed in parts built using laser [132]. One notable difference in microstructure was the variation observed by Jia et al. [39,40]. In their work, as energy density increased, the microstructure transformed from coarsened columnar dendrites, to severely clustered dendrites, and eventually settling with slender columnar dendrites $[39,40]$.

\subsubsection{Mechanical Properties of Powder Bed Fusion Additive Manufactured Ni Alloys Electron Beam Processed Ni Alloys}

Mechanical properties such as tensile strength, creep, and fatigue characteristic of $\mathrm{Ni}$ alloys built using EBM were vastly studied [108,110-112,138,150-153]. The pores, voids, and un-sintered powders are common types of defects that are observed frequently in EBMproduced parts [59]. These pores caused lower strength in the material. The application of HIPing with subsequent heat treatment and aging has shown to increase hardness and tensile strength as well as improve fatigue and creep rupture life of EBM-built IN718 due to reduction in defects $[117,118,154]$. A study conducted by Balachandramurthi et al. [118] reported an increase in ductility of EBM-built IN718 after subjecting to HIPing treatment. However, Goel et al. [117] did not report any significant change in ductility of the IN718 alloy after HIPing. Mechanical anisotropy was reported for EBM as-built and as-built followed by heat-treated IN718 in [112]. Higher yield strength and ultimate tensile strength 
but lower ductility and Young's modulus was found for sample loaded parallel to the building direction, as compared with that loaded perpendicular to the building direction which are probably due to texture, columnar grains and directional alignment of pores [112].
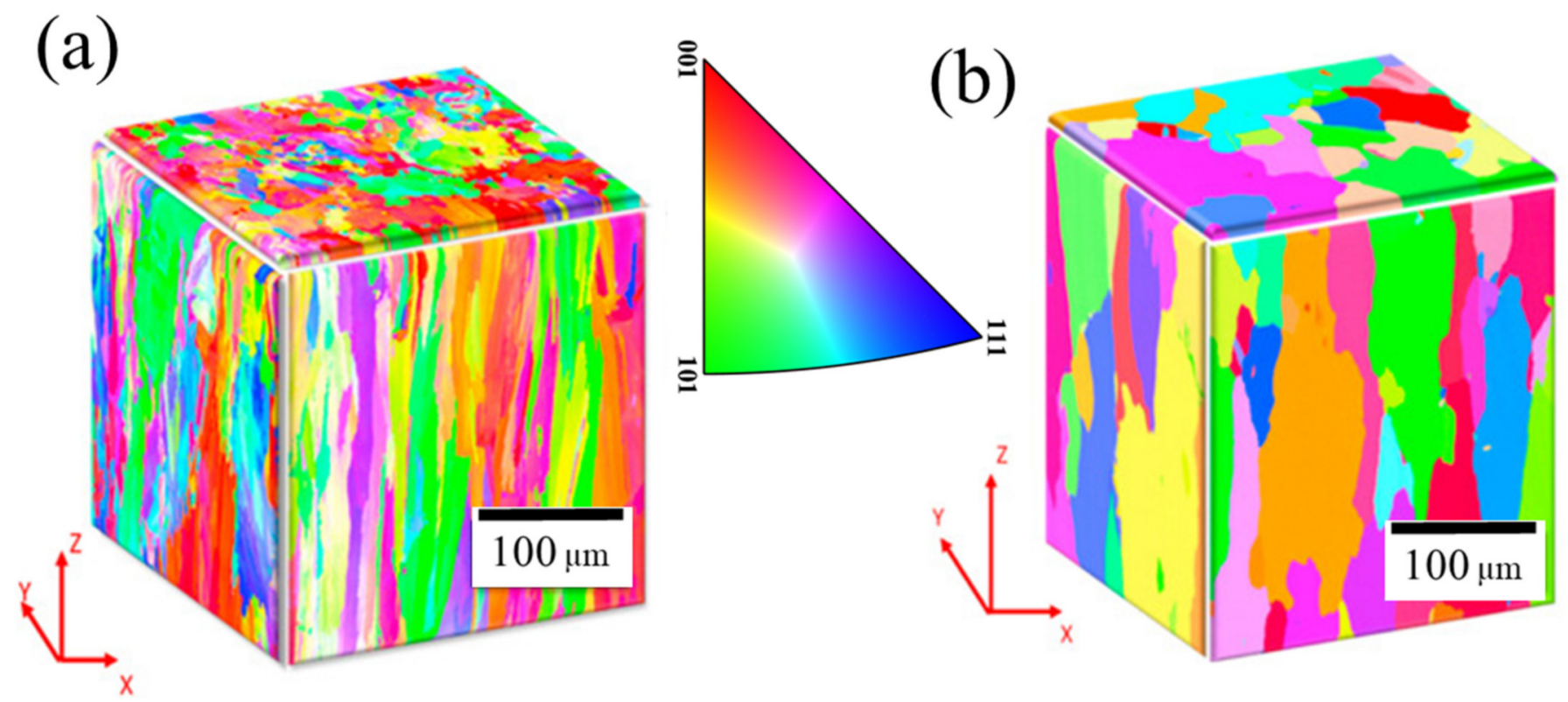

Figure 6. Electron backscatter diffraction of IN713LC fabricated using laser melting in (a) as built and (b) heat-treated at a temperature of $1175^{\circ} \mathrm{C}$ for $2 \mathrm{~h}$ conditions. Reprinted with permission from ref. [147]. Copyright 2021 Elsevier.

Laser-Processed Ni Alloys

In a study carried out by Mohsin Raza et al. [147], laser-processed IN713LC at appropriate processing conditions showed an average yield strength of $800 \mathrm{MPa}$, an ultimate tensile strength of $998 \mathrm{MPa}$, and ultimate elongation of $12.5 \%$ at room temperature, superior than those of as-cast IN713LC alloys with identical geometry and size. Solid solution heat treatment process of the alloy slightly improved yield strength, while the ultimate tensile strength and elongation decreased after heat treatment due to increase in grain size. They reported two micro-cracking mechanisms for this alloy, namely solidification cracking due to the segregation of elements at the grain boundaries and ductility dip cracking due to grain boundary sliding. The relative density of IN713LC components increased as much as $99.95 \%$ and crack density decreased below $0.011 \%$ when a lower laser energy density was used [147]. Several researchers investigated the mechanical properties of SLM-produced IN718 [39,121,122,125,129,138,155-177]. As energy density is increased, the micro-hardness of IN718 increased while the coefficient of friction decreased due to change in microstructure from coarsened columnar dendrites, to severely clustered dendrites, and eventually fine columnar dendrites $[39,40]$. This decrease in coefficient of friction also led to a decrease in the wear rate on the surface of the parts. There are contradictory results on the tensile properties of laser-processed IN718 compared to their conventionally produced counterparts. While Trosch et al. [176] reported lower tensile property of laser melted Inconel 718 alloy than that of conventional forged or cast Inconel 718 alloy, Pei et al. [178] found similar yield and tensile strengths of laser built Inconel 718 alloy, but lower ductility than those of forged counterparts. The fatigue performance of PBF-AM manufactured $\mathrm{Ni}$ alloys was also studied in [161,179-183]. Komarasamy et al. [179] reported negligible effect of powder atomization condition on the high cycle fatigue (HCF) resistance of laser-processed Inconel 718 alloy, and the HCF resistance could be enhanced by reducing $\delta$ phases along grain boundaries. Another study conducted by Yadollahi et al. [180] showed a lower HCF life for laser-processed Inconel 718 alloy compared to that of its wrought counterpart as a result of the defects such as un-melted powder and void formed during the AM process. Wan et al. [181] studied the effect of heat treatment on HCF behavior of Inconel 718 fabricated using laser powder bed fusion and found improvements in HCF 
resistance of the alloy after heat treatment compared to the as-built specimen, possibly because of the removal of Laves phases and the precipitation of $\gamma^{\prime}$ and $\gamma^{\prime \prime}$ phases in the microstructure. The effect of Laves phase on fatigue properties of IN718 was also studied by Sui et al. [182]. They found that the HCF resistance of AM Inconel 718 alloy at low stress range was superior than its conventionally fabricated counterpart because of the ability of Laves phases to hinder the propagation of fatigue crack, whereas at higher stress range, the Laves phases were broken by growing crack.

\subsubsection{Corrosion Behavior of Powder Bed Fusion Additive Manufactured Ni Alloys}

$\mathrm{Ni}$ alloys have been widely used in demanding environments where superior corrosion resistance is necessary, such as marine environments including the manufacture of heat exchangers, in the oil and gas industry and in nuclear plants $[184,185]$. Therefore, it is critical to study their corrosion behavior. The corrosion behavior of SLM Inconel 718 as a function of build orientations in a highly corrosive environment containing $13 \mathrm{wt} . \% \mathrm{NaCl}$ solution at $80{ }^{\circ} \mathrm{C}$ was reported by Klapper [184]. The SLM-fabricated Inconel 718 exhibited inferior pitting resistance to the conventionally produced counterpart. Furthermore, the effect of the build direction was negligible on the overall corrosion characteristics of the SLM Inconel 718 [184]. Hack et al. [186] studied the corrosion fatigue properties of alloy 625 fabricated using laser melting AM. It was found that the corrosion fatigue limit for laser PBF-processed alloy 625 part was independent of build orientation and slightly lower than the values for wrought material. In another study, Cabrini et al. [185] investigated the corrosion behavior of laser-built nickel-base alloy 625 (UNS N06625) with that obtained via conventional casting and hot working in $0.6 \mathrm{M} \mathrm{NaCl}$ solution at a $\mathrm{pH}$ of 7 and 3 , at $40^{\circ} \mathrm{C}$. The effect of heat treatment and surface polishing were also studied. They reported that the better pitting and localized corrosion resistance of the alloy produced by laser powder bed fusion in the considered environments than that of traditional wrought material may be attributed to its very fine microstructure and small and homogeneous distribution of second phases. Heat treatment did not change corrosion resistance of laser-processed samples, while mechanical polishing of the surfaces increased their corrosion resistance [185].

\subsection{Steel}

Steel has been attracted as a potential material widely used in various applications such as the defense, automotive, medical devices, and nuclear industries, owing to its outstanding mechanical properties and low cost [187]. However, the manufacturing of parts into complex shapes using conventional techniques is challenging. To date, a large number of different kinds of steels have been fabricated using powder based additive manufacturing technique including austenitic, duplex, martensitic and precipitation-hardening stainless steels, maraging and carbon-bearing tool steels and Oxide dispersion-strengthened (ODS) steels [26,188-199]. Due to high solidification rate in AM process, the alloys exhibited different microstructure and properties compared to their conventionally built counterparts which will be summarized in this section.

\subsubsection{Microstructural Characterization of Powder Bed Fusion Additive Manufactured Steel \\ Electron Beam Processed Steel}

Fully dense 316L stainless steel (SS) was successfully fabricated using electron beam melting additive manufacturing [193]. This alloy showed hierarchical microstructures consisting of solidified melt pools, columnar grains, and irregular shaped sub-grains. Lots of precipitates enriched in $\mathrm{Cr}$ and Mo were formed at columnar grain boundaries, whereas there was no elemental segregation at the sub-grain boundaries [193]. Hierarchical microstructure was reported in other studies [200,201]. Higher layer thickness led to formation of more defects in the sample [201]. H13 steel was also successfully prepared using electron beam melting [26]. The microstructure of EBM-built H13 was martensite and parts exhibited full interlayer bonding without any porosity. 


\section{Laser-Processed Steel}

Laser processing of steel alloy/composites was investigated by many researchers [189-191,195-199,202-208]. The 316L SS fabricated by laser bed fusion additive manufacturing showed fine equiaxed grains in plane perpendicular to the building direction, whereas grains were columnar along the building direction as expected for AM process [203]. The microstructure of conventionally fabricated 316L SS showed a larger grain size than its laser PBF-AM built counterpart [203]. The smaller grain size of AM built alloy was mentioned as a result of faster solidification rate. The size of columnar grain increased with increase in laser power [204]. Post-heat treatment of as-built 316L SS resulted in diminishing columnar structure and the microstructure is comparable to the wrought microstructure $[205,206]$. High magnification transmission electron microscopy (TEM) characterization of the SLM-built 316L SS showed a very fine cellular microstructure with cell sizes below $1 \mu \mathrm{m}$ as shown in Figure 7a,b [209]. Figure 7c shows the energy dispersive spectroscopy (EDS) map of the SLMprocessed 316L SS, indicating elemental segregation of $\mathrm{Cr}$ and Mo at cell walls [209]. Spherical shaped oxide inclusion enriched in $\mathrm{O}, \mathrm{Mn}$ and $\mathrm{Si}$ have been commonly reported in AM austenitic stainless steels (Figure 7c). However, it has been reported that the oxide inclusions in conventional austenitic stainless steels were larger $(>1 \mu \mathrm{m})$ and irregular-shaped $[210,211]$.

The homogenous cellular dendrite structure, which grew epitaxially along the build direction was also observed for AISI 420 martensitic steel [202]. The as-built microstructure was mainly martensitic; however, various amounts of austenite were formed with different morphologies depending on the heat input level. More austenite in the shape of separated longitudinal islands were retained at moderate heat input. Heat treatment of as-built ALSI 420 alloy removed the original dendrite structure leading to the formation of recrystallized grains composed of fine martensite with precipitation of carbides $\left(\mathrm{M}_{23} \mathrm{C}_{6}\right)$. The size of carbides was finer at lower and moderate heat input than at higher heat input. In Saeidi's work, the duplex stainless steel fabricated using a bidirectional scanning pattern with a constant 45 angle rotation between subsequent layers showed a Mosaic-type structure as shown in Figure 8a. The grain orientation map shown in Figure $8 \mathrm{~b}$ reveals that the grains inside each tessera have different orientation than the grains inside the adjacent tiles [212].

Through additive manufacturing, it is possible to add reinforcing secondary phases to the metals and alloys to improve their performance. The effect of nanoscale reinforcement on the microstructure of the SLM-built $\mathrm{TiB}_{2}$ and $\mathrm{TiC}$ reinforced 316L stainless steel was studied by AlMangour et al. $[207,208]$. Fine microstructure was observed after adding the reinforcement particles to the matrix as particles act as heterogenous nucleation sites. The effect of laser scanning strategies on porosity formation in SLM processed TiC reinforced 316L SS nanocomposites was explored [213]. It was reported that cross-hatched scanning strategy led to the highest densification.

\subsubsection{Mechanical Properties of Powder Bed Fusion Additive Manufactured Steel Electron Beam Processed Steel}

There are a few studies on the evaluation of mechanical properties of steel fabricated using EBM. The 316L SS alloy fabricated using electron beam melting at layer thickness of $100 \mu \mathrm{m}$ showed comparable hardness than its conventional counterpart prepared using hot iso-static pressing method. However, increasing the layer thickness resulted in decreasing the microhardness [201]. In another similar study, Olsén et al. [200] reported the lower microhardness of EBM-built 3161 SS than that of its counterpart prepared using SLM may be attributed to greater segregation of molybdenum, as well as the formation of numerous small precipitates during SLM. The as-built oxide dispersion strengthened ferritic steel fabricated using EBM showed higher ultimate tensile strength (UTS) than its annealed counterpart. UTS also increased with changes in scan strategy of test specimens from parallel scan lines to across scan lines between every layer due to the uniform nucleation as well as the higher relative density [214]. The effect of heat treatment on mechanical properties of EBM-built steel was studied in [26]. In this study, H13 steel fabricated using EBM showed hardness of 48-50 HRC, which decreased to 20 HRC after annealing [26]. 

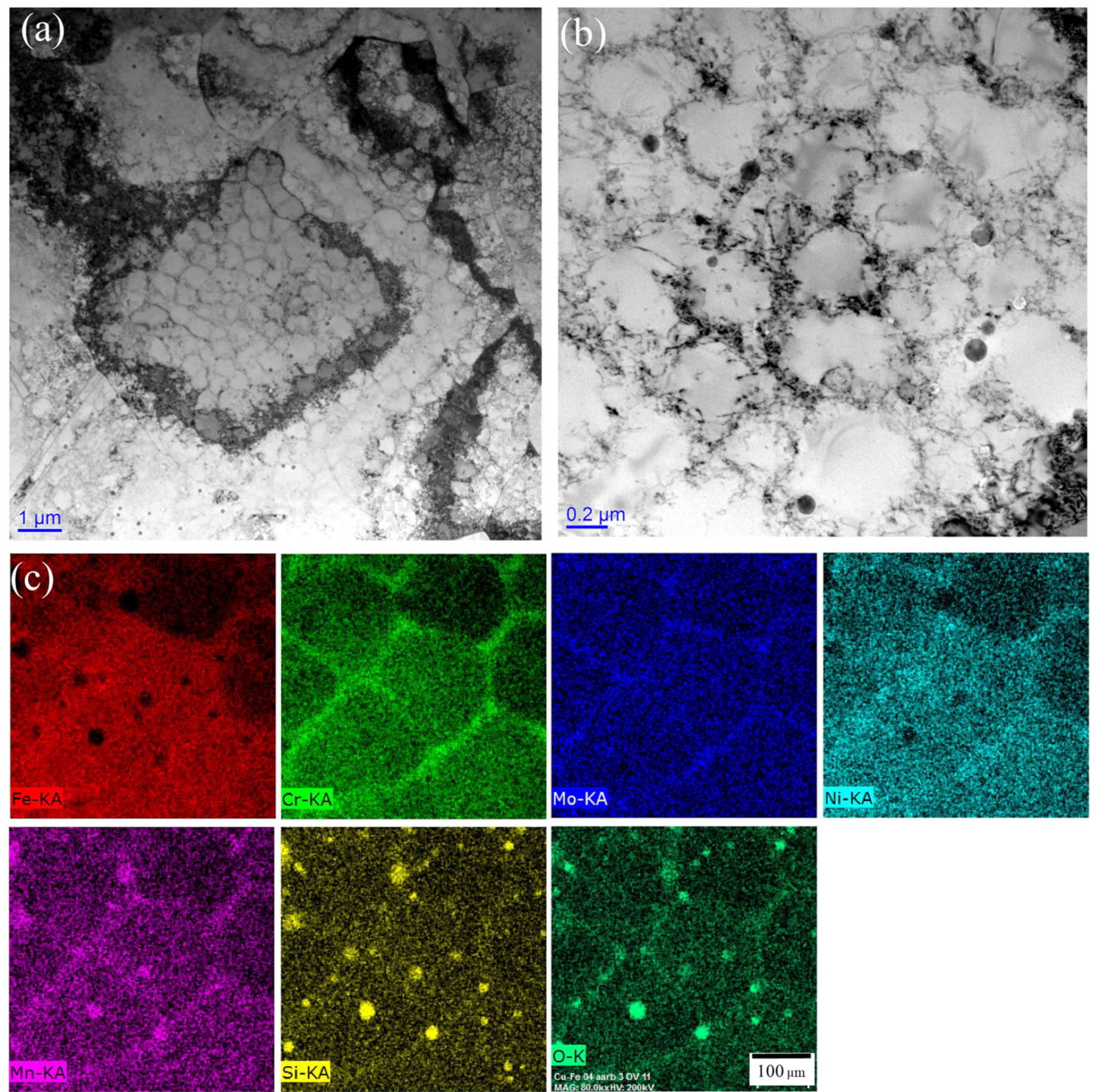

Figure 7. Transmission electron microscopy (TEM) images (a) low magnification, (b) higher magnification, and (c) the energy dispersive spectroscopy TEM of SLM-built 316L SS. Adapted from ref. [209]. 

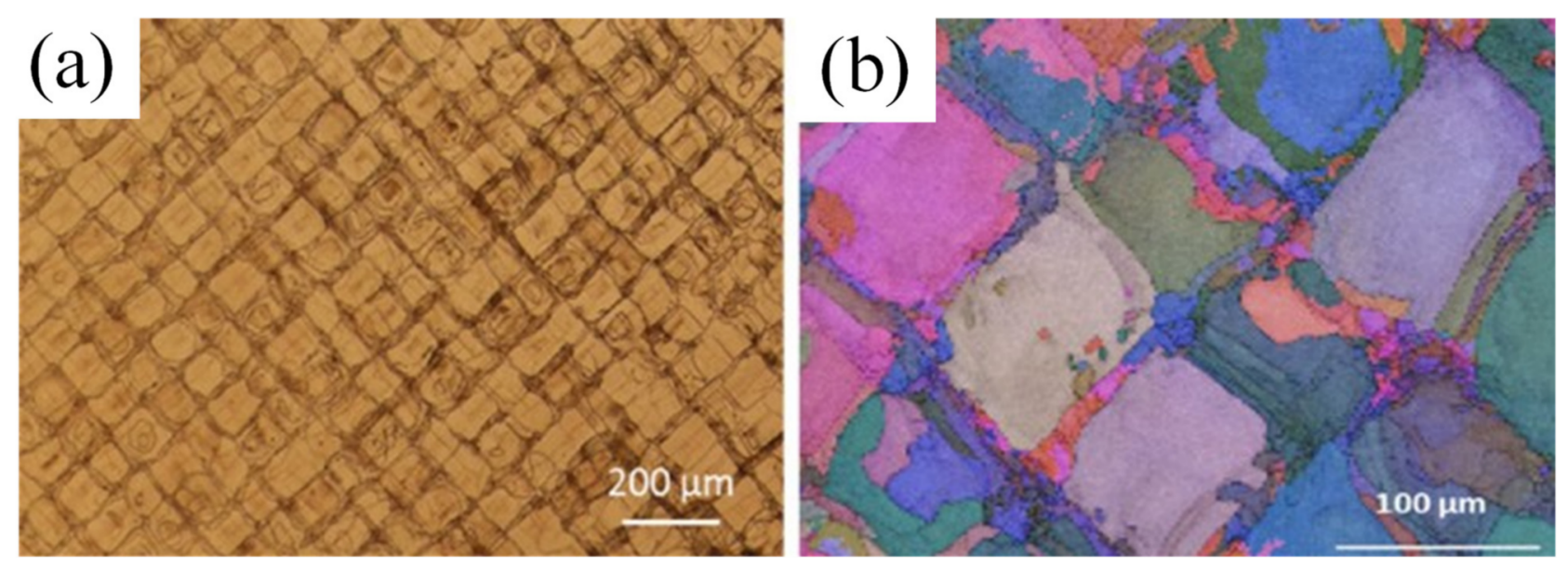

Figure 8. (a) Optical microscopy images and (b) grain orientation map of the laser-processed SAF2507 duplex steel. Reprinted with permission from ref. [212]. Copyright 2021 Elsevier.

\section{Laser-Processed Steel}

The 316L stainless steel fabricated using laser processing showed $\sim 34 \%$ higher ultimate tensile strength and ductility, and twice the yield strength than its wrought/cast counterpart, which may be due to the formation of nano-inclusions in AM-built steel that hinder dislocation movements, and a large density of low angle grain boundaries [215,216]. In other similar studies, the AM-built steel alloys exhibited superior strength, but lower ductility than the cast or wrought material [217-230]. It has been reported that due to refine microstructure, the strength of AM samples increased, whereas the ductility decreased as a result of defects such as porosity. Davidson et al. [231] reported higher hardness of laser PBF 2507 duplex stainless steel than wrought alloy. In their study, decreasing laser energy density resulted in improvement in hardness, mainly due to a corresponding decrease in the austenite content. In a similar study carried out by Saeidi et al. [212], a bidirectional scanning pattern with a constant 45 angle rotation between subsequent layers resulted in improvements in the strength of the laser powder bed-processed 2507 DSS. This was attributed to the mosaic type microstructure in this alloy after processing, the high concentration of dislocations inside the material, nano-oxide inclusions and chromium nitride precipitates, and solid solution strengthening due to the solubility of nitrogen $(\mathrm{N})$ in the ferrite structure steel [212]. AISI 4140 fabricated using laser processing AM also showed equivalent or superior mechanical properties to conventionally processed (and heat-treated) steel due to the formation of small solidification grains and ultrafine cell structures. Due to unidirectional heat transfer along the build direction in the AM of AISI 4140, anisotropic mechanical behavior was observed. XY direction (parallel to build direction) showed a higher yield strength, ultimate tensile strength, and elongation than the $\mathrm{Z}$ direction (along the build direction), due to elongated grains along the build direction [202]. It was stated that the twinning-induced plasticity (TWIP) effect can be activated in laser melting of 316L austenitic stainless steel [232] which led to its high ductility despite defects. The N presence in AM may decrease stacking fault energy of 316L steel and trigger twinning formation. The better creep, fatigue fracture toughness, and wear resistance of stainless steel alloys compared to their conventionally produced counterparts was reported in [217,233-239]. In some studies, it was found that a AM-built steel alloys showed a lower fatigue resistance than wrought samples, due to surface roughness and defects; these alloys showed inferior fatigue behavior even after post-heat treatment [240-244].

The effect of post-heat treatment on properties of different kinds of steel alloys was investigated in some studies $[245,246]$. Sridharan et al. $[245,247]$ showed that a post-heat treatment decreased the strength, probably due to change in grain size and precipitate distributions, but improved the ductility of HT9 and P91 steel, at room and elevated temperatures. 


\subsubsection{Corrosion Behavior of Powder Bed Fusion Additive Manufactured Steel}

The 316L stainless steel fabricated using SLM showed better corrosion resistance than its conventionally fabricated alloy because of high solidification rate of process which avoids the formation of $\mathrm{MnS}$ and associated $\mathrm{Cr}$-depletion zones. Cr-depletion zones are known as pit initiation sites [248-253]. Moreover, the superior hydrogen damage resistance of laser PBF 316L austenitic stainless steel compared to its conventional counterpart has been reported by Kong et al. [254] and Baek et al. [255] due to the lower volume fraction of martensite in laser-processed 316L austenitic stainless steel, and the stability of the austenite phase that does not transform to martensite phase under load stress, indicating their potential application in hydrogen fuel cells [254,255]. Schaller et al. [256] studied the corrosion behavior of laser PBF 17-4 PH steel, showing a reduced corrosion resistance of additively manufactured steel compared to its conventionally produced counterpart may be because of the porosity in the laser melted samples acting as active corrosion sites. The opposite result was reported by Stoudt et al. [257], showing that the better corrosion resistance of $17-4$ PH samples produced by laser PBF than wrought samples may be attributed to more homogeneous distribution of elements in the microstructure, making it more resistant to localized corrosion, as well as due to the absorbance of $\mathrm{N}$, while AM resulted in a more stable passive film. PBF-AM-built steel parts with higher porosity and thus lower density exhibited lower corrosion resistance than wrought parts $[249,258]$. Irrinki et al. [258] reported that increasing the energy density from $64 \mathrm{~J} / \mathrm{mm}^{3}$ to $104 \mathrm{~J} / \mathrm{mm}^{3}$ led to an increase in the density of laser-processed PH SS alloy, and accordingly a better corrosion performance. The effect of scanning speed on corrosion behavior of SLM-built 316L SS was studied by Ni et al. [252]. An increase in scanning speed resulted in the formation of more voids acting as pitting sites, consequently decreasing the corrosion resistance of the alloy.

\subsection{Aluminum (Al) Alloys}

High thermal conductivity materials such as aluminum and copper are of particular interest because of the large number of applications, such as structural aerospace components [259] or electrical components [260]. In this section, the microstructure and properties of high conductive alloys fabricated using the PBF-AM technique are summarized.

4.4.1. Microstructural Characterization and Part Quality of Powder Bed Fusion Additive Manufactured Al Alloys

Electron Beam Processed Al Alloys

A feasibility study on the processing of various aluminum alloys, namely 2024, 7075, and 6061, using the Arcam S12 EBM system was reported [261-263]. The purpose of these experiments was to use a wide range of process settings, both preheat and melt parameters (beam speed and power), to narrow down a processing window for the production of fully dense parts. However, the 2024 alloy exhibited significant porosity and cracking. Some 2024 tensile samples cracked during removal from the start plate and some cracked during machining into tensile bars, indicating that stress cracks were preexisting in the parts or brittle material, which is typically not expected for aluminum. However, the majority of parts that were heat-treated under T6 solution heat-treated conditions showed significant improvements in UTS. Some loss of strength was attributed to loss of large amounts of alloying elements due to overheating of the melt pool. These elements lead to strengthening of the alloy through heat treatment by precipitating at the grain boundaries and inhibiting the movement of dislocations. In the absence of these elements, the heat treatment will have no effect on the UTS [261,262]. Kenevisi et al. [263] found optimum input energy to obtain A12024 alloy with high relative density using EBM technique. The microstructure of EBM-built alloy was crack-free and exhibited equiaxed grains with high angle grain boundaries having different crystallographic orientations and a few sub-grains. Furthermore, homogeneously distribution of $\mathrm{AlCuMnFe}, \mathrm{AlCuMnFeSi}$, and eutectic $\mathrm{Al}_{2} \mathrm{Cu}$ phases were found in the $\alpha$-phase matrix. 
To retain the final chemistry and reducing porosity, several approaches were proposed, including mechanical alloying of the starting powder with the aluminum alloy that is mixed with additional alloying elements and increases the weight percent of the alloying elements in the pre-alloyed starting powder. It was found that unless the two powders were of similar density, they would separate upon melting and create bands of the two materials instead of becoming homogeneous. The second method was also unsuccessful because faster vaporization of those elements resulted in the same amount of loss and also increased the porosity [262]. However, the same study reported dense structures and low porosity in alloy 6061 made using EBM. SEM analysis showed a formation of iron aluminide precipitates within the first $15-20 \mathrm{~mm}$ of the samples. This was deemed to be from a reaction with the iron in the steel start plate.

\section{Laser-Processed Al Alloys}

The high optical reflectivity of metals such as copper or aluminum makes their processing using SLM very challenging [264,265]. Since much of the energy is reflected or conducted away from the melt pool region, processing of these materials requires a very high beam energy to achieve a proper melt. The feasibility of fabricating $\mathrm{Al}$ alloys using laser powder bed fusion AM has been studied by many researchers [265-284]. Most of the research in the literature has been focused on optimizing the process to achieve quality parts.

In order to obtain fully dense parts from $\mathrm{AlSi}_{10} \mathrm{Mg}$, Buchbinder et al. [285] showed that it is necessary to have a high laser power (over $150 \mathrm{~W}$ ) which significantly reduced balling and porosity. The high reflectivity of aluminum causes the majority of the laser energy to not be absorbed into the powder bed and the higher laser power overcomes those losses. Aluminum oxidation is a problem in conventional manufacturing, and this effect is amplified in AM because of the greater surface area of oxide on each granule of powder that is disrupted and incorporated into the melt pool. $\mathrm{Al}_{2} \mathrm{O}_{3}$ oxide is very stable and does not react further within the molten aluminum. Once the oxide enters into the melt pool, it contaminates the solidified metal and can create pores and areas of weakness.

Wong et al. [286] were able to manufacture various heat transfer devices out of 6061 aluminum. They were able to show that much more complex heat sink designs were possible such as diamond-shaped cross section pins and also a V-shaped array using staggered ellipses. These designs are not able to be manufactured through conventional methods and have better performance over previous designs. Abe et al. [192] investigated the manufacturing of hard tools from various metals using SLM. The aluminum experienced balling which was attributed to the formation of an oxide layer on the surface of the liquid metal that increased the surface tension. Bartkowiak et al. [276] attempted to create their own custom high-strength aluminum alloy powder systems by blending together powders of aluminum $\left(\mathrm{d}_{50}=35 \mu \mathrm{m}\right)$ and copper $\left(\mathrm{d}_{50}=3 \mu \mathrm{m}\right)$, and also blending aluminum $\left(\mathrm{d}_{50}=35 \mu \mathrm{m}\right)$ and zinc $\left(\mathrm{d}_{50}=5 \mu \mathrm{m}\right)$ at various percentage concentrations. These custom powder blends were then processed via SLM and compared to their standard pre-alloyed counterparts of 2xxx series Al-Cu and 7xxx series Al-Zn alloys, respectively. Each sample exhibited a very fine microstructure, no cracking, and no evidence of an external oxide layer.

Other aluminum alloys were examined by Olakanmi [287]. However, rather than on the process itself, this study focused on the effect of powder properties on the resulting part quality. Various aluminum alloys were used to develop a suitable processing window to increase the relative density and reduce the balling phenomenon. The powders used were air-atomized pure aluminum, inert gas-atomized pure aluminum, water-atomized prealloyed $\mathrm{Al}-5.7 \mathrm{Mg}$, water atomized pre-alloyed $\mathrm{Al}-6 \mathrm{Mg}$, and inert gas atomized pre-alloyed Al-12Si. It was found that the different alloys had similar processing windows, which was contributed to very similar tapped densities and therefore similar thermal conductivity throughout the powder bed. The varying oxide content in the precursor powders did not have any major effect on the overall processing window boundaries. The powders 
which were more irregularly shaped showed better consolidation at lower scan speeds, which was attributed to the greater surface area and better energy absorption. However, the irregular particles increased the resulting porosity. The general trend with all material samples show that it requires a relatively high laser power of 100-240 $\mathrm{W}$ and a moderate scan speed between 80 and $200 \mathrm{~mm} / \mathrm{s}$ to obtain solid (yet still porous) structures without balling. Decreasing the scan speed and increasing the energy density beyond that results in a large melt pool and balling. The balling phenomena and porosity seen with the various aluminum powders testing was due to a few factors. First, the higher oxide content changes the Marangoni coefficient and causes the melt pool shape to become deeper and narrower. This creates large pores in between the scan tracks as the melt pool narrows. Next, the chemistry of the alloy alters the surface tension and wettability of the liquid phase. The presence of silicon increases the wettability of the melt with the powder bed, whereas the increased content of magnesium reduces the wetting and leads to balling. Finally, more balling is seen during the first few layers due to the cold powder bed causing the melt pool to form agglomerates. The lower temperature gradient within the melt pool reduces the surface tension and has a more controlled Marangoni flow.

Al-8.5Fe-1.3V-1.7Si, also known as FVS0812, is a castable high strength aluminum alloy. Zheng et al. [288] investigated the feasibility of producing this alloy via SLM and compared the mechanical and material properties to the as-cast properties. They employed a scanning technique that scanned each layer twice, with the secondary scan pattern traversing at 90 degrees to the initial scan. Microstructural analysis revealed the presence of the stable $\alpha-\mathrm{Al}$ and $\mathrm{Al}_{12}(\mathrm{Fe}, \mathrm{V})_{3} \mathrm{Si}$ phases, which gives the material its exceptional mechanical properties. There was the formation of $\theta-\mathrm{Al}_{13} \mathrm{Fe}_{4}$ at the boundary between the heat-affected zone and the melt pool region. Thapliyal et al. [275] and Mishra et al. [289] were able to prepare crack-free laser-processed $\mathrm{Al}$ alloys in a wide processing window using combination of grain refinement through heterogeneous nucleation and eutectic solidification strategies. The microstructure evaluation of Al-3Ni-1Ti-0.8Zr (wt.\%) alloy showed fine equiaxed grains nucleated on $\mathrm{Al}_{3}(\mathrm{Ti}, \mathrm{Zr})$ precipitates, and coarse columnar grains with higher cracking resistance as a result of a terminal $\mathrm{Al}-\mathrm{Al}_{3} \mathrm{Ni}$ eutectic [275]. Another study worked to prepare crack-free 7xxx Al alloys through co-incorporation of submicron $\mathrm{Si}$ and TiB2 into the alloys [290]. Gharbi et al. [291] reported the microstructure of as-SLMed AA7075 containing the quasi-crystalline phase ( $v$-phase) as the principal nano-structural feature. Solution heat treatment dissolved the quasi-crystalline $v$-phase and ageing led to precipitation of $\eta^{\prime}$-phase $\left(\mathrm{MgZn}_{2}\right)$ within grains and along grain boundaries, revealing columnar grains in the microstructure of AA7075 alloy.

\subsubsection{Mechanical Properties of Powder Bed Fusion Additive Manufactured Al Alloys Electron Beam Processed Al Alloys}

There are limited reports on mechanical properties of $\mathrm{Al}$ alloys built using EBM [263]. A microhardness study of the A2024 alloy fabricated using EBM showed a nearly uniform change in hardness values in the range of $100 \mathrm{HV}$ to $110 \mathrm{HV}$ in both horizontal and vertical sections, which was higher than the annealed Al2024 wrought alloy, but lower than that of its counterpart in T6 solution-treated condition. The as-built alloy exhibited tensile and yield strengths of $314 \mathrm{MPa}$ and $191 \mathrm{MPa}$, respectively, which can be improved by an appropriate post-processing treatment [263].

\section{Laser-Processed Al Alloys}

The mechanical properties of SLM as-built and heat-treated $\mathrm{Al}$ alloys at room and elevated temperatures has been reported in [192,263,265,266,279,281,283,288,292-313]. Laserprocessed $\mathrm{Al}$ alloys showed twice higher yield strength than as-cast $\mathrm{Al}$ alloys and comparable strength to age-hardened wrought $\mathrm{Al}$ alloys [289]. In a study carried out by Lam et al. [312], AlSi10Mg parts produced using SLM showed higher hardness and tensile strength than traditionally fabricated counterparts. They concluded these improvements are due to three factors: (i) the fine microstructure favoring grain boundary strength- 
ening, (ii) the alloying elements resulting in solid solution strengthening, and (iii) the strengthening as a result of dislocations interactions. In the study by Louvis et al. [265], 6061 samples were tensile tested and the fracture surfaces were examined. They showed flat facets that indicate failure due to the presence of thin oxide films instead of failure through plastic deformation. Additionally, shown in the fracture areas were regions of un-melted powder, from not being incorporated into the melt pool. This implies that the presence of the oxide film inhibited the melt pool from wetting with regions of precursor powder. Abe et al. [192] found that using an additional $\mathrm{CO}_{2}$ laser offset from YAG laser to reheat the solidified region below melting temperature and reduce the cooling rate led to an improvement in strength and ductility and reduction in hardness of SLM-built Al samples. The microhardness of two FVS0812 samples fabricated using a laser power of $150 \mathrm{~W}$ and a scan speed of 250 and $200 \mathrm{~mm} / \mathrm{s}$ yielded hardness values of 135-170 HV and 145-175 HV, respectively. As a comparison, the conventional as-cast material only has a hardness of 40-45 HV. Buchbinder et al. [314] investigated the effect of laser power and scanning speed on mechanical properties of SLM-fabricated AlSi10Mg alloy. They found that laser power has negligible effect on the yield strength and ultimate tensile strength of $\mathrm{Al}$ alloys. However, a sample prepared at higher laser power showed a higher elongation than that fabricated at lower laser power [314].

Bai et al. [315] studied the mechanical properties of an as-built SLMed AlSiMg 0.75 alloy in comparison to its annealed and cast counterparts, indicating the higher yield strength and tensile strength, but lower elongation, of the as-built alloy. This result was contradictory to the results reported by Bi et al. [279] for the Al-14.1Mg-0.47Si-0.31Sc$0.17 \mathrm{Zr}$ alloy. The tensile properties of this alloy increased after heat treatment due to combination of fine grain strengthening, solid solution strengthening and precipitate strengthening. The grain size of this alloy did not change after heat treatment and the tensile properties increased due to combination of fine grain strengthening, solid solution strengthening and precipitate strengthening. The fracture morphology of AlMgSiSc Zr alloy showed a mixed toughness and brittleness failure. In addition, SLM-produced Al alloy showed superior fatigue resistance in comparison to the standard DIN EN 1706 [292]. Brandl et al. [292] investigated the high cycle fatigue (HCF) and fracture behavior of SLM additive manufactured AlSi10Mg samples as a function of building platform temperature and building directions. Samples were studied in as-built condition and the T6 solution heat-treated. Results showed that building direction and build plate temperature does not have a significant effect on fatigue properties; however, the effect of the post-heat treatment was significant. The same results were reported in another study [316].

\subsubsection{Corrosion Behavior of Powder Bed Fusion Additive Manufactured Al Alloys}

There are limited studies on the corrosion behavior of powder bed fusion additive manufactured Al alloys [279,291,317]. Bi et al. [279] evaluated the corrosion performance of the SLM-fabricated Al-14.1Mg-0.47Si-0.31Sc-0.17 Zr alloy in comparison to its heat-treated counterpart in $3.5 \mathrm{wt}$ \% $\mathrm{NaCl}$ solution. The as-built $\mathrm{Al}$ alloy exhibited an excellent corrosion resistance due to its fine grain size of $2.53 \mu \mathrm{m}$. The heat-treated sample showed inferior corrosion resistance, which was attributed to the formation of porous oxide layer and pitting corrosion induced by diffuse precipitation distribution. Gu et al. [317] investigated the corrosion behavior of Sc- and Zr-modified Al-Mg alloy processed by SLM on different planes in $3.5 \mathrm{wt} . \% \mathrm{NaCl}$ solution at room temperature. Results showed the lower corrosion current density $\left(i_{\text {corr }}=57.1 \mu \mathrm{A} \mathrm{cm}^{-2}\right)$ of the XY plane than of the XZ plane $\left(i_{\text {corr }}=200 \mu \mathrm{A} \mathrm{cm}^{-2}\right)$. However, the $X Z$ plane displayed a better pitting resistance; fewer but deeper pits were formed on the $X Z$ plane, whereas wide and shallow pits were formed on the $X Y$ plane after polarization test. The anisotropic corrosion resistance of the SLM-produced Al-Mg-Sc-Zr alloy may be associated with the different microstructures of the alloy on different planes, including melt pool boundary, distribution of $\mathrm{Al}_{3}(\mathrm{Sc}, \mathrm{Zr})$ precipitation, grain size distribution, and crystallographic orientation as shown in Figure 9 schematically [317]. Figure 9a,b displayed higher melt pool boundaries and bimodal grain structure for the $\mathrm{XZ}$ plane than 
the $X Y$ plane with lower melt pool boundaries and equiaxed cellular structure. This led to a higher density of $\mathrm{Al}_{3}(\mathrm{Sc}, \mathrm{Zr})$ precipitations on the $\mathrm{XZ}$ plane than that on the $\mathrm{XY}$ plane (Figure 9d), which facilitate the breakdown of the $\mathrm{Al}(\mathrm{OH})_{3} / \mathrm{Al}_{2} \mathrm{O}_{3}$ surface passive film and accelerate the failure of the surrounding matrix (Figure 9e). Figure 9c shows the different crystallographic orientation of two planes, which may result in anisotropy in corrosion behavior.

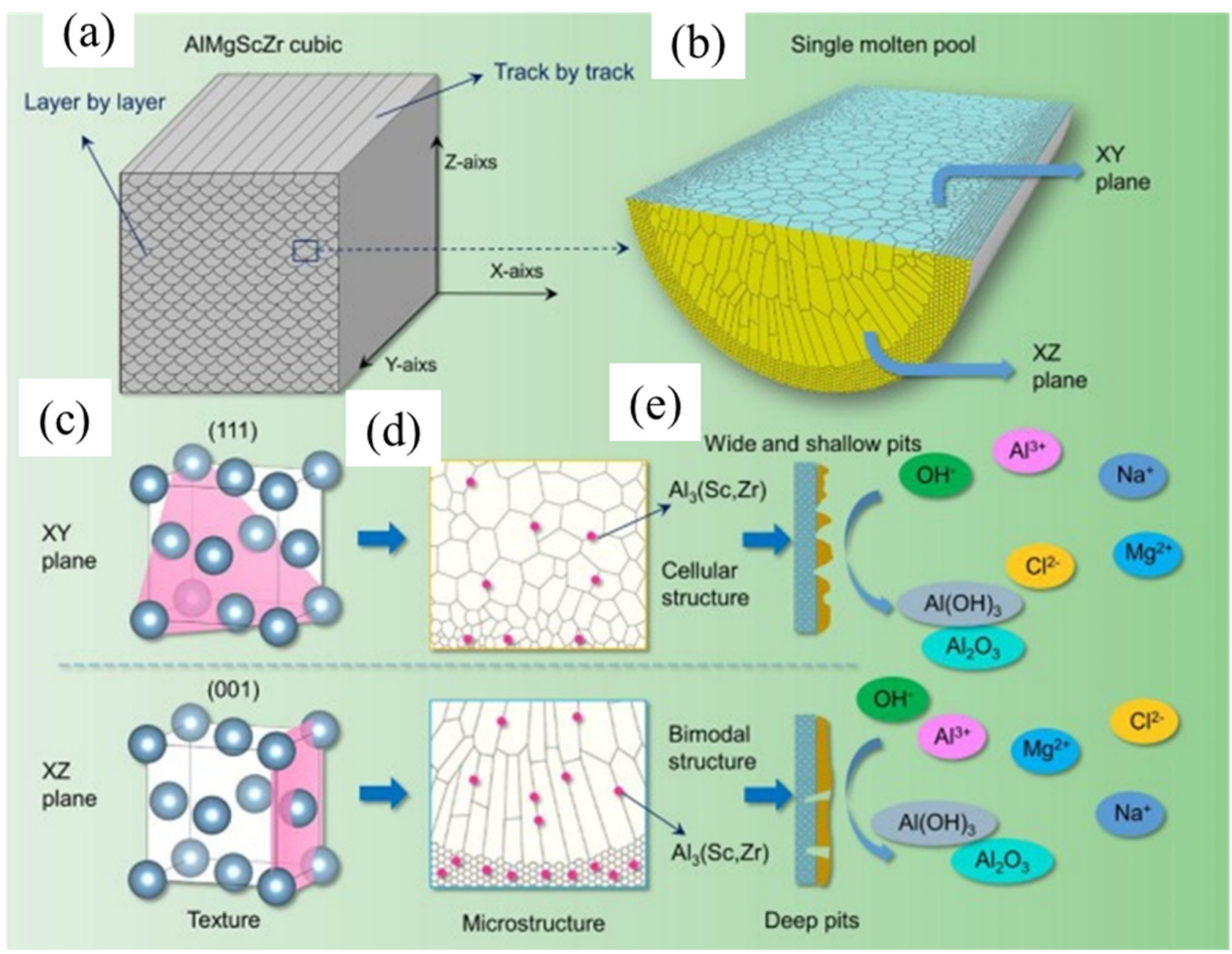

Figure 9. Schematic of different microstructures and corrosion mechanisms on $\mathrm{XY}$ and $\mathrm{XZ}$ planes of Al-Mg-Sc-Zr alloy fabricated using selective laser melting: (a) melt pool boundary densities on XY and XZ planes; (b) distribution of grain size in a single melt pool; (c) preferred crystallographic orientations on $\mathrm{XY}$ (top) and $\mathrm{XZ}$ (bottom) plane; (d) $\mathrm{Al}_{3}(\mathrm{Sc}, \mathrm{Zr})$ precipitation distributions on XY (top) and XZ (bottom) planes; (e) corrosion mechanisms on XY (top) and XZ (bottom) planes. Reprinted with permission from ref. [317]. Copyright 2021 Elsevier.

In another study, the corrosion behavior of SLM-fabricated AA7075 in $0.1 \mathrm{M} \mathrm{NaCl}$ was studied in three different conditions including as-built, as-built + solutionized + quenched, and as-built + solutionized + quenched + aged at $120{ }^{\circ} \mathrm{C}$ for $24 \mathrm{~h}$ and compared with those of wrought AA7075-T6. The as-built AA7075 alloy showed superior corrosion resistance to the wrought AA7075-T6. Pits formed in SLM produced AA7075 after corrosion tests were remarkably smaller in comparison to those upon wrought AA7075-T6 due to its finer microstructural features and the absence of large constituent particles. In the as-built AA7075 condition, pits were more pronounced along melt pool boundaries, while they were uniformly distributed in the solutionized sample, and the following ageing caused larger pits along grain boundaries than those within grains [291]. 


\subsection{Copper (Cu) Alloys}

4.5.1. Microstructure Characterization and Part Quality of Powder Bed Fusion Additive Manufactured Cu Alloys

Electron Beam Processed Cu Alloys

The EBM technology offers unique features that other additive manufacturing technologies or even traditional manufacturing methods cannot offer. One of these is the in-process heat treatment capability through the utilization of the elevated build temperature and precise melt pool temperature control. Murr et al. $[65,318]$ sought to exploit these features to produce a precipitation-hardened copper structure with cuprous oxide $\left(\mathrm{Cu}_{2} \mathrm{O}\right)$ precipitates. When processing $99.8 \%$ pure $\mathrm{Cu}$ powder via EBM, trace levels of oxygen present in the powder bed react to form $\mathrm{Cu}_{2} \mathrm{O}$ precipitates, with a bias parallel to the build direction. The $\mathrm{Cu}_{2} \mathrm{O}$ forms in irregular, cell-like shapes. It is suggested from these results that altering the EBM process parameters can change the spatial configuration of the precipitations, and thus affect the resulting material properties. Frigola et al. [319] examined the $\mathrm{Cu}_{2} \mathrm{O}$ oxide formation further by building samples with $99.99 \%$ high purity copper powder and also $99.8 \%$ low purity copper at different process parameters. The low purity copper powder exhibited the same microstructure and precipitation formation as Murr et al. [65,318], although it was noted that the part quality suffered with the increase in the amount of oxidation. The high purity copper powder formed large columnar grains with lower levels of $\mathrm{Cu}_{2} \mathrm{O}$ precipitates. With an increase in build temperature, the microstructure resembled that of conventional annealed copper; large equiaxed and non-directional grains. Ramirez et al. built reticulated mesh and randomized stochastic foam structures [320] and solid samples [28] via EBM using 99.8\% pure $\mathrm{Cu}$ powder. The resulting microstructure contained $\mathrm{Cu}_{2} \mathrm{O}$ precipitates that originated from the precursor powder and were also generated during melting from residual oxygen within the powder. The inclusion of $\mathrm{Cu}_{2} \mathrm{O}$ was found to precipitation-harden the resulting material, noted by an increase in the strength and hardness of the mesh struts and foam ligaments. As with mesh structures fabricated from other materials, the stiffness of the meshes varies with its density and porosity.

Since the majority of components made from copper are used for either electrical or thermal applications, the amount of impurities must be minimized for the best performance. Lodes MA et al. [321] explored the production of pure copper components using $99.94 \%$ pure copper precursor powder. A processing window was developed that resulted in fully dense parts, with large columnar grain growth oriented in the build direction, which is typical of EBM-produced metals. Fully dense $(99.5 \%)$ parts were obtained with a line energy of $0.3 \mathrm{~J} / \mathrm{mm}$ and a scanning speed of $3000 \mathrm{~mm} / \mathrm{s}$, and they did not have any significant precipitations. $\mathrm{Cu}-8 \mathrm{Cr}-4 \mathrm{Nb}$ was developed by NASA as an alloy that will retain its strength over a very large temperature range, such as in the liner of rocket engines. This material is expensive to produce into complex shapes and is not castable because the $\mathrm{Cr}_{2} \mathrm{Nb}$ precipitates will grow to an unacceptable size. Therefore, the production of $\mathrm{Cu}-8 \mathrm{Cr}-4 \mathrm{Nb}$ was investigated by Mahale [262] to determine whether the rapid solidification of EBM would be sufficient to maintain the small precipitate size. After being built via EBM, the samples had a measured precipitate size of $1 \mu \mathrm{m}$ or smaller and had minimal loss of alloying elements. The strength of the samples at elevated temperatures was similar to that of the samples made by conventional methods.

\section{Laser-Processed Cu Alloys}

The attempts to process pure copper with laser powder bed fusion additive manufacturing technologies have seen various levels of success [322,323]. Jadhav et al. [322] were able to use laser melting for pure copper and fabricated bulk solid copper parts with near full density $>99 \%$. They used a conventional infrared fiber laser with $1080 \mathrm{~nm}$ wavelength, a small focal spot diameter of $37.5 \mu \mathrm{m}$, power at $500 \mathrm{~W}$, and a volumetric energy density window of 230-310 J/ $\mathrm{mm}^{3}$. In another study, Silbernagel et al. [323] fabricated high density $(\sim 86 \%)$ pure copper at optimized processing parameter as $200 \mathrm{~W}$ laser power, 
spot diameter of $35 \mu \mathrm{m}$, a laser scan speed of $300 \mathrm{~mm} / \mathrm{s}$, and layer thickness of $45 \mu \mathrm{m}$. Tang et al. [324] used an experimental laser sintering machine with a $200 \mathrm{~W} \mathrm{CO}_{2}$ laser called high-temperature metal laser sintering (HTMLS) to investigate the processing of copper-based alloys. They employed a copper-based powder system consisting of copper as the structural material and a binder of copper phosphide $\left(\mathrm{Cu}_{3} \mathrm{P}\right)$, mixed at various ratios. During liquid phase sintering, the phosphorus dissolves any surface oxides and improves the wetting of the molten copper. They found that it was necessary to use a high laser power and slower scan speed in order to achieve higher density, although the dimensional accuracy of the final parts suffered. In a recent study, Demeneghi et al. [325] fabricated copper-4at.\% chromium-2at.\% niobium alloy using laser powder bed fusion method as a function of sample thickness ranging from $0.7 \mathrm{~mm}$ to $2 \mathrm{~mm}$. As the sample thickness increased, the porosity decreased, resulting in better mechanical properties. The microstructure characterization of as-built $\mathrm{Cu}-\mathrm{Cr}-\mathrm{Zr}$ alloy showed uniform grain arrangement on the horizontal $(X Y)$ plane which grew towards the center of the molten track at a certain angle to the laser scanning direction due to temperature gradient. The grains are elongated along the building direction on the vertical $(X Z)$ plane of the as-built sample. On both XY and XZ planes, epitaxial growth of grains was visible. Intermetallic compound particles $\left(\mathrm{Cu}_{x} \mathrm{Zr}_{y}\right)$ were found in both as-built and heat-treated SLMed CuCrZr alloy. Heat treatment resulted in the $\mathrm{Cr}$ particles precipitation in addition to the formation of intermetallic compound particles [326].

\subsubsection{Mechanical and Conductivity Properties of Powder Bed Fusion Additive Manufactured Cu Alloys}

The mechanical properties of $\mathrm{Cu}$ metals and alloys fabricated using powder bed fusion additive manufacturing have rarely been investigated in as-built and post-processed conditions [326,327]. The as-built pure copper parts using laser melting exhibited a tensile strength of $211 \pm 4 \mathrm{MPa}$, a yield strength of $122 \pm 1 \mathrm{MPa}$, an elongation at failure of $43 \pm 3 \%$, and an electrical conductivity of $94 \pm 1 \%$ IACS [322]. In another investigation, a $\mathrm{Cu}-\mathrm{Cr}-\mathrm{Zr}$ alloy built using SLM showed the microhardness of $118.2 \mathrm{HV}$, which decreased after solution treatment to $90.5 \mathrm{HV}$, but enhanced after solution + ageing treatment to 127.4 HV. Top and side surfaces of all samples showed relatively identical microhardness. The tensile and compressive yield strength also decreased in the same order as ageing $>$ as-built $>$ solution-treated. The fracture mechanisms of all samples after tensile tests were found to be ductile-fracture dimples. The dimples were smaller for the as-built and solution treated samples than for the age treated counterpart. The pore and inclusion defects without any large cracks were reported in the fracture's surfaces of all the samples and the microstructure was heavily deformed and refined with twin formation [326]. In a study carried out by Demeneghi et al. [325] and Robinson et al. [327], the mechanical properties of SLM-built $\mathrm{Cu}$ alloys was improved by decreasing porosity through increasing sample thickness and Ag addition, respectively.

Electrical resistivity of laser-processed pure copper was investigated and was found to be dependent on initial build orientation, with horizontal and 45-degree builds exhibiting the lowest resistivity, maybe due to variations in the different interlayer and intralayer defects caused mainly by the lack of fusion and un-melted powder particles. In addition, heat treatment of the sample decreased its resistivity [323].

\subsection{High Entropy Alloys (HEAs)}

High entropy alloys (HEAs) with a large compositional design space represent a new paradigm of structural alloy consisting of five or more principal elements, each having with a between 5 to 35 atomic \% (at.\%). The large compositional design space of HEAs offers a unique flexibility to tailor their mechanical and functional properties for different applications. The core effects of high configurational entropy, lattice distortion, cocktail effect, and sluggish diffusion lead to a gamut of attractive mechanical, corrosion, and oxidation properties [328-339]. Therefore, they have been attracted as potential materials for advanced applications including aerospace, nuclear, cryogenics, and medical [340-342]. 
The fabrication of HEAs with homogeneous microstructure and in complex geometries using conventional techniques is challenging. There has been a growing interest in AM of HEAs during most recent years; this section summarizes the state of the art in AM of HEAs.

4.6.1. Microstructural Characterization of Powder Bed Fusion Additive Manufactured HEAs

Electron Beam Processed HEAs

Few reports have been published on the fabrication of HEAs using selective electron beam melting (SEBM) [343-347]. Fujieda et al. [343], Kuwabara et al. [344], and Shiratori et al. [345], successfully fabricated an equiatomic AlCoCrFeNi HEA using SEBM. The nano-lamellar morphology consisted of mixture of FCC + BCC + B2 was observed in their work for SEBM-built HEA due to preheating; however, the raw powder and as-cast counterpart showed a BCC + B2 structure. The FCC was formed mostly at grain boundaries and its density was higher at the bottom of the sample than the top part, which may be attributed to longer preheating, which resulted in a phase transformation from the BCC phase to FCC. The amount of B2 was also noticeable in the bottom part. The columnar grain along build direction with the orientation of $\langle 100\rangle$ was observed in top part of the SEBM sample, while equiaxed grains with a random orientation similar to the as-cast sample, were found in the bottom. The higher cooling rate of the SEBM process led to it having a smaller grain size than the as-cast one. Moreover, cellular microstructure was observed only in SEBM sample. Elemental distribution of both the as-cast and SEBM alloys showed elemental fluctuation inside the grains, as well as the segregation of $\mathrm{Fe}$ and $\mathrm{Co}$ at the grain boundaries. Fe and $\mathrm{Cr}$ were also segregated at sub-grain boundaries. The same microstructure was reported for CoCrFeMnNi HEA fabricated using EBM [346]. Wang et al. [346] noted the hierarchical microstructure combining large columnar grains along build direction with a strong $<100>$ texture and cellular structure (dendritic) for EBMbuilt $\mathrm{CoCrFeMnNi} \mathrm{HEA}$. The equiaxed grains with intragranular cellular microstructures (dendritic) were visible perpendicular to the build direction. They found segregation of $\mathrm{Fe}, \mathrm{Cr}$, and $\mathrm{Co}$ into the dendrites, whereas $\mathrm{Mn}$ and $\mathrm{Ni}$ segregated into the interdendrite regions. The microstructure characterization of $\mathrm{Co}_{1.5} \mathrm{CrFeNi}_{1.5} \mathrm{Ti}_{0.5} \mathrm{Mo}_{0.1}$ HEA fabricated using EBM revealed needle-like $\mathrm{Ni}_{3} \mathrm{Ti}$ intermetallic phases with basket-weave morphology precipitated homogeneously in the matrix, which was dissolved during solution treatment and a nano-sized particulate single-cubic-ordering phase was precipitated due to the spinodal decomposition [348]. Popov et al. [347] tried to manufacture $\mathrm{Al}_{0.5} \mathrm{CrMoNbTa}_{0.5} \mathrm{HEA}$ using a blend of elemental powders using the SEBM technique, and reported that it can be possible through the optimization of the process parameters.

\section{Laser-Processed HEAs}

Due to metastable nature of HEAs, their additive manufacturing is challenging, and the as-built samples usually have defects such as crack, pores and balling. Several parameters such as powder composition and laser processing parameters need to be optimized to obtain HEA samples free of any defects. Studies on the effect of VED on quality parts of SLM-built HEAs showed that low VED increased the probability of cracking, porosity and delamination between the successive layers. Balling can happen in insufficient VED or high scanning speed [349]. An adequate amount of VED at relatively slow scan speed improved the molten pool flowability, as well as layer-by-layer bonding and densification. However, high VED resulted in scattering of molten metals and key-hole porosity [350]. Therefore, an optimized range of VED is required to fabricate defect-free parts which, is shown for two HEAs in Figure 10 [351]. 


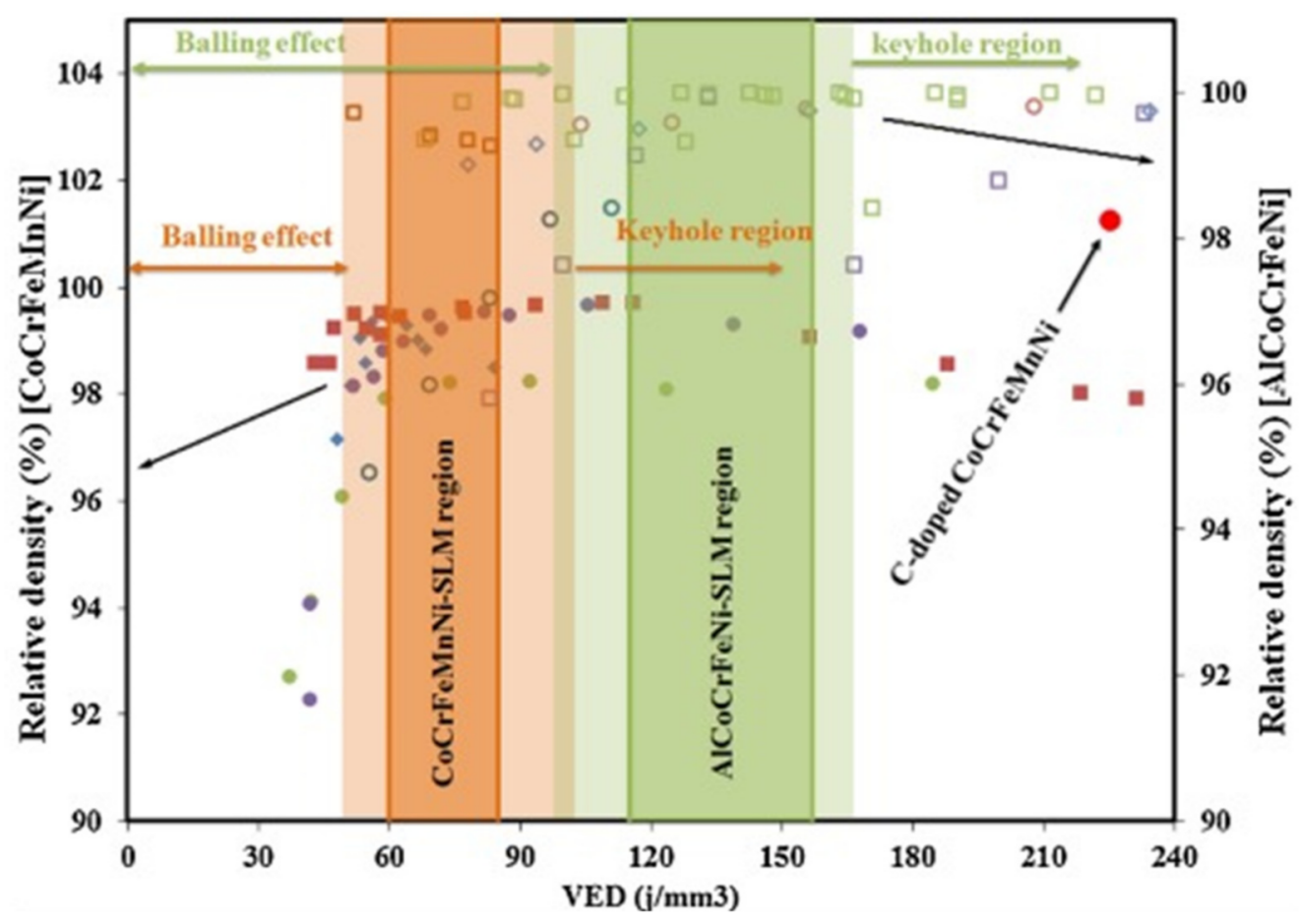

Figure 10. Relative densities of $\mathrm{CoCrFeMnNi}$ and $\mathrm{AlCoCrFeMnNi}$ HEA fabricated using SLM as a function of VED, indicating the range in which balling, keyhole porosity, and sound printing can happen. Solid and open symbols denoted as to the density of CoCrFeMnNi and AlCoCrFeMnNi HEA, respectively. Reprinted with permission from ref. [351]. Copyright 2021 Elsevier.

SLM-fabricated AlCoCrFeNi HEA showed a dual phase structure consisting of epitaxial growth of columnar disordered BCC phases and ordered BCC phases (B2) precipitated between them [352,353]. An increase in VED led to an increase in a fraction of the B2 phase [352]. The chemical composition of the powder also has critical effect on the quality and morphology of the final part. The microstructure of $\mathrm{AlCrCuFeNix} \mathrm{HEA} \mathrm{manufactured}$ using SLM changed from columnar structure to equiaxed grains, with an increase in $\mathrm{Ni}$ content [354]. Samples without cracks can be fabricated at $x=3$. The SLM-built AlCrCuFeNi3.0 HEA exhibited heterogeneous microstructures composed of nano-sized lamellar dual-phase (FCC + B2) structures, twins, and the coherently precipitated BCC nanophase within the B2 phase [354]. Lin et al. [355] reported that the SLM-printed CoCrFeNi HEA had columnar grain microstructure with cellular structures and large number of dislocations at grain boundaries, as shown in Figure 11a,b [355]. Annealing at $1300^{\circ} \mathrm{C}$ for $2 \mathrm{~h}$ led to a change in microstructure to equiaxed grains, as shown in Figure 11c. Twining was also formed after annealing (Figure 12a,b) [355].
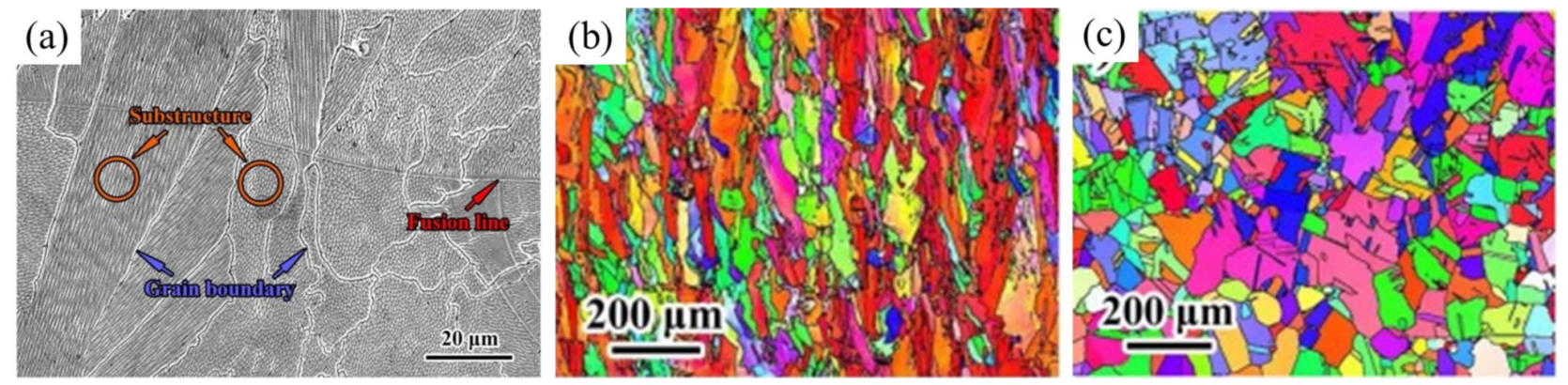

Figure 11. (a) SEM images of SLM-built CoCrFeNi HEA showing its cellular structure; EBSD of CoCrFeNi HEA in (b) asbuilt and (c) annealed conditions, confirming columnar microstructure for as-built and equiaxed for annealed sample. Reprinted with permission from ref. [355]. Copyright 2021 Elsevier. 


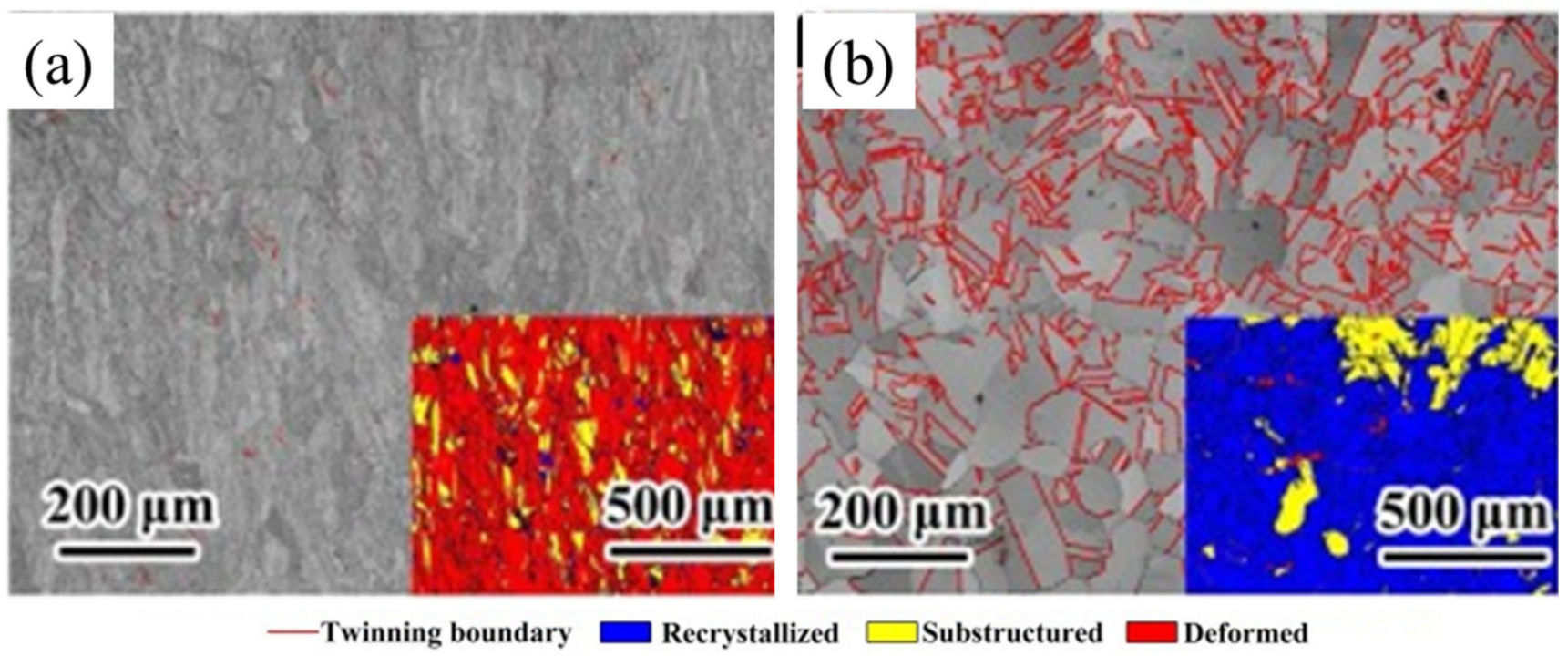

Figure 12. Distribution of twinning for CoCrFeNi HEA in (a) as-built and (b) annealed at $1300{ }^{\circ} \mathrm{C}$ for $2 \mathrm{~h}$ conditions, indicating higher density of twinning after annealing. Insets show recrystallization distribution map. Reprinted with permission from ref. [355]. Copyright 2021 Elsevier.

The most common HEA used for powder based additive manufacturing was CoCrFeMnNi. This alloy showed FCC crystal structure in both as-cast and SLM-built conditions [356-358]. There are controversial results about the microstructure of SLM-built $\mathrm{CoCrFeMnNi}$. Some authors reported the columnar microstructure of the alloy along the build direction $[359,360]$ and some reported the mixed morphology composed of columnar and equiaxed grains [357]. For example, Tong et al. [357] worked on manufacturing of equiatomic CoCrFeMnNi HEAs using laser-based AM at laser power in the range of $600-1000 \mathrm{~W}$. They found that higher laser powder led to a decrease in porosity and increase in density of sample. The as-built alloy showed mixed epitaxial grown columnar grain and equiaxed grain microstructure [357]. The columnar grains' size increased from $2 \mu \mathrm{m}$ to $7 \mu \mathrm{m}$ with increase in laser power from $600 \mathrm{~W}$ to $1000 \mathrm{~W}$. The same microstructure was observed in a study carried out by Chew et al. [358]. After heat treatment at $1100{ }^{\circ} \mathrm{C}$, the microstructure changed to recrystallized grain structure [357]. Cellular structure was also reported by some authors [361,362]. In two works carried out by Xu et al. [361,362] uniform composition and numerous fine cellular subgrains with the grain boundary angles less than $5^{\circ}$ were observed in the SLM-built CoCrFeMnNi HEA, while the as-cast sample consisted of coarse dendrite crystals. In another study, Li et al. [356] reported huge dislocation pile-ups, nanotwins, tetragonal $\sigma$ phase, lattice distortion and Mn segregation at the boundaries of the melt pool in the microstructure characterization of $\mathrm{CoCrFeMnNi}$, prepared using SLM.

Zhu et al. [363] fabricated fully dense interstitial carbon strengthened $\mathrm{Fe}_{49.5} \mathrm{Mn}_{30} \mathrm{Co}_{10} \mathrm{Cr}_{10} \mathrm{C}_{0.5} \mathrm{HEA}$, exhibiting a hierarchical microstructure with various length scale using SLM. The feasibility of fabricating another interstitial carbon strengthened HEA, $(\mathrm{CoCrFeMnNi})_{99} \mathrm{C}_{1}$ HEA, using SLM was studied by Park et al. [364,365]. The alloy was able to be successfully manufactured at scanning speed of 200 and $600 \mathrm{~mm} / \mathrm{s}$. In a similar study, Zhoe et al. analyzed the effect of processing parameter on fabrication of $\mathrm{FeCoCrNiC}_{0.05} \mathrm{HEA}$ [366-368]. They reported that the dense sample with columnar and cellular microstructure with M23C6 nano carbides precipitated at grain boundary and dislocation networks can be obtained at scanning power of $400 \mathrm{~W}$ or scanning speed of $800 \mathrm{~mm} / \mathrm{s}$. 
4.6.2. Mechanical Properties of Powder Bed Fusion Additive Manufactured HEAs Electron Beam Processed HEAs

The mechanical properties of HEAs fabricated using EBM was studied by several researchers. In a work conducted by Wang et al. [346], the EBM-built CoCrFeNiMn HEA parts displayed similar tensile properties as their conventional cast counterpart. The deformation mechanism was found to be dislocation and small contribution of twinning [346]. In another study, the EBM-built AlCoCrFeNi HEA showed relatively lower strength and ductility than its as-cast counterpart, as shown in Figure 13 [343]. The fracture strength was above $1400 \mathrm{MPa}$ for SEBM samples, which is six times higher than a conventional engineering material SUS304. In addition, superior properties were observed for samples whose cylinder axes were parallel to the build direction and for the samples in which cylinder axes were perpendicular to the build direction, confirming its anisotropic behavior [343]. Fujieda et al. [348] found higher tensile strength and ductility in heat-treated EBM-built $\mathrm{Co}_{1.5} \mathrm{CrFeNi}_{1.5} \mathrm{Ti}_{0.5} \mathrm{Mo}_{0.1} \mathrm{HEA}$ superior to the as-cast sample.

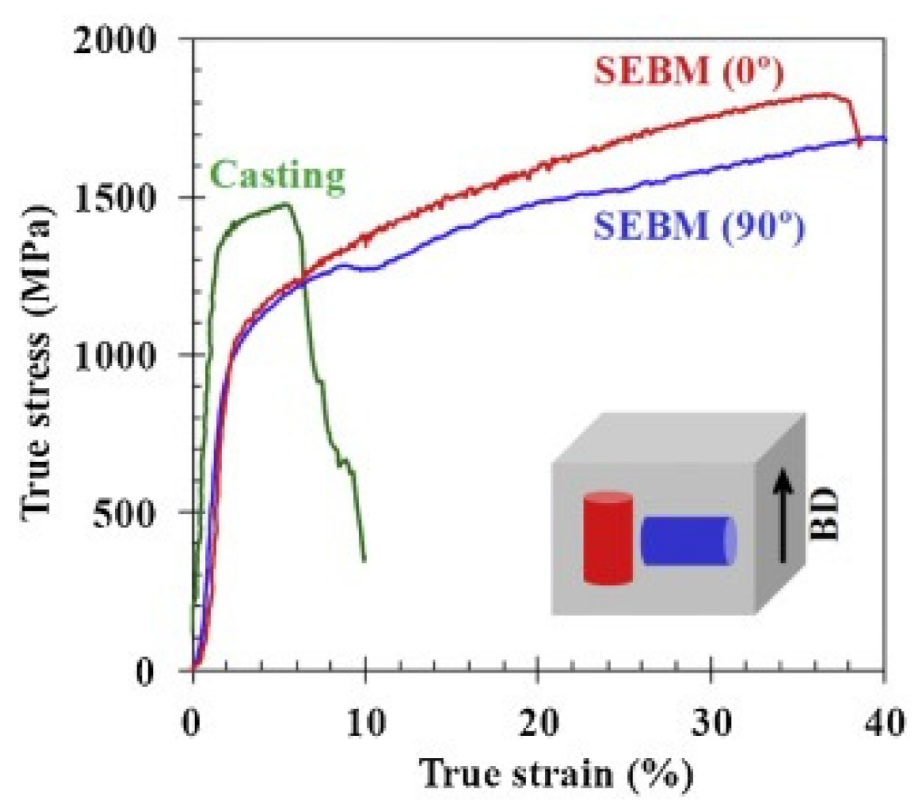

Figure 13. True stress-strain plot of AlCoCrFeNi HEA fabricated using selective electron beam melting (SEBM) for samples whose cylinder axes were parallel (SEBM $\left(0^{\circ}\right)$ ) and perpendicular to the build direction (SEBM $\left(90^{\circ}\right)$ ) and compared with as-cast sample. Reprinted with permission from ref. [343]. Copyright 2021 Elsevier.

\section{Laser-Processed HEAs}

HEAs fabricated using SLM exhibited outstanding strength and ductility superior to their conventionally fabricated and post-processed counterpart and comparable to the conventional materials such as stainless steel [351,356,369-372]. The tensile and compressive strength of CoCrFeMnNi HEA has been investigated by many researchers [356,372-375]. Yield strength in the range of $500-700 \mathrm{MPa}$ and strain of $40-70 \%$ was reported. The laserprocessed CoCrFeMnNi HEA exhibited superior microhardness and mechanical properties to its corresponding arc-melting specimen at different temperatures. Laser power had a negligible effect on microhardness and tensile properties. Grain refinement and grain boundary strengthening was the dominating mechanism for higher strength of laser-melted CoCrFeMnNi HEAs due to Hall-Petch relationship [358,376]. Twinning was proved to be a strengthening mechanism at low temperatures. The morphology of the sample after tensile test at $25^{\circ} \mathrm{C}$ and $-130{ }^{\circ} \mathrm{C}$ exhibited $<100>$ and $<111>$ as the main grain orientations along tensile axis [358]. Heat treatment of the sample led to improvements in its ductility due to residual stress releases while retaining high strength [357]. 
Fujieda et al. [371] found SLM-built $\mathrm{Co}_{1.5} \mathrm{CrFeNi}_{1.5} \mathrm{Ti}_{0.5} \mathrm{Mo}_{0.1}$ HEA exhibited excellent tensile strength of $1178.0 \mathrm{MPa}$ and elongation of $25.8 \%$ due to smaller grain size and the homogenous structure without any intermetallic compounds, which was further improved after post-heat treatment [371]. In another studies, superior mechanical properties of $\mathrm{Al}_{0.3} \mathrm{CoCrFeNi}$ and $\mathrm{Al}_{0.5} \mathrm{CoCrFeNi} \mathrm{HEA}$ fabricated by SLM were reported by [377-379]. The ductility of AlCrCuFeNi ${ }_{x}$ HEA manufactured using SLM improved with the increase in Ni content [354]. A combination of high strength and ductility was reported for $\mathrm{AlCrCuFeNi}_{3.0}$ [354] and $\mathrm{AlCrFeNiV} \mathrm{[380]} \mathrm{HEAs} \mathrm{due} \mathrm{to} \mathrm{their} \mathrm{heterogeneous} \mathrm{microstruc-}$ ture. Agrawal et al. studied mechanical properties of SLM-built $\mathrm{Fe}_{40} \mathrm{Mn}_{20} \mathrm{Co}_{20} \mathrm{Cr}_{15} \mathrm{Si}_{5} \mathrm{HEA}$ representing excellent tensile strength of $\sim 1.1 \mathrm{GPa}$ and ductility of $30 \%$, which were higher than those of its as-cast counterpart attributed to high work hardenability and the uniform strain accommodation of $\varepsilon$-hcp and $\gamma$-FCC phases through non-basal activity, as well as transformation and twinning-induced plasticity [381]. SLM-built FeCoCrNi showed an average microhardness of $220 \mathrm{HV}$, which decreased gradually to $140 \mathrm{HV}$ after annealing at $1300{ }^{\circ} \mathrm{C}$ may be attributed to the decrease in residual stress after annealing and decrease in dislocation density [355]. The tensile and yield strength of the alloy also decreased by $60 \%$ and $10 \%$, respectively, but elongation and impact toughness increased after annealing.

Interstitial solute strengthened high entropy alloy, $\mathrm{Fe}_{49.5} \mathrm{Mn}_{30} \mathrm{Co}_{10} \mathrm{Cr}_{10} \mathrm{C}_{0.5}$ (at.\%), fabricated using SLM, showed an enhanced strength-ductility combination, superior to the as-cast sample [363]. The deformation mechanisms at different stages of straining were reported to be dislocation slip, deformation twinning, phase transformation, stacking faults (SFs) and slip bands. The same result was reported for SLM-built (CoCrFeMnNi) ${ }_{99} \mathrm{C}_{1}$ HEA showing excellent mechanical properties due to the simultaneous activation of multiple strengthening mechanisms such as grain refinement, interstitial solid solution, dislocation pile-ups and nano-scale solute heterogeneities [364,365]. The C-doped HEAs showed lower ductility than the as-cast sample [368,369], while simultaneous strength and ductility in $\mathrm{N}$-doped HEAs were reported in [382], due to their hierarchical structures consisting of dislocation structures, low angle boundaries and bimodal grain size.

\subsubsection{Corrosion Behavior of Powder Bed Fusion Additive Manufactured HEAs Electron Beam Processed HEAs}

The corrosion properties of EBM-built HEAs are rarely studied. In one study, the corrosion resistance of $\mathrm{AlCoCrFeNi}$ fabricated using EBM was inferior to that of austenite stainless steel due to solute partitioning in EBM samples [344]. In another study carried out by Fujieda et al. [348], the solution-treated SEBM Co ${ }_{1.5} \mathrm{CrFeNi}_{1.5} \mathrm{Ti}_{0.5} \mathrm{Mo}_{0.1} \mathrm{HEA}$ specimens exhibited high pitting potential due to the uniform composition and homogeneous precipitation of the very fine particulate ordering phase.

\section{Laser-Processed HEAs}

Ren et al. [383] reported the superior corrosion resistance of SLM-built CoCrFeMnNi HEA compared to its arc-melted counterpart because of the homogeneous elemental distribution and lower density of micro-pores in SLM sample acting as local anodic sites and inhibiting the nucleation and growth of new pits. In a similar study, the corrosion behavior of CoCrFeMnNi HEA manufactured using SLM in $3.5 \mathrm{wt} . \% \mathrm{NaCl}$ solution was studied by $\mathrm{Xu}$ et al. [361]. They found that a more stable and stronger passive film with fewer defects formed on the SLMed HEA than on the as-cast sample. Lower corrosion current density and higher corrosion potential were also observed for SLM-built sample indicating its better corrosion resistance due to grain refining and the homogenous composition. High density of grain boundaries may trigger passive film formation and homogenous structure diminish galvanic corrosion. The main corrosion mechanism was reported to be the pitting and local corrosion due to $\mathrm{Cl}-$ ions. Lower density and smaller pits were formed on SLMed sample. SLM-built AlCoFeNiSm $0.1 \mathrm{~V}_{0.9}, \mathrm{AlCoFeNiSm}_{0.1} \mathrm{TiV}_{0.9}$ and $\mathrm{AlCoFeNiSm}_{0.05} \mathrm{TiV}_{0.95} \mathrm{Zr}$ HEAs showed low corrosion rates in $3.5 \mathrm{wt} . \% \mathrm{NaCl}$ solution without pitting corrosion. In addition, $\mathrm{AlCoFeNiV}_{0.9} \mathrm{Sm}_{0.1}$ and $\mathrm{AlCoFeNiSm}{ }_{0.1} \mathrm{TiV}_{0.9}$ HEA fabricated using SLM exhibited good 
corrosion performances at elevated temperatures [384]. Zhang et al. [385] reported the corrosion current density of SLM-built RHEAs to be two orders of magnitude lower than the 316L SS due to easy passivation of $\mathrm{Mo}, \mathrm{Nb}$, and Ta elements.

\subsection{Bulk Metallic Glasses (BMGs)}

Bulk metallic glasses are a new type of metallic materials which have attracted considerable attention over the past decades in the field of structural applications due to their outstanding mechanical properties such as high strength, large elastic limit, excellent irradiation, wear and corrosion resistance in the glassy state and thermoplastic forming ability in the supercooled liquid state [386,387]. However, they have a limited industrial application owing to the insufficient dimensions and geometries achievable using current manufacturing techniques. Additive manufacturing holds the potential to enable the manufacturing of large-scale bulk metallic glass components with complex geometries. The first attempt to used SLM to fabricate fully amorphous BMG components under the appropriate conditions was carried out by Pauly et al. [388] in 2013. Since then, several other BMGs based on Fe [388-396], Al [397-400], Zr [401-414], Cu [415,416], Pd [417], and Ti [418] have been fabricated using the laser PBF process. A sample made of Fe-based BMGs as large as $45 \mathrm{~mm}$ in diameter and $20 \mathrm{~mm}$ in length was fabricated by Wang et al. [419]. SLM is most popular and widely investigated powder bed fusion additive manufacturing technique to fabricate BMGs so far. Therefore, the following section focuses on the microstructure and properties observed in BMGs prepared by this technique.

4.7.1. Microstructural Characterization and Part Quality of Powder Bed Fusion Additive Manufactured BMGs

Even though the samples prepared using SLM are amorphous to some extent, there might be some local structural heterogeneities in glassy phase owing to different thermal histories at different locations during processing. Structural differences, such as different short range ordering (SRO), were reported for SLM-prepared BMGs between the melt pool area and heat affected zone (HAZ) due to the complex thermal history [414]. Partial crystallization in HAZs may occur as a result of devitrification of the previously formed amorphous phase due to repeated laser scanning in the SLM process, resulting in composition and structural differences. The crystallization kinetic of BMG fabricated using SLM may also differ from the as-cast sample due to partially crystallized HAZ and the relaxation of the melt pool. For example, the amorphous alloys prepared using SLM exhibited lower thermal stability than the as-cast samples attributed to the pre-existing crystalline in the SLMed sample [403]. In another study, Best et al. [420] observed a small elliptical distortion in the two-dimensional diffraction patterns of an SLM-built Zr-based BMG $\left(\mathrm{Zr}_{59.3} \mathrm{Cu}_{28.8} \mathrm{Nb}_{1.5} \mathrm{Al}_{10.4}\right)$ along the building direction, indicating variation in local strain at different positions. These local strain variations may be attributed to the variation in atomic arrangement and the medium-range order $(\mathrm{MRO})$ in the glass confirming by slight shifts in the structure function $S(Q)$ and in $G(r)$ (reduced pair distribution function).

Jung et al. [393] used SLM to manufacture fully amorphous FeCSiBPCrMoAl samples with high density of $99.7 \%$. Micro-pores and fine cracking caused by the temperature gradient between processed layer and the cold layers below it were observed in the samples. Fully amorphous, dense, and crack-free BMG samples can be fabricated using SLM in a very narrow window. In order to obtain a fully amorphous structure, a high cooling rate is needed. The higher scanning speeds correspond to higher cooling rates, leading to a higher volume fraction of the amorphous phase in SLM-built samples, as was reported for Fe-based BMG in [390,394]. Decreasing scanning speed from $1000 \mathrm{~mm} / \mathrm{s}$ to $200 \mathrm{~mm} / \mathrm{s}$ decreased the glassy volume fraction by 50\% [394]. However, higher scanning speed led to more porosity formation [390,394]. Hatch spacing and layer thickness are two other parameters which affect the structure of BMGs fabricated using SLM. Higher hatch spacing leads to lower density, and on the other hand, lower hatch spacing results in crystallization due to a higher energy density. The crack-free CuZr-based BMG was fabricated using SLM in a work carried out by Gao et al. [416]. The alloy showed amorphous matrix with some B2CuZr 
crystallines phases which became larger at smaller hatch spacing. Larger layer thickness also leads to more glassy fraction, but simultaneously results in more defects [401,412]. Ouyang et al. [394] established a theoretical model to predict the relationship between the SLM process parameters and the volume fraction of the amorphous phase, and found that lower laser energy density led to increase in amorphous structure of the sample, owing to the longer time needed for nucleation and growth. Lu et al. [415] fabricated $\mathrm{Cu}_{50} \mathrm{Zr}_{43} \mathrm{Al}_{7}$ bulk metallic glass via SLM using gas-atomized amorphous powders. The phase characterization of the alloy showed structural relaxation and partial crystallization of the alloy fabricated at laser energy density higher than $>26.4 \mathrm{~J} / \mathrm{mm}^{3}$ and lower than $24 \mathrm{~J} / \mathrm{mm}^{3}$. A nearly fully amorphous structure of Cu-based BMG with nanometer-size crystalline phases was achieved at a laser energy density of $25 \mathrm{~J} / \mathrm{mm}^{3}$. However, Sohrabi et al. [417] found that low volumetric energy density values $\left(<3 \mathrm{~J} / \mathrm{mm}^{3}\right)$ led to higher porosity in SLM-built Pd-based BMGs, and much larger values $\left(>6 \mathrm{~J} / \mathrm{mm}^{3}\right)$ resulted in curved and irregular surfaces due to heat accumulation, which reduces the accuracy of the part. Therefore, optimization of parameters is required to balance between porosity and amorphization.

There are several other studies which focus on optimizing processing parameters to achieve defect-free fully glassy parts. The fully amorphous $\mathrm{Zr}_{52.5} \mathrm{Ti}_{5} \mathrm{Cu}_{17.9} \mathrm{Ni}_{14.6} \mathrm{Al}_{10}$ was fabricated using SLM at laser power of $200 \mathrm{~W}$ and scanning speed of $2000 \mathrm{~mm} / \mathrm{s}$ [401]. At lower scan speed, the crystallization happened due to non-homogeneous distribution of elements. Marattukalam et al. [404] studied the fabrication of another composition of Zr-based BMGs, i.e., $\mathrm{Zr}_{59.3} \mathrm{Cu}_{28.8} \mathrm{Al}_{10.4} \mathrm{Nb}_{1.5}$ BMG using SLM with the focus on optimizing process parameters to obtain fully amorphous structure. They found that the laser power $\leq 75 \mathrm{~W}$ and scanning speed of $2000 \mathrm{~mm} / \mathrm{s}$ resulted in a fully amorphous sample. Cubic phase $\mathrm{Cu}_{2} \mathrm{Zr}_{4} \mathrm{O}$ were observed at samples prepared at a laser power of more than $75 \mathrm{~W}$. However, smaller and lower porosities were also formed at higher laser power due to improvement in powder fusion and larger melt pool. The different laser power value was reported for two Zr-based BMGs at which a fully amorphous sample can be obtained, which may be due to difference in their composition or substrate temperature, and layer thickness during SLM processing. Xing et al. [421] studied the fabrication of $\mathrm{Zr}_{60.14} \mathrm{Cu}_{22.31} \mathrm{Fe}_{4.85} \mathrm{Al}_{9.7} \mathrm{Ag}_{3}$ BMG using SLM with the focus on investigating the effect of energy densities on defect formation. They found that balling happened at energy densities lower than $8.33 \mathrm{~J} / \mathrm{mm}^{3}$ because of incomplete melting of the powder particles; as energy densities increased to $13.89-16.67 \mathrm{~J} / \mathrm{mm}^{3}$, interlayer pores and open pores formed due to incomplete welding and insufficient wetting of the liquid between layers. Further increase in energy densities to $20.83-27.78 \mathrm{~J} / \mathrm{mm}^{3}$ led to formation of fine metallurgical pores resulting from gas escaping from the molten pools while rapid solidification occurred. In another study, nearly dense sample with density more than $99 \%$ was obtained for amorphous $\mathrm{Fe}_{68.3} \mathrm{C}_{6.9} \mathrm{Si}_{2.5} \mathrm{~B}_{6.7} \mathrm{P}_{8.7} \mathrm{Cr}_{2.3} \mathrm{Mo}_{2.5} \mathrm{Al}_{2.1}$ at low scanning speed ( $\left.<2500 \mathrm{~mm} / \mathrm{s}\right)$ and high power $(>300 \mathrm{~W})$ due to optimal energy transfer during processing [393]. The same results on the effect of laser energy density on the density of laser-processed BMGs were reported in [391,422].

In addition to optimizing process parameters, selecting suitable scanning strategy can also reduce the amount of porosity and crack in SLMed BMG components. The double scan strategy is one approach which was used by Nam et al. [422] to increase density and amorphization of $\mathrm{Fe}_{73.7} \mathrm{Si}_{11} \mathrm{~B}_{11} \mathrm{C}_{2} \mathrm{Cr}_{2.28}$ alloy. They concluded that a double scan can reduce porosity in SLM samples due to increases in exposure time of powder to laser leading to reduction in voids, and thus increase in density. Zou et al. [396] used another scanning strategy known as the chessboard scanning strategy in combination with laser re-melting to fabricate micro-crack-free Fe-based bulk metallic glass via selective laser melting (SLM). This scanning strategy can reduce cracks due to decrease in residual stress by adjusting the heat flux direction. Pauly et al. [412] found that among three different scanning strategies, namely fill-line scans, chess-board scans, and unidirectional scans, the chess-board scan resulted in higher porosity, while unidirectional scans led to 
the lowest degree of porosity. In another attempt, Li et al. [400], successfully fabricated $\mathrm{Al}_{85} \mathrm{Ni}_{5} \mathrm{Y}_{6} \mathrm{Co}_{2} \mathrm{Fe}_{2}$ BMGs without cracks by using a high power initial scan followed by a lower power re-scan. The re-scanning can reduce crack formation due to release of initial residual stress through superplasticity formation, as well as decrease the thermal stress result from lowered temperature gradient. The same strategy was applied to Zr-based BMG and fully amorphous dense sample was fabricated using SLM [401].

\subsubsection{Mechanical Properties of Powder Bed Fusion Additive Manufactured BMGs}

Although, BMG produced using SLM showed high hardness, wear resistance, compressive strength, and flexural strength, their properties was mostly inferior or in some cases comparable to their as-cast counterpart $[405,417,423]$. In addition, the SLM-fabricated BMGs showed low plastic strain even lower than their as-cast counterpart. The highest ductility was reported for SLMed $\mathrm{Zr}_{60.14} \mathrm{Cu}_{22.31} \mathrm{Fe}_{4.85} \mathrm{Al}_{9.7} \mathrm{Ag}_{3} \mathrm{BMG}$ with the compressive plastic strain of $\sim 1.4 \%$ [407]. Sohrabi et al. [417] reported the SLM-built Pd-based BMG showing high hardness ( 498 HV1) and compressive strength ( 1138 MPa), which was only slightly lower than the as-cast sample with similar composition, despite the presence of some porosity in the SLM-built sample. Low ductility of $\sim 1.17 \%$ was also observed [417]. Deng et al. [410] studied the mechanical properties of SLM-built $\mathrm{Zr}_{52.5} \mathrm{Cu}_{17.9} \mathrm{Ni}_{14.6} \mathrm{Al}_{10} \mathrm{Ti}_{5}$ indicating its lower compressive yield strength ( 1700 MPa vs. $1800 \mathrm{MPa})$ and ductility $(\sim 0.5 \%)$ as well as comparable microhardness and wear properties to the as-cast sample. The wear mechanism was mentioned as abrasive and adhesive wear for both SLM and as-cast samples.

The flexural strength of the SLM-built $\mathrm{Zr}_{59.3} \mathrm{Cu}_{28.8} \mathrm{Nb}_{1.5} \mathrm{Al}_{10.4} \mathrm{BMG}$ was $1300 \mathrm{MPa}$ which was $\sim 33 \%$ lower than the laboratory grade cast sample and its fracture toughness was $\sim 80 \%$ lower than the as-cast counterpart [423]. The SLM sample also showed higher embrittlement due to porosity in the sample, which acts as a stress concentration point [409]. The more brittle nature of SLM-fabricated $\mathrm{Zr}_{59.3} \mathrm{Cu}_{28.8} \mathrm{Nb}_{1.5} \mathrm{Al}_{10.4} \mathrm{BMG}$ compared to ascast alloy may also be attributed to dissolved oxygen content in as-printed sample which led to a decrease in atomic mobility and thus increase in the activation energy for shear transformations initiation, confirmed by lack of load drops before the yielding in micropillar compression test $[408,423]$. The printed alloy showed comparable wear properties to the as-cast sample, with the printed sample slightly superior at higher load of $500 \mathrm{~g}$. The Vickers hardness was also comparable ( 466 HV) [409]. The hardness and Young's modulus of SLM-built alloy increased as laser power increased attributed to formation of harder crystalline phases acting as barriers to shear band formation and propagation resulting in increase in hardness. The increase in Young's modulus may be due to the reduction in average interatomic distance and higher strength in atomic bonding after partial crystallization [404]. The anisotropic mechanical behavior was observed for $\mathrm{CuZr}$ BMG made using SLM. The alloy showed fracture strength of $\sim 0.95 \mathrm{GPa}$ along the loading direction perpendicular to the building direction, which decreased to a lower value along the loading direction parallel to the building direction [416]. The fracture toughness values for the most Zr-based BMGs fabricated using SLM were in the range of $20-36 \mathrm{MPa} \mathrm{m}^{1 / 2}$, comparable to the toughness of commercial aluminum alloy and lower than that of the stainless steel and Ti-6Al-4V alloys [407,408,424].

Some studies reported the effect of processing parameter on properties of SLM-built BMGs. For example, Nong et al. [391] reported that the nanohardness of $\mathrm{Fe}_{54.35} \mathrm{Cr}_{18.47} \mathrm{Mn}_{2.05} \mathrm{Mo}_{13.93} \mathrm{~W}_{5.77} \mathrm{~B}_{3.22} \mathrm{C}_{0.90} \mathrm{Si}_{1.32}$ increased from 11.2 GPa to $13.5 \mathrm{GPa}$ with an increase in laser power or laser energy density, and became less scattered due to a reduction in porosity and crack in the sample. The $\mathrm{Al}_{86} \mathrm{Ni}_{6} \mathrm{Y}_{4.5} \mathrm{Co}_{2} \mathrm{La}_{1.5} \mathrm{MG}$ fabricated using SLM at a laser power of $200 \mathrm{~W}$ showed hardness value of $4.7 \mathrm{GPa}$ and modulus of $100 \mathrm{GPa}$ (at $2 \mathrm{mN}$ load) in build direction and at the center of the melt pool; however, the hardness and modulus decreased to 3.8 GPa and $70 \mathrm{GPa}$, respectively, at the lowest laser power of $80 \mathrm{~W}$. Perpendicular to the build direction, the highest hardness was found with a laser power of $120 \mathrm{~W}$, which was $\sim 4.6 \mathrm{GPa}$ at the center and $\sim 4.0 \mathrm{GPa}$ at the edge, and the 
lowest value was at a laser power of $80 \mathrm{~W}$, i.e., 4.0 GPa at the center and $\sim 3.1 \mathrm{GPa}$ at the edge [399]. Li et al. [401] found the SLM-built $\mathrm{Zr}_{52.5} \mathrm{Ti}_{5} \mathrm{Cu}_{17.9} \mathrm{Ni}_{14.6} \mathrm{Al}_{10} \mathrm{BMG}$ exhibiting a hardness of $5.5 \mathrm{GPa}$ and compressive strength of $0.6 \mathrm{GPa}$ at a scanning speed of $500 \mathrm{~mm} / \mathrm{s}$ and power of $200 \mathrm{~W}$ which increased to $6.5 \mathrm{GPa}$ and $1.5 \mathrm{GPa}$, respectively, as scanning speed increased to $2000 \mathrm{~mm} / \mathrm{s}$ due to the fully amorphous nature of sample. Multiple scans increased the hardness and strength of the as-built sample due to reduction in free volume. The alloy showed negligible ductility [401].

The addition of a secondary phase may also improve properties of BMGs fabricated using SLM. SLM-built Fe-based BMGs exhibited low strength (106 MPa) and fracture toughness $\left(2.2 \mathrm{MPa} \cdot \mathrm{m}^{1 / 2}\right)$ which were increased to $780 \mathrm{MPa}$ and $47 \mathrm{MPa} \cdot \mathrm{m}^{1 / 2}$, respectively, through $50 \mathrm{wt} . \%$ addition of ductile $\mathrm{Cu}$. With the addition of $50 \mathrm{wt} \% \% \mathrm{CuNi}$, the strength of Fe-BMG composites increased to an even higher value of $1452 \mathrm{MPa}$; however, fracture toughness decreased to $\sim 38 \mathrm{MPa} \cdot \mathrm{m}^{1 / 2}$ as shown in Figure 14 [392]. In another study, SLMfabricated Al-based BMG composed of intermetallic phases showed a high compressive strength of 1-0.5 GPa from room temperature to $573 \mathrm{~K}$ due to mechanisms such as interfacial strengthening, crack arrest and initiation of new cracks, crack deflection phenomena and confinement phenomena [398].

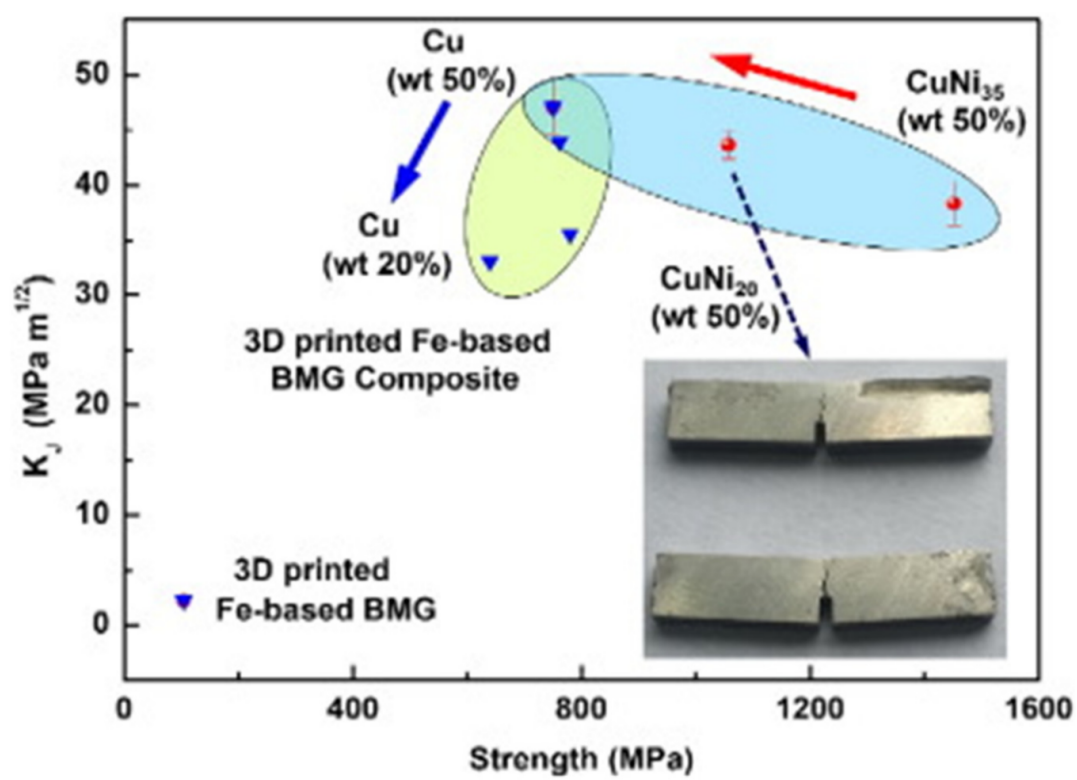

Figure 14. Fracture toughness and strength of 3D printed Fe-based bulk metallic glass composites showing effect of second phase on their properties. Reprinted with permission from ref. [392]. Copyright 2021 Elsevier.

\subsubsection{Corrosion Behavior of Powder Bed Fusion Additive Manufactured BMGs}

The corrosion properties of PBF-AM-built BMGs have rarely been studied. Deng et al. [410] reported the corrosion properties of $\mathrm{Zr}_{52.5} \mathrm{Cu}_{17.9} \mathrm{Ni}_{14.6} \mathrm{Al}_{10} \mathrm{Ti}_{5}$ fabricated using SLM in $0.01 \mathrm{M} \mathrm{Na}_{2} \mathrm{SO}_{4}$ and $0.1 \mathrm{M} \mathrm{NaCl}$ electrolyte was comparable to its as-cast counterpart. The SLM samples exhibited a slightly reduced pitting corrosion susceptibility, and an improved ability for surface healing may be due to better homogeneity of the additively manufactured glass. It was reported that structural defects in as-cast sample representing chemical discontinuities with sharp phase boundaries to the glassy matrix were more detrimental for its corrosion resistance than pore defects in the SLM sample, which are a geometry defect [410]. In another study, the corrosion rate of SLMed Zr-based $\mathrm{BMG}\left(\mathrm{Zr}_{60} \mathrm{Fe}_{10} \mathrm{Cu}_{20} \mathrm{Al}_{10}\right)$ was higher than the as-cast sample and increased with an increase in exposure time due to crystallization and lower amorphous content [402].

Tables 1 and 2 summarize the microstructure and properties of additively manufactured alloys in comparison with their traditionally fabricated parts. 


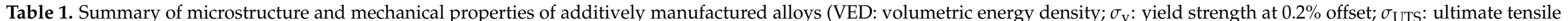

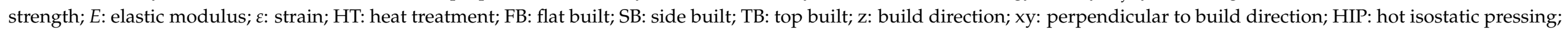

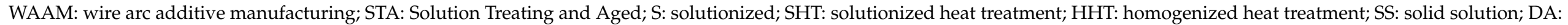
double aging; Q: quenched; C: compressive).

\begin{tabular}{|c|c|c|c|c|c|c|c|c|}
\hline Alloys & Process Method & $\begin{array}{l}\text { VED } \\
\left(\mathrm{J} / \mathrm{mm}^{3}\right)\end{array}$ & Morphology & Phases & $\sigma_{\mathrm{y}}(\mathrm{MPa})$ & $\sigma_{\text {UTS }}(\mathrm{MPa})$ & $E(\mathrm{GPa})$ & $\varepsilon(\%)$ \\
\hline \multirow{12}{*}{$\begin{array}{c}\text { Ti-6Al-4V } \\
{[49-52,57,58,67,68,75,77,82,83,94,96-99,425]}\end{array}$} & \multirow{3}{*}{ EBM } & & $\begin{array}{l}\text { Acicular/ } \\
\text { Lamellar }\end{array}$ & $\alpha+\beta$ & $750-1150$ & $800-1200$ & & $2-25$ \\
\hline & & & Columnar/Basket-weave & $\alpha+\beta$ & $\begin{array}{l}850 \text { (FB) } \\
800 \text { (SB) } \\
720 \text { (TB) }\end{array}$ & $\begin{array}{l}920(\mathrm{FB}) \\
850(\mathrm{SB}) \\
760 \text { (TB) }\end{array}$ & $\begin{array}{l}130 \text { (FB) } \\
115 \text { (SB) } \\
115 \text { (TB) }\end{array}$ & $\begin{array}{l}25 \text { (FB) } \\
20 \text { (SB) } \\
45 \text { (TB) }\end{array}$ \\
\hline & & & Columnar/Fine lamellar & $\alpha / \alpha^{\prime}+\beta$ & 830 & 915 & 118 & 13.1 \\
\hline & $\mathrm{EBM}+\mathrm{HIP}$ & & Columnar/ Coarser lamellar & $\alpha+\beta$ & 795 & 870 & 117 & 13.7 \\
\hline & \multirow[b]{2}{*}{ Laser } & & Lamellar & $\alpha / \alpha^{\prime}+\beta$ & 820 & 950 & & 7 \\
\hline & & $11-83$ & Acicular/Lamellar & $\alpha^{\prime}$ & & & & \\
\hline & Laser + HT & 87 & Columnar/Lamellar & $\alpha+\beta$ & $760-1118$ & $840-1123$ & $112-115$ & $5.36-14$ \\
\hline & Laser + HIP & $67-167$ & Columnar & $\alpha+\beta$ & 950-1000 & $1000-1100$ & & $12-15$ \\
\hline & WAAM & & Lamellar & $\alpha$ & & & & \\
\hline & As-cast & & Lamellar & $A+\beta$ & 700 & 850 & & 4 \\
\hline & Wrought & & Acicular/Equiaxed & $\alpha+\beta$ & $850-1220$ & $900-1290$ & & $10-14$ \\
\hline & Wrought + anneal & & Equiaxed & & 790 & 870 & 104 & 18.1 \\
\hline Ti-24Nb-4Zr-7.9Sn [66] & EBM & & Columnar/Lamellar & $\alpha^{\prime \prime}+\beta$ & & & & \\
\hline Ti-47Al-2Nb-2Cr [63] & EBM & & Lamellar & $\alpha_{2}-\mathrm{Ti}_{3} \mathrm{Al}+\gamma-\mathrm{TiAl}$ & 1400 & & & \\
\hline Ti-47Al-2Cr-2Nb [70] & EBM & & Lamellar/Basket-weave & $\left.\alpha_{2}-\mathrm{Ti}_{3} \mathrm{Al}\right) / \gamma-\mathrm{TiAl}+\mathrm{B}_{2}$ & & & & \\
\hline Ti-48Al-2Cr-2Nb [71] & EBM & $2-430$ & Columnar/Lamellar & $\alpha_{2}+\gamma+\beta$ & & & & \\
\hline \multirow{2}{*}{ Ti-6Al-2Sn-4Zr-6Mo [81] } & Laser & $28-58$ & Columnar & $\alpha^{\prime \prime}+\beta$ & $480-550$ & 1200 & & $25-27$ \\
\hline & Laser + HT & $28-58$ & Lamellar & $\alpha+\beta$ & 1000 & 1100 & & 15 \\
\hline \multirow{2}{*}{ Ti-5Al-5V-5Mo-3Cr [85] } & Laser & & Columnar & $\beta$ & 800 & 1000 & & \\
\hline & Laser + HT & & Columnar & $\alpha+\beta$ & 1000 & 1600 & & 22 \\
\hline
\end{tabular}


Table 1. Cont.

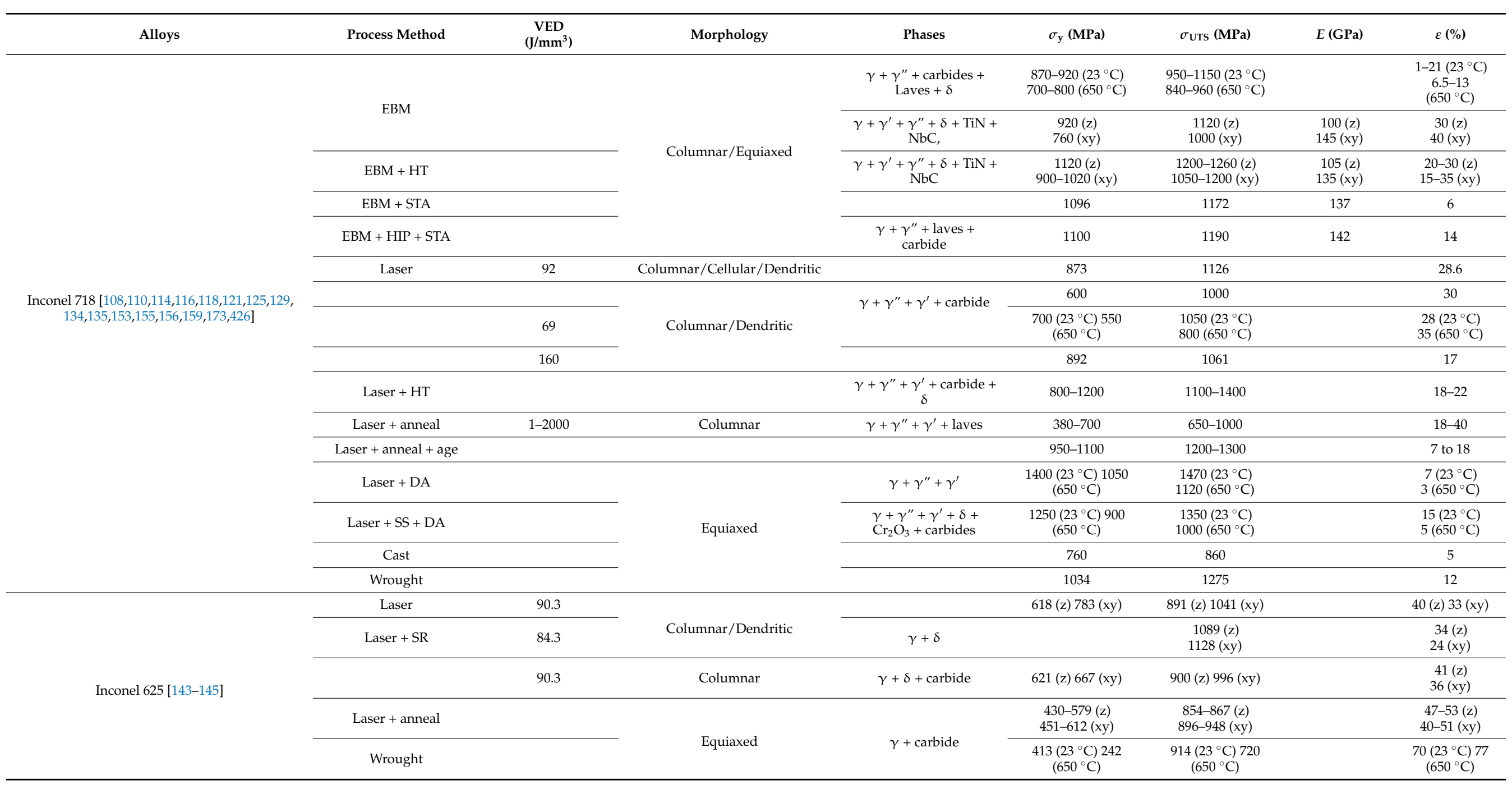


Table 1. Cont.

\begin{tabular}{|c|c|c|c|c|c|c|c|c|}
\hline Alloys & Process Method & $\begin{array}{l}\text { VED } \\
\left(\mathrm{J} / \mathrm{mm}^{3}\right)\end{array}$ & Morphology & Phases & $\sigma_{\mathrm{y}}(\mathrm{MPa})$ & $\sigma_{\text {UTS }}(\mathrm{MPa})$ & $E$ (GPa) & $\varepsilon(\%)$ \\
\hline \multirow{4}{*}{ Inconel 939 [146] } & Laser & \multirow{3}{*}{ 143-206 } & Columnar/Equiaxed & & $\begin{array}{c}650\left(23^{\circ} \mathrm{C}, \mathrm{z}\right) 750 \\
\left(23^{\circ} \mathrm{C}, \mathrm{xy}\right) 700 \\
\left(750^{\circ} \mathrm{C}, \mathrm{xy}\right)\end{array}$ & $\begin{array}{c}900\left(23^{\circ} \mathrm{C}, \mathrm{z}\right) 950 \\
\left(23^{\circ} \mathrm{C}, \mathrm{xy}\right) 720 \\
\left(750{ }^{\circ} \mathrm{C}, \mathrm{xy}\right)\end{array}$ & & $\begin{array}{l}12\left(23^{\circ} \mathrm{C}, \mathrm{z}\right) \\
24\left(23^{\circ} \mathrm{C}, \mathrm{xy}\right) \\
2\left(750^{\circ} \mathrm{C}, \mathrm{xy}\right)\end{array}$ \\
\hline & Laser + age & & \multirow{3}{*}{ Equiaxed } & & $\begin{array}{c}1100\left(23^{\circ} \mathrm{C}, \mathrm{xy}\right) \\
900\left(750^{\circ} \mathrm{C}\right)\end{array}$ & $\begin{array}{c}1250\left(23^{\circ} \mathrm{C}, \mathrm{xy}\right) \\
1050\left(750^{\circ} \mathrm{C}\right)\end{array}$ & & 2 \\
\hline & Laser + STA & & & & $\begin{array}{c}950\left(23^{\circ} \mathrm{C}, \mathrm{xy}\right) 800 \\
\left(750^{\circ} \mathrm{C}\right)\end{array}$ & $\begin{array}{c}1300\left(23^{\circ} \mathrm{C}, \mathrm{xy}\right) \\
800\left(750^{\circ} \mathrm{C}\right)\end{array}$ & & $\begin{array}{c}12\left(23^{\circ} \mathrm{C}, \mathrm{xy}\right) \\
1\left(750^{\circ} \mathrm{C}\right) \\
\end{array}$ \\
\hline & Cast & & & & $\begin{array}{c}650\left(23^{\circ} \mathrm{C}\right) 450 \\
\left(750^{\circ} \mathrm{C}\right)\end{array}$ & $\begin{array}{c}750\left(23^{\circ} \mathrm{C}\right) \\
750\left(750^{\circ} \mathrm{C}\right)\end{array}$ & & $\begin{array}{c}3\left(23^{\circ} \mathrm{C}\right) \\
7\left(750^{\circ} \mathrm{C}\right)\end{array}$ \\
\hline \multirow{3}{*}{ Inconel 713LC [147] } & Laser & \multirow{2}{*}{$1-187.5$} & \multirow{2}{*}{ Columnar/Equiaxed } & & $760-800$ & $933-998$ & & $10-13$ \\
\hline & Laser + HT & & & & 618-818 & $610-911$ & & $0-8$ \\
\hline & Cast & & Equiaxed & & 750 & 850 & & 8.5 \\
\hline \multirow[t]{2}{*}{ Inconel 738LC [148] } & Laser & & Columnar & $\gamma$ & $\begin{array}{c}786\left(23^{\circ} \mathrm{C}, \mathrm{z}\right) 503 \\
\left(850^{\circ} \mathrm{C}, \mathrm{z}\right) \\
933\left(23^{\circ} \mathrm{C}, \mathrm{xy}\right) 610 \\
\left(850^{\circ} \mathrm{C}, \mathrm{xy}\right)\end{array}$ & $\begin{array}{c}1162\left(23^{\circ} \mathrm{C}, \mathrm{z}\right) \\
688\left(850^{\circ} \mathrm{C}, \mathrm{z}\right) \\
1184\left(23^{\circ} \mathrm{C}, \mathrm{xy}\right) \\
716\left(850^{\circ} \mathrm{C}, \mathrm{xy}\right)\end{array}$ & $\begin{array}{c}158\left(23^{\circ} \mathrm{C}, \mathrm{z}\right) \\
110\left(850^{\circ} \mathrm{C}, \mathrm{z}\right) \\
233\left(23^{\circ} \mathrm{C}, \mathrm{xy}\right) \\
157\left(850^{\circ} \mathrm{C},\right. \\
\mathrm{xy}) \\
\end{array}$ & $\begin{array}{l}11.2\left(23^{\circ} \mathrm{C}, \mathrm{z}\right) \\
14.2\left(850^{\circ} \mathrm{C}, \mathrm{z}\right) \\
8.4\left(23^{\circ} \mathrm{C}, \mathrm{xy}\right) \\
8\left(850^{\circ} \mathrm{C}, \mathrm{xy}\right)\end{array}$ \\
\hline & Cast & & & $\gamma+\gamma^{\prime}$ & $\begin{array}{c}765\left(23^{\circ} \mathrm{C}\right) 530 \\
\left(850^{\circ} \mathrm{C}\right)\end{array}$ & $\begin{array}{c}945\left(23^{\circ} \mathrm{C}\right) 710 \\
\left(850^{\circ} \mathrm{C}\right)\end{array}$ & $\begin{array}{r}200\left(23^{\circ} \mathrm{C}\right) \\
144\left(850^{\circ} \mathrm{C}\right)\end{array}$ & $\begin{array}{l}7.5\left(23^{\circ} \mathrm{C}\right) \\
10\left(850^{\circ} \mathrm{C}\right)\end{array}$ \\
\hline \multirow{4}{*}{ SS316L [193,199-201,215] } & $\mathrm{EBM}+\mathrm{HIP}$ & & \multirow{3}{*}{$\begin{array}{l}\text { Hierarchical/Columnar/ } \\
\text { Cellular/Equiaxed }\end{array}$} & \multirow[t]{3}{*}{$\mathrm{FCC}+\mathrm{Cr}, \mathrm{Mo}$} & & & & \\
\hline & \multirow{2}{*}{ Laser } & $18-45$ & & & & $110-580$ & & $1.3-12.2$ \\
\hline & & & & & $450-700$ & & & $22-62$ \\
\hline & Laser + HT & & & Austenite + perlite & & & & \\
\hline 14-7PH [205,206,223,225] & Laser & $91-109$ & Columnar/Dendritic/Cellular & $\begin{array}{l}\text { Austenite }+\mathrm{Nb} \text { carbide } \\
\quad+\text { martensite }\end{array}$ & $600-1180$ & $950-1300$ & & $3-10$ \\
\hline DS 2507SAF [212] & Laser & 127 & Mosaic/Equiaxed & Nitride + ferrite & 1214 & 1321 & & \\
\hline 24CrNiMoY steel & Laser & $140-210$ & & Bainite & $450-800$ & $480-900$ & & $5-8$ \\
\hline \multirow{3}{*}{$18 \mathrm{Ni}-300$ steel $[219,230]$} & Laser & $25-248$ & Columnar/Cellular/Dendritic & $\begin{array}{l}\mathrm{TiO}_{2}+\mathrm{Al}_{2} \mathrm{O}_{3}+ \\
\text { martensite + low } \\
\quad \text { austenite } \\
\end{array}$ & 1214 & & 163 & $1-13$ \\
\hline & Laser + HT & & Columnar & $\begin{array}{c}\text { Austenite }+ \text { martensite } \\
+\mathrm{Ni}_{3} \mathrm{Ti}_{+} \\
\mathrm{Fe}_{2} \mathrm{Mo} / \mathrm{Fe}_{7} \mathrm{Mo}_{6}\end{array}$ & $1550-1950$ & $1650-2020$ & & $1.5-2$ \\
\hline & Wrought & & Equiaxed & & $760-895$ & & 180 & $6-15$ \\
\hline
\end{tabular}


Table 1. Cont.

\begin{tabular}{|c|c|c|c|c|c|c|c|c|}
\hline Alloys & Process Method & $\begin{array}{l}\text { VED } \\
\left(\mathrm{J} / \mathrm{mm}^{3}\right)\end{array}$ & Morphology & Phases & $\sigma_{\mathrm{y}}(\mathrm{MPa})$ & $\sigma_{\text {UTS }}(\mathrm{MPa})$ & $E$ (GPa) & $\varepsilon(\%)$ \\
\hline \multirow{2}{*}{ X3NiCoMoTi 18-9-5 maraging steel [220] } & Laser & & Columnar/Cellular/Equiaxed & $\begin{array}{l}\mathrm{Ni}_{3} \mathrm{Ti}+\text { martensite }+ \\
\text { low austenite }\end{array}$ & 903 & 1050 & & 8 \\
\hline & Cast & & & & 798 & 981 & & 10 \\
\hline Martensitic 420 stainless steel [221] & Laser & 139 & Columnar/Cellular & Martensite-austenite & 600 & 1670 & & 3.5 \\
\hline Al 2024 alloy [263] & EBM & $11-58$ & Equiaxed/Columnar & $\begin{array}{c}\mathrm{AlCuMnFe}+ \\
\mathrm{AlCuMnFeSi}+\text { eutectic } \\
\mathrm{Al}_{2} \mathrm{Cu} / \alpha\end{array}$ & 191 & 314 & & $0.6-7.8$ \\
\hline \multirow{3}{*}{ AlSi10Mg [281,282,303] } & Laser & $14-317$ & Columnar/Equiaxed & $\alpha+$ Al-Si eutectice & $\begin{array}{r}220-230(\mathrm{z}) \\
250-280(\mathrm{xy})\end{array}$ & $340(\mathrm{xy}) 320(\mathrm{z})$ & & $\begin{array}{c}1-5(\mathrm{z}) \\
1.5-8(\mathrm{xy})\end{array}$ \\
\hline & Laser + HT & & Columnar/Equiaxed & $\begin{array}{l}\beta-\mathrm{AlFeSi}+\alpha+\mathrm{Al}-\mathrm{Si} \\
\quad \text { eutectice }\end{array}$ & $\begin{array}{r}139-175(\mathrm{z}) \\
153-180(\mathrm{xy})\end{array}$ & $\begin{array}{c}245-290(\mathrm{z}) \\
269-285(\mathrm{xy})\end{array}$ & & $\begin{array}{c}14-18(\mathrm{z}) \\
18(\mathrm{xy})\end{array}$ \\
\hline & Cast & & & & 150 & 330 & & 3.0 \\
\hline \multirow{2}{*}{ Al-12Si [284] } & Laser & $30-40$ & Columnar/Cellular & $\alpha / \mathrm{Al}-\mathrm{Si}$ & 260 & 380 & & 3.0 \\
\hline & Laser + HT & & & & $100-250$ & $120-370$ & & 2-15 \\
\hline $\mathrm{Al} 4047$ [267] & Laser & $20 \& 39.6$ & Columnar/ Dendritic & $\alpha / \mathrm{Al}+\mathrm{Al}-\mathrm{Si}$ eutectice & $180-220$ & $220-420$ & $57-79$ & $1-4$ \\
\hline Al-Cu-Mg $[270,298]$ & Laser & $166-881$ & Columnar/Cellular & $\begin{array}{c}\alpha-\mathrm{Al}+\mathrm{Cu} \text {-rich } \\
\text { interdendritic eutectic }\end{array}$ & 253 & 393 & & 6.0 \\
\hline \multirow{2}{*}{$\mathrm{Al}-\mathrm{Zn}-\mathrm{Mg}-\mathrm{Cu}[271]$} & Laser & 350 & Columnar & $\eta+\alpha-\mathrm{Al}$ & & & & \\
\hline & Laser + HT & 350 & Columnar & $\alpha-\mathrm{Al}$ & & & & \\
\hline AlSi7Mg0.3 [272] & Laser & $12-385$ & Columnar/Cellular/Dendritic & & 200 & 400 & & $12-17$ \\
\hline AlCu5MnCdVA [274] & Laser & $333-666$ & Columnar & $\alpha-\mathrm{Al}+\mathrm{Al}_{2} \mathrm{Cu}$ & $145-157$ & $310-320$ & & $11.5-14.5$ \\
\hline Al-Mg-Zr [278] & Laser & $77 \& 154$ & Columnar & $\alpha-\mathrm{Al}$ & & & & \\
\hline $\mathrm{Al}-\mathrm{Mg}-\mathrm{Zr} / \mathrm{Sc}[278]$ & Laser & $77 \& 154$ & Equiaxed & $\alpha-\mathrm{Al}+\mathrm{Al} 3 \mathrm{Sc}$ & & & & \\
\hline \multirow{2}{*}{ Al-14.1Mg-0.47Si-0.31Sc-0.17Zr $[279,280]$} & Laser & $27-400$ & \multirow{2}{*}{ Columnar/Equiaxed } & $\begin{array}{c}\alpha-\mathrm{Al}^{+}+\mathrm{Al}_{3}(\mathrm{Sc}, \mathrm{Zr})+ \\
\mathrm{Al}_{12} \mathrm{Mg}_{17} \\
\end{array}$ & 320 & 500 & 103-118 & 16 \\
\hline & Laser + HT & 266 & & $\begin{array}{c}\alpha-\mathrm{Al}+\mathrm{Al}_{3}(\mathrm{Sc}, \mathrm{Zr})+ \\
\mathrm{Mg}_{2} \mathrm{Si}\end{array}$ & 400 & 550 & & 18 \\
\hline Al-8.5Fe-1.3V-1.7Si [288] & Laser & $200 \& 250$ & Cellular/Dendritic & $\begin{array}{c}\alpha-\mathrm{Al}+\mathrm{Al}_{12}(\mathrm{Fe}, \mathrm{V})_{3} \mathrm{Si}+ \\
\theta-\mathrm{Al}_{13} \mathrm{Fe}_{4}\end{array}$ & & & & \\
\hline
\end{tabular}


Table 1. Cont.

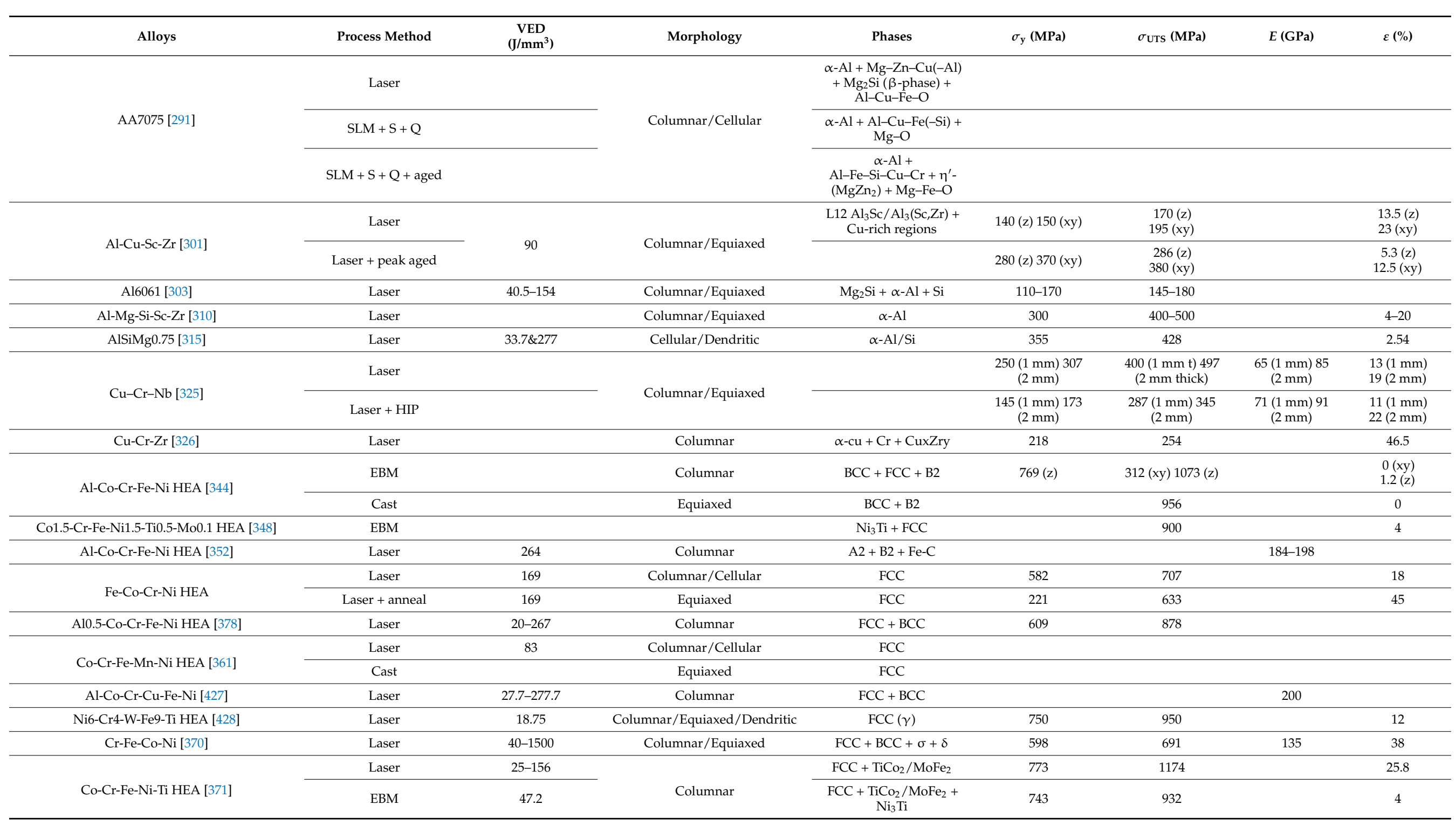


Table 1. Cont.

\begin{tabular}{|c|c|c|c|c|c|c|c|c|}
\hline Alloys & Process Method & $\begin{array}{l}\text { VED } \\
\left(\mathrm{J} / \mathrm{mm}^{3}\right)\end{array}$ & Morphology & Phases & $\sigma_{\mathrm{y}}(\mathrm{MPa})$ & $\sigma_{\text {UTS }}(\mathrm{MPa})$ & $E(\mathrm{GPa})$ & $\varepsilon(\%)$ \\
\hline Co-Cr-Fe-Mn-Ni HEA [383] & Laser & $31-231$ & Columnar/Equiaxed/Cellular & FCC & & & & \\
\hline Fe-Cr-Mo-W-Mn-C-Si-B MG [391] & Laser & $24-42$ & & Amorphous & & & & \\
\hline $\mathrm{Zr}_{55} \mathrm{Cu}_{30} \mathrm{Ni}_{5} \mathrm{Al}_{10} \mathrm{MG}$ & Laser & 33.3 & & $\begin{array}{c}\text { Amorphous + } \\
\text { intermetallic }\end{array}$ & & $1504(\mathrm{C})$ & & 0 \\
\hline $\mathrm{Zr}_{59.3} \mathrm{Cu}_{28.8} \mathrm{Al}_{10.4} \mathrm{Nb}_{1.5} \mathrm{MG}$ [405] & Laser & 27.7 & & $\begin{array}{c}\text { Amorphous + } \\
\text { nanocrystalline }\end{array}$ & & $1368(\mathrm{C})$ & & 0 \\
\hline $\mathrm{Zr}_{52.5} \mathrm{Cu}_{17.9} \mathrm{Ni}_{14.6} \mathrm{Al}_{10} \mathrm{Ti}_{5} \mathrm{MG}$ [410] & Laser & 13.7 & & Amorphous & $1420(\mathrm{C})$ & $1540-1700(\mathrm{C})$ & & 0.5 \\
\hline $\mathrm{Cu}_{50} \mathrm{Zr}_{43} \mathrm{Al}_{7} \mathrm{MG}$ [415] & Laser & $17.4-28.8$ & & $\begin{array}{c}\text { Amorphous }+\mathrm{CuZr}+ \\
\mathrm{Cu}_{10} \mathrm{Zr}_{7}+\mathrm{Al}_{2} \mathrm{Zr}\end{array}$ & $1044(\mathrm{C})$ & & 129 & 0 \\
\hline
\end{tabular}


Table 2. Summary of corrosion properties of additively manufactured alloys ( $i_{\text {corr }}$ : corrosion current density; $i_{\mathrm{p}}$ : passive current density; $E_{\mathrm{corr}}$ : corrosion potential; $E_{\mathrm{pit}}$ : pitting potential).

\begin{tabular}{|c|c|c|c|c|c|c|}
\hline Alloys & $\begin{array}{l}\text { Process } \\
\text { Method }\end{array}$ & $i_{\text {corr }}\left(\mu \mathrm{A} / \mathrm{cm}^{2}\right)$ & $i_{\mathrm{p}}\left(\mu \mathrm{A} / \mathrm{cm}^{2}\right)$ & $\begin{array}{l}E_{\text {corr }}(\mathrm{mV} \\
\text { vs. Ref) }\end{array}$ & $\begin{array}{l}E_{\text {pit }}(\mathrm{mV} \\
\text { vs. Ref) }\end{array}$ & Medium \\
\hline \multirow{13}{*}{$\begin{array}{c}\text { Ti-6Al-4V } \\
{[67,92,94,96,98,99,101]}\end{array}$} & \multirow{3}{*}{ EBM } & 0.199 & 1.65 & -246 & & $\left(\mathrm{~N}_{2}+10 \% \mathrm{CO}_{2}\right)$ \\
\hline & & $\begin{array}{c}0.14\left(0^{\circ}\right) 0.53\left(45^{\circ}\right) \\
0.26\left(55^{\circ}\right) 0.20 \\
\left(90^{\circ}\right)\end{array}$ & $\begin{array}{c}7.41\left(0^{\circ}\right) 26.79 \\
\left(45^{\circ}\right) 12.94\left(55^{\circ}\right) \\
15.67\left(90^{\circ}\right)\end{array}$ & $\begin{array}{l}-73\left(0^{\circ}\right) \\
-109\left(45^{\circ}\right) \\
-93\left(55^{\circ}\right) \\
-143\left(90^{\circ}\right)\end{array}$ & & $1 \mathrm{M} \mathrm{HCl}$ \\
\hline & & 0.007 & 0.73 & -0.28 & & $\begin{array}{c}\text { Phosphate } \\
\text { buffered saline }\end{array}$ \\
\hline & \multirow{4}{*}{ Laser } & 0.023 & 0.87 & -239 & & $\left(\mathrm{~N}_{2}+10 \% \mathrm{CO}_{2}\right)$ \\
\hline & & 8.5 & 4000 & -450 & & 3.5 wt. $\% \mathrm{NaCl}$ \\
\hline & & & $2.83(\mathrm{z}) 2.5(\mathrm{xy})$ & -200 & & $1 \mathrm{M} \mathrm{HCl}$ \\
\hline & & & 0.7 & -350 & & $\begin{array}{l}\text { Ringer's } \\
\text { simulated body } \\
\text { solution. }\end{array}$ \\
\hline & Laser + HT & $0.15-9.5$ & $80-1000$ & -550 to -420 & & 3.5 wt. $\% \mathrm{NaCl}$ \\
\hline & WAAM & 0.45 & 500 & -380 & & 3.5 wt. $\% \mathrm{NaCl}$ \\
\hline & Cast & 0.199 & 1.14 & -243 & & $\left(\mathrm{~N}_{2}+10 \% \mathrm{CO}_{2}\right)$ \\
\hline & \multirow[b]{2}{*}{ Wrought } & 0.049 & 0.837 & -159 & & $\left(\mathrm{~N}_{2}+10 \% \mathrm{CO}_{2}\right)$ \\
\hline & & 0.012 & 0.69 & -290 & & $\begin{array}{l}\text { phosphate- } \\
\text { buffered } \\
\text { saline }\end{array}$ \\
\hline & $\begin{array}{l}\text { Forged }+ \text { roll }+ \\
\text { anneal }\end{array}$ & 0.35 & 200 & -480 & & 3.5 wt. $\% \mathrm{NaCl}$ \\
\hline \multirow{6}{*}{ Alloy 625 [185] } & \multirow[b]{2}{*}{ Laser } & 0.59 & 0.9 & -340 & & $0.6 \mathrm{M} \mathrm{NaCl}$ \\
\hline & & 0.79 & 1.14 & -100 & & $0.5 \mathrm{M} \mathrm{H}_{2} \mathrm{SO}_{4}$ \\
\hline & \multirow{2}{*}{ Laser + HT } & 0.55 & 0.9 & -397 & & $0.6 \mathrm{M} \mathrm{NaCl}$ \\
\hline & & 0.99 & 1.26 & -122 & & $0.5 \mathrm{M} \mathrm{H}_{2} \mathrm{SO}_{4}$ \\
\hline & \multirow[b]{2}{*}{ Cast } & 0.58 & 0.5 & -272 & & $0.6 \mathrm{M} \mathrm{NaCl}$ \\
\hline & & 0.51 & 1.18 & -76 & & $0.5 \mathrm{M} \mathrm{H}_{2} \mathrm{SO}_{4}$ \\
\hline \multirow{4}{*}{ SS316L [248,249,251] } & \multirow{2}{*}{ Laser } & $0.01-0.05$ & & -80 & $650-750$ & $0.6 \mathrm{M} \mathrm{NaCl}$ \\
\hline & & $0.3-0.9$ & & -130 to -200 & $300-750$ & $0.1 \mathrm{M} \mathrm{NaCl}$ \\
\hline & Laser + HT & $0.003-0.05$ & & -30 to -80 & $350-540$ & $0.6 \mathrm{M} \mathrm{NaCl}$ \\
\hline & Wrought & 0.02 & & -150 & 230 & $0.6 \mathrm{M} \mathrm{NaCl}$ \\
\hline \multirow{2}{*}{ 17-4 PH steel [429] } & Laser + HT & 0.2 & & -50 & & $0.6 \mathrm{M} \mathrm{NaCl}$ \\
\hline & Wrough + HT & 0.02 & & 50 & & $0.6 \mathrm{M} \mathrm{NaCl}$ \\
\hline \multirow{2}{*}{$\begin{array}{l}\text { Al-14.1Mg-0.47Si-0.31Sc- } \\
0.17 \mathrm{Zr}[279]\end{array}$} & Laser & 0.15 & & -920 & -0.75 & 3.5 wt. $\% \mathrm{NaCl}$ \\
\hline & Laser + HT & 2.5 & & -1200 & -880 & 3.5 wt. $\% \mathrm{NaCl}$ \\
\hline \multirow{3}{*}{ AA7075 [291] } & Laser & 900 & & -900 & & $0.1 \mathrm{M} \mathrm{NaCl}$ \\
\hline & Laser $+\mathrm{S}+\mathrm{Q}$ & 8000 & & -1400 & & $0.1 \mathrm{M} \mathrm{NaCl}$ \\
\hline & $\begin{array}{l}\mathrm{SLM}+\mathrm{S}+\mathrm{Q}+ \\
\text { aged }\end{array}$ & 1000 & & -1.2 & & $0.1 \mathrm{M} \mathrm{NaCl}$ \\
\hline Al-Mg-Zr-Sc [317] & Laser & $57.1(x y) 209(z)$ & & $\begin{array}{l}-1400(\mathrm{xy}) \\
-1500(\mathrm{z})\end{array}$ & $\begin{array}{l}-590(\mathrm{xy}) \\
-0630(\mathrm{z})\end{array}$ & 3.5 wt. $\% \mathrm{NaCl}$ \\
\hline \multirow{3}{*}{ AlCoCrFeNi HEA $[344,352]$} & EBM & 0.02 & 1.45 & -355 & 112 & $\begin{array}{l}\text { Artificial } \\
\text { seawater }\end{array}$ \\
\hline & Laser & $0.00003-0.0001$ & & -670 to -560 & & 3.5 wt. $\% \mathrm{NaCl}$ \\
\hline & Cast & 0.02 & 1.48 & -270 & 178 & \\
\hline
\end{tabular}


Table 2. Cont.

\begin{tabular}{|c|c|c|c|c|c|c|}
\hline Alloys & $\begin{array}{l}\text { Process } \\
\text { Method }\end{array}$ & $i_{\text {corr }}\left(\mu \mathrm{A} / \mathrm{cm}^{2}\right)$ & $i_{\mathrm{p}}\left(\mu \mathrm{A} / \mathrm{cm}^{2}\right)$ & $\begin{array}{l}E_{\text {corr }}(\mathrm{mV} \\
\text { vs. Ref })\end{array}$ & $\begin{array}{l}E_{\text {pit }}(\mathrm{mV} \\
\text { vs. Ref) }\end{array}$ & Medium \\
\hline \multirow{2}{*}{$\begin{array}{c}\text { CoCrFeMnNi HEA } \\
{[347,383]}\end{array}$} & Laser & $0.047-0.09$ & & -265 to -189 & 197 & 3.5 wt. $\% \mathrm{NaCl}$ \\
\hline & Cast & 1.1 & & -457 & & 3.5 wt. $\% \mathrm{NaCl}$ \\
\hline $\begin{array}{c}\text { AlCoFeNiTiV }{ }_{0.9} S_{0.1} \text { HEA } \\
{[384]}\end{array}$ & Laser & 0.005 & & -630 & & 3.5 wt. $\% \mathrm{NaCl}$ \\
\hline $\begin{array}{c}\mathrm{AlCoFeNiV}{ }_{0.9} \mathrm{Sm}_{0.1} \mathrm{HEA} \\
{[384]}\end{array}$ & Laser & 0.001 & & -930 & & 3.5 wt. $\% \mathrm{NaCl}$ \\
\hline$\underset{[410]}{\mathrm{Zr}_{52.5} \mathrm{Cu} 1_{7.9} \mathrm{Ni1}_{4.6} \mathrm{Al}_{10} \mathrm{Ti}_{5}}$ & Laser & 0.001 & & -350 & 0.1 & $\begin{array}{c}\text { 0.01 } \mathrm{M} \mathrm{Na}_{2} \mathrm{SO}_{4}+ \\
0.1 \mathrm{M} \mathrm{NaCl}\end{array}$ \\
\hline
\end{tabular}

\section{Concluding Remarks}

This study summarized the state-of-the art in the fabrication of a variety of materials using laser or electron beam powder bed fusion additive manufacturing (PBF-AM) including Ti, Ni, steel, Cu, Al, HEAs, and BMGs. Their microstructure, part quality, mechanical properties, and corrosion behavior were reviewed as a function of processing parameters and post-processing conditions and compared with traditionally fabricated counterparts.It was found that parts/alloys fabricated using PBF-AM experience a complex thermal history, involving directional heat extraction, and repeated melting and rapid solidification, which make the analysis of their microstructure and properties challenging. Typically, a higher solidification rate in the AM process reduces the grain sizes of alloys, and the mechanical properties of AM-built materials are comparable to conventionally fabricated counterparts. Anisotropy in properties was found for almost all PBF-AM fabricated components, in which plane parallel to building direction (Z-direction) was the weakest compared to the plane perpendicular to the building direction $(X Y)$. In addition, defects such as porosity and cracks were found in most AM-built parts, which has detrimental effect on their mechanical properties; optimization of processing parameters as well as post-processing were necessary to reduce those defects. In sum, despite significant attempts to provide a fundamental understanding of AM technique, structure, and properties of built samples, continued research is necessary in order to obtain knowledge of how to fabricate defect-free parts with superior properties at a minimized cost using PBF-AM.

Funding: This research received no external funding.

Institutional Review Board Statement: Not applicable.

Informed Consent Statement: Not applicable.

Conflicts of Interest: The authors declare no conflict of interest.

\section{References}

1. Harun, W.; Kamariah, M.; Muhamad, N.; Ghani, S.A.C.; Ahmad, F.; Mohamed, Z. A review of powder additive manufacturing processes for metallic biomaterials. Powder Technol. 2018, 327, 128-151. [CrossRef]

2. Kruth, J.-P.; Levy, G.; Klocke, F.; Childs, T. Consolidation phenomena in laser and powder-bed based layered manufacturing. CIRP Ann. 2007, 56, 730-759. [CrossRef]

3. Ansari, M.; Jabari, E.; Toyserkani, E. Opportunities and challenges in additive manufacturing of functionally graded metallic materials via powder-fed laser directed energy deposition: A review. J. Mater. Process. Technol. 2021, 294, 117117. [CrossRef]

4. Emmelmann, C.; Herzog, D.; Kranz, J. Design for Laser Additive Manufacturing; Elsevier BV: Amsterdam, The Netherlands, 2017; pp. 259-279.

5. EOS. Laser sintering system EOSINT M 280 for the production of tooling inserts, prototype parts and end products directly in metal. In The Technology: Laser Sintering-The Key to e-Manufacturing; EOS GmbH Electro Optical Systems Corporate Headquarters: Krailling, Germany; Munich, Germany, 2017.

6. Multibeam, E.B.M.; Process, S.W.; Hot, N.C. Arcam Q10 Datasheet; Arcam AB: Mölnlycke, Sweden, 1850.

7. Shen, N.; Chou, K. Numerical Thermal Analysis in Electron Beam Additive. In Proceedings of the 23rd Solid Freeform Fabrication Symposium, Austin, TX, USA, 6-8 August 2012; pp. 774-784. 
8. Shen, N.; Chou, K. Thermal Modeling of Electron Beam Additive Manufacturing Process: Powder Sintering Effects. In Proceedings of the ASME 2012 International Manufacturing Science and Engineering Conference, Notre Dame, IN, USA, 4-8 June 2012; pp. 287-295. [CrossRef]

9. Roberts, I.; Wang, C.; Esterlein, R.; Stanford, M.; Mynors, D. A three-dimensional finite element analysis of the temperature field during laser melting of metal powders in additive layer manufacturing. Int. J. Mach. Tools Manuf. 2009, 49, 916-923. [CrossRef]

10. Arce, A.N. Thermal Modeling and Simulation of Electron Beam Melting for Rapid Prototyping on Ti6Al4V Alloys; North Carolina State University: Raleigh, NC, USA, 2012.

11. Arcam, A.B. Arcam Q20 Technical Data. 2015. Available online: www.arcam.com/wp-content/uploads/Arcam-Q20-final.pdf (accessed on 25 August 2021).

12. Tamayo, J.A.; Riascos, M.; Vargas, C.A.; Baena, L.M. Additive manufacturing of Ti6Al4V alloy via electron beam melting for the development of implants for the biomedical industry. Heliyon 2021, 7, e06892. [CrossRef]

13. Jeong, S.-J.; Lee, H.-J.; Lee, B.-S. Effect of electron beam continuity on microstructures and mechanical properties of titanium lattice structures produced with electron beam additive manufacturing. Mater. Des. 2021, 207, 109822. [CrossRef]

14. Balachandramurthi, A.R.; Moverare, J.; Hansson, T.; Pederson, R. Anisotropic fatigue properties of Alloy 718 manufactured by Electron Beam Powder Bed Fusion. Int. J. Fatigue 2020, 141, 105898. [CrossRef]

15. Mian, J.; Razmi, J.; Ladani, L. Defect analysis and fatigue strength prediction of as-built Ti6Al4V parts, produced using electron beam melting (EBM) AM technology. Materialia 2021, 16, 101041. [CrossRef]

16. Mian, J.; Razmi, J.; Ladani, L. Mechanical Behavior of Electron Beam Powder Bed Fusion Additively Manufactured Ti6Al4V Parts at Elevated Temperatures. J. Manuf. Sci. Eng. 2021, 143, 1-24. [CrossRef]

17. Heinl, P.; Körner, C.; Singer, R.F. Selective Electron Beam Melting of Cellular Titanium: Mechanical Properties. Adv. Eng. Mater. 2008, 10, 882-888. [CrossRef]

18. Youn, S.-J.; Kim, Y.-K.; Kim, S.-W.; Lee, K.-A. Elevated temperature compressive deformation behaviors of $\gamma$-TiAl-based Ti-48Al$2 \mathrm{Cr}-2 \mathrm{Nb}$ alloy additively manufactured by electron beam melting. Intermetallics 2020, 124, 106859. [CrossRef]

19. Al-Bermani, S.S.; Blackmore, M.L.; Zhang, W.; Todd, I. The Origin of Microstructural Diversity, Texture, and Mechanical Properties in Electron Beam Melted Ti-6Al-4V. Metall. Mater. Trans. A 2010, 41, 3422-3434. [CrossRef]

20. Seifi, M.; Salem, A.A.; Satko, D.P.; Ackelid, U.; Semiatin, S.L.; Lewandowski, J.J. Effects of HIP on microstructural heterogeneity, defect distribution and mechanical properties of additively manufactured EBM Ti-48Al-2Cr-2Nb. J. Alloys Compd. 2017, 729, 1118-1135. [CrossRef]

21. Todai, M.; Nakano, T.; Liu, T.; Yasuda, H.; Hagihara, K.; Cho, K.; Ueda, M.; Takeyama, M. Effect of building direction on the microstructure and tensile properties of Ti-48Al-2Cr-2Nb alloy additively manufactured by electron beam melting. Addit. Manuf. 2017, 13, 61-70. [CrossRef]

22. Murr, L.; Martinez, E.; Pan, X.; Gaytan, S.; Castro, J.; Terrazas, C.; Medina, F.; Wicker, R.; Abbott, D. Microstructures of Rene 142 nickel-based superalloy fabricated by electron beam melting. Acta Mater. 2013, 61, 4289-4296. [CrossRef]

23. Ramsperger, M.; Singer, R.F.; Körner, C. Microstructure of the Nickel-Base Superalloy CMSX-4 Fabricated by Selective Electron Beam Melting. Metall. Mater. Trans. A 2016, 47, 1469-1480. [CrossRef]

24. Chandra, S.; Tan, X.; Narayan, R.L.; Wang, C.; Tor, S.B.; Seet, G. A generalised hot cracking criterion for nickel-based superalloys additively manufactured by electron beam melting. Addit. Manuf. 2021, 37, 101633. [CrossRef]

25. Yu, P.; Qian, M.; Tomus, D.; Brice, C.; Schaffer, G.B.; Muddle, B.C. Electron Beam Processing of Aluminium Alloys. Mater. Sci. Forum 2009, 618-619, 621-626. [CrossRef]

26. Cormier, D.; Harrysson, O.; West, H. Characterization of $\mathrm{H} 13$ steel produced via electron beam melting. Rapid Prototyp. J. 2004, 10, 35-41. [CrossRef]

27. Gaytan, S.; Murr, L.; Martinez, E.; Martinez, J.; Machado, B.; Ramirez, D.; Medina, F.J.; Collins, S.D.; Wicker, R. Comparison of Microstructures and Mechanical Properties for Solid and Mesh Cobalt-Base Alloy Prototypes Fabricated by Electron Beam Melting. Metall. Mater. Trans. A 2010, 41, 3216-3227. [CrossRef]

28. Ramirez, D.; Murr, L.; Martinez, E.; Hernandez, D.; Martinez, J.; Machado, B.; Medina, F.; Frigola, P.; Wicker, R. Novel precipitateMicrostructural architecture developed in the fabrication of solid copper components by additive manufacturing using electron beam melting. Acta Mater. 2011, 59, 4088-4099. [CrossRef]

29. Zykova, A.; Nikonov, S.; Utyaganova, V.; Shamarin, N.; Ivanov, A.; Chumaevskii, A. Process Control Features of Electron-Beam Additive Manufacturing of Austenitic Stainless Steel. Procedia Struct. Integr. 2020, 30, 216-223. [CrossRef]

30. Gong, X.; Anderson, T.; Chou, K. Review on powder-based electron beam additive manufacturing technology. Manuf. Rev. 2014, 1, 2. [CrossRef]

31. Sochalski-Kolbus, L.M.; Payzant, E.; Cornwell, P.A.; Watkins, T.; Babu, S.; Dehoff, R.; Lorenz, M.; Ovchinnikova, O.; Duty, C. Comparison of Residual Stresses in Inconel 718 Simple Parts Made by Electron Beam Melting and Direct Laser Metal Sintering. Metall. Mater. Trans. A 2015, 46, 1419-1432. [CrossRef]

32. Elahinia, M.; Moghaddam, N.S.; Andani, M.T.; Amerinatanzi, A.; Bimber, B.A.; Hamilton, R.F. Fabrication of NiTi through additive manufacturing: A review. Prog. Mater. Sci. 2016, 83, 630-663. [CrossRef]

33. Hrabe, N.; Gnäupel-Herold, T.; Quinn, T. Fatigue properties of a titanium alloy (Ti-6Al-4V) fabricated via electron beam melting (EBM): Effects of internal defects and residual stress. Int. J. Fatigue 2017, 94, 202-210. [CrossRef] 
34. Sing, S.L.; An, J.; Yeong, W.Y.; Wiria, F.E. Laser and electron-beam powder-bed additive manufacturing of metallic implants: A review on processes, materials and designs. J. Orthop. Res. 2016, 34, 369-385. [CrossRef] [PubMed]

35. Tofail, S.A.; Koumoulos, E.P.; Bandyopadhyay, A.; Bose, S.; O’Donoghue, L.; Charitidis, C. Additive manufacturing: Scientific and technological challenges, market uptake and opportunities. Mater. Today 2018, 21, 22-37. [CrossRef]

36. Liu, G.; Zhang, X.; Chen, X.; He, Y.; Cheng, L.; Huo, M.; Yin, J.; Hao, F.; Chen, S.; Wang, P.; et al. Additive manufacturing of structural materials. Mater. Sci. Eng. R Rep. 2021, 145, 100596. [CrossRef]

37. Seifi, M.; Gorelik, M.; Waller, J.; Hrabe, N.; Shamsaei, N.; Daniewicz, S.; Lewandowski, J.J. Progress Towards Metal Additive Manufacturing Standardization to Support Qualification and Certification. JOM 2017, 69, 439-455. [CrossRef]

38. Sateesh, N.; Kumar, G.M.; Prasad, K.; Srinivasa, C.K.; Vinod, A. Microstructure and Mechanical Characterization of Laser Sintered Inconel-625 Superalloy. Procedia Mater. Sci. 2014, 5, 772-779. [CrossRef]

39. Jia, Q.; Gu, D. Selective laser melting additive manufacturing of Inconel 718 superalloy parts: Densification, microstructure and properties. J. Alloys Compd. 2014, 585, 713-721. [CrossRef]

40. Jia, Q.; Gu, D. Selective laser melting additive manufactured Inconel 718 superalloy parts: High-temperature oxidation property and its mechanisms. Opt. Laser Technol. 2014, 62, 161-171. [CrossRef]

41. Muñiz-Lerma, J.A.; Nommeots-Nomm, A.; Waters, K.E.; Brochu, M. A Comprehensive Approach to Powder Feedstock Characterization for Powder Bed Fusion Additive Manufacturing: A Case Study on AlSi7Mg. Materials 2018, 11, 2386. [CrossRef]

42. Slotwinski, J.A.; Garboczi, E.J.; Stutzman, P.E.; Ferraris, C.F.; Watson, S.S.; Peltz, M.A. Characterization of Metal Powders Used for Additive Manufacturing. J. Res. Natl. Inst. Stand. Technol. 2014, 119, 460-493. [CrossRef]

43. Harun, W.; Manam, N.; Kamariah, M.; Sharif, S.; Zulkifly, A.H.; Ahmad, I.; Miura, H. A review of powdered additive manufacturing techniques for Ti-6al-4v biomedical applications. Powder Technol. 2018, 331, 74-97. [CrossRef]

44. Lütjering, G.; Williams, J.C. Titanium (Engineering Materials and Processes); Springer: Berlin/Heidelberg, Germany, 2007.

45. Pederson, R. Microstructure and Phase Transformation of Ti-6Al-4V. Licentiate Thesis, Lulea University, Luleå, Sweden, 2002.

46. Sieniawski, J.; Ziaja, W.; Kubiak, K.; Motyka, K.K.A.M. Microstructure and Mechanical Properties of High Strength Two-Phase Titanium Alloys. In Titanium Alloys-Advances in Properties Control; BoD—Books on Demand: Norderstedt, Germany, 2013. [CrossRef]

47. Zhang, M.; Zhang, J.; McDowell, D. Microstructure-based crystal plasticity modeling of cyclic deformation of Ti-6Al-4V. Int. J. Plast. 2007, 23, 1328-1348. [CrossRef]

48. Follansbee, P.S.; Gray, G.T. An analysis of the low temperature, low and high strain-rate deformation of Ti-6Al-4V. Metall. Mater. Trans. A 1989, 20, 863-874. [CrossRef]

49. Facchini, L.; Magalini, E.; Robotti, P.; Molinari, A. Microstructure and mechanical properties of Ti-6Al-4V produced by electron beam melting of pre-alloyed powders. Rapid Prototyp. J. 2009, 15, 171-178. [CrossRef]

50. Antonysamy, A.; Meyer, J.; Prangnell, P. Effect of build geometry on the $\beta$-grain structure and texture in additive manufacture of Ti6Al4V by selective electron beam melting. Mater. Charact. 2013, 84, 153-168. [CrossRef]

51. Cormier, D.; West, H.; Harrysson, O.; Knowlson, K. Characterization of Thin Walled Ti-6Al-4V Components Produced via Electron Beam Melting. In Solid Freeform Fabrication Symposium; University of Texas at Austin: Austin, TX, USA, 2004 ; pp. 440-447. Available online: http:/ / sffsymposium.engr.utexas.edu/Manuscripts/2004/2004-44-Cormier.pdf (accessed on 25 August 2021).

52. Ladani, L. Local and Global Mechanical Behavior and Microstructure of Ti6Al4V Parts Built Using Electron Beam Melting Technology. Metall. Mater. Trans. A 2015, 46, 3835-3841. [CrossRef]

53. Safdar, A. A Study on Electron Beam Melted Ti-6Al-4V; Division of Solid Mechanics Department of Construction Sciences, Lund University: Lund, Sweden, 2012.

54. Safdar, A.; Wei, L.-Y.; Snis, A.; Lai, Z. Evaluation of microstructural development in electron beam melted Ti-6Al-4V. Mater. Charact. 2012, 65, 8-15. [CrossRef]

55. Safdar, A.; He, H.; Wei, L.; Snis, A.; de Paz, L.C. Effect of process parameters settings and thickness on surface roughness of EBM produced Ti-6Al-4V. Rapid Prototyp. J. 2012, 18, 401-408. [CrossRef]

56. Safdar, A. Microstructures and Surface Roughness of EBM Produced Ti-6Al-4V; Lund University: Lund, Sweden, 2010.

57. Ladani, L.; Razmi, J.; Choudhury, S.F. Mechanical Anisotropy and Strain Rate Dependency Behavior of Ti6Al4V Produced Using E-Beam Additive Fabrication. J. Eng. Mater. Technol. 2014, 136, 031006. [CrossRef]

58. Murr, L.; Esquivel, E.; Quinones, S.; Gaytan, S.; Lopez, M.; Martinez, E.; Medina, F.; Hernandez, D.; Martinez, J.; Stafford, S.; et al. Microstructures and mechanical properties of electron beam-rapid manufactured Ti-6Al-4V biomedical prototypes compared to wrought Ti-6Al-4V. Mater. Charact. 2009, 60, 96-105. [CrossRef]

59. Gaytan, S.M.; Murr, L.; Medina, F.; Martinez, E.; Lopez, M.I.; Wicker, R.B. Advanced metal powder based manufacturing of complex components by electron beam melting. Mater. Technol. 2009, 24, 180-190. [CrossRef]

60. Li, D.; Huang, H.; Chen, C.; Liu, S.; Liu, X.; Zhang, X.; Zhou, K. Additive manufacturing of high strength near $\beta$ titanium alloy Ti-55511 by engineering nanoscale secondary $\alpha$ laths via in-situ heat treatment. Mater. Sci. Eng. A 2021, 814, 141245. [CrossRef]

61. Cheng, X.; Li, S.; Murr, L.; Zhang, Z.; Hao, Y.; Yang, R.; Medina, F.; Wicker, R. Compression deformation behavior of Ti-6Al-4V alloy with cellular structures fabricated by electron beam melting. J. Mech. Behav. Biomed. Mater. 2012, 16, 153-162. [CrossRef]

62. Li, S.; Xu, Q.; Wang, Z.; Hou, W.; Hao, Y.; Yang, R.; Murr, L. Influence of cell shape on mechanical properties of Ti-6Al-4V meshes fabricated by electron beam melting method. Acta Biomater. 2014, 10, 4537-4547. [CrossRef] [PubMed] 
63. Murr, L.; Gaytan, S.; Ceylan, A.; Martinez, E.; Martinez, J.; Hernandez, D.; Machado, B.; Ramirez, D.; Medina, F.; Collins, S. Characterization of titanium aluminide alloy components fabricated by additive manufacturing using electron beam melting. Acta Mater. 2010, 58, 1887-1894. [CrossRef]

64. Li, N.; Huang, S.; Zhang, G.; Qin, R.; Liu, W.; Xiong, H.; Shi, G.; Blackburn, J. Progress in additive manufacturing on new materials: A review. J. Mater. Sci. Technol. 2019, 35, 242-269. [CrossRef]

65. Murr, L.E.; Gaytan, S.M.; Ramirez, D.A.; Martinez, E.; Hernandez, J.; Amato, K.N.; Shindo, P.W.; Medina, F.R.; Wicker, R.B. Metal Fabrication by Additive Manufacturing Using Laser and Electron Beam Melting Technologies. J. Mater. Sci. Technol. 2012, 28, 1-14. [CrossRef]

66. Hernandez, J.; Li, S.; Martinez, E.; Murr, L.; Pan, X.; Amato, K.; Cheng, X.; Yang, F.; Terrazas, C.; Gaytan, S.; et al. Microstructures and Hardness Properties for $\beta$-Phase Ti-24Nb-4Zr-7.9Sn Alloy Fabricated by Electron Beam Melting. J. Mater. Sci. Technol. 2013, 29, 1011-1017. [CrossRef]

67. Koike, M.; Greer, P.; Owen, K.; Lilly, G.; Murr, L.E.; Gaytan, S.M.; Martinez, E.; Okabe, T.H. Evaluation of Titanium Alloys Fabricated Using Rapid Prototyping Technologies-Electron Beam Melting and Laser Beam Melting. Materials 2011, 4, 1776-1792. [CrossRef] [PubMed]

68. Guo, C.; Ge, W.; Lin, F. Effects of scanning parameters on material deposition during Electron Beam Selective Melting of Ti-6Al-4V powder. J. Mater. Process. Technol. 2015, 217, 148-157. [CrossRef]

69. Juechter, V.; Scharowsky, T.; Singer, R.; Körner, C. Processing window and evaporation phenomena for Ti-6Al-4V produced by selective electron beam melting. Acta Mater. 2014, 76, 252-258. [CrossRef]

70. Ge, W.; Guo, C.; Lin, F. Effect of Process Parameters on Microstructure of TiAl Alloy Produced by Electron Beam Selective Melting. Procedia Eng. 2014, 81, 1192-1197. [CrossRef]

71. Schwerdtfeger, J.; Körner, C. Selective electron beam melting of Ti-48Al-2Nb-2Cr: Microstructure and aluminium loss. Intermetallics 2014, 49, 29-35. [CrossRef]

72. Lin, Y.; Wang, L.-H.; Wu, Q.; Xiao, Y.-W.; Cheng, H.; Zhang, X.-Y. Effects of solution temperature and cooling rate on $\alpha$ phases and mechanical properties of a forged Ti-55511 alloy. Mater. Res. Express 2019, 6, 1165h2. [CrossRef]

73. Balla, V.; Soderlind, J.; Bose, S.; Bandyopadhyay, A. Microstructure, mechanical and wear properties of laser surface melted Ti6Al4V alloy. J. Mech. Behav. Biomed. Mater. 2014, 32, 335-344. [CrossRef] [PubMed]

74. Wauthle, R.; Vrancken, B.; Beynaerts, B.; Jorissen, K.; Schrooten, J.; Kruth, J.-P.; Van Humbeeck, J. Effects of build orientation and heat treatment on the microstructure and mechanical properties of selective laser melted Ti6Al4V lattice structures. Addit. Manuf. 2015, 5, 77-84. [CrossRef]

75. Vrancken, B.; Thijs, L.; Kruth, J.-P.; Van Humbeeck, J. Heat treatment of Ti6Al4V produced by Selective Laser Melting: Microstructure and mechanical properties. J. Alloys Compd. 2012, 541, 177-185. [CrossRef]

76. Sun, J.; Yang, Y.; Wang, D. Parametric optimization of selective laser melting for forming Ti6Al4V samples by Taguchi method. Opt. Laser Technol. 2013, 49, 118-124. [CrossRef]

77. Yadroitsev, I.; Krakhmalev, P.; Yadroitsava, I. Selective laser melting of Ti6Al4V alloy for biomedical applications: Temperature monitoring and microstructural evolution. J. Alloys Compd. 2014, 583, 404-409. [CrossRef]

78. Song, B.; Dong, S.; Zhang, B.; Liao, H.; Coddet, C. Effects of processing parameters on microstructure and mechanical property of selective laser melted Ti6Al4V. Mater. Des. 2012, 35, 120-125. [CrossRef]

79. Sallica-Leva, E.; Jardini, A.; Fogagnolo, J.B. Microstructure and mechanical behavior of porous Ti-6Al-4V parts obtained by selective laser melting. J. Mech. Behav. Biomed. Mater. 2013, 26, 98-108. [CrossRef] [PubMed]

80. Gu, D.; Meiners, W.; Wissenbach, K.; Poprawe, R. Laser additive manufacturing of metallic components: Materials, processes and mechanisms. Int. Mater. Rev. 2012, 57, 133-164. [CrossRef]

81. Carrozza, A.; Aversa, A.; Fino, P.; Lombardi, M. A study on the microstructure and mechanical properties of the Ti-6Al-2Sn-4Zr6Mo alloy produced via Laser Powder Bed Fusion. J. Alloys Compd. 2021, 870, 159329. [CrossRef]

82. Thijs, L.; Verhaeghe, F.; Craeghs, T.; Van Humbeeck, J.; Kruth, J.-P. A study of the microstructural evolution during selective laser melting of Ti-6Al-4V. Acta Mater. 2010, 58, 3303-3312. [CrossRef]

83. Qiu, C.; Adkins, N.J.; Attallah, M. Microstructure and tensile properties of selectively laser-melted and of HIPed laser-melted Ti-6Al-4V. Mater. Sci. Eng. A 2013, 578, 230-239. [CrossRef]

84. Leuders, S.; Thöne, M.; Riemer, A.; Niendorf, T.; Tröster, T.; Richard, H.; Maier, H. On the mechanical behaviour of titanium alloy TiAl6V4 manufactured by selective laser melting: Fatigue resistance and crack growth performance. Int. J. Fatigue 2013, 48, 300-307. [CrossRef]

85. Schwab, H.; Bönisch, M.; Giebeler, L.; Gustmann, T.; Eckert, J.; Kühn, U. Processing of Ti-5553 with improved mechanical properties via an in-situ heat treatment combining selective laser melting and substrate plate heating. Mater. Des. 2017, 130, 83-89. [CrossRef]

86. Polozov, I.; Sufiiarov, V.; Kantyukov, A.; Razumov, N.; Goncharov, I.; Makhmutov, T.; Silin, A.; Kim, A.; Starikov, K.; Shamshurin, A.; et al. Microstructure, densification, and mechanical properties of titanium intermetallic alloy manufactured by laser powder bed fusion additive manufacturing with high-temperature preheating using gas atomized and mechanically alloyed plasma spheroidized powders. Addit. Manuf. 2020, 34, 101374. [CrossRef] 
87. Hrabe, N.; Quinn, T. Effects of processing on microstructure and mechanical properties of a titanium alloy (Ti-6Al-4V) fabricated using electron beam melting (EBM), Part 1: Distance from build plate and part size. Mater. Sci. Eng. A 2013, 573, $264-270$. [CrossRef]

88. Hrabe, N.; Quinn, T. Effects of processing on microstructure and mechanical properties of a titanium alloy (Ti-6Al-4V) fabricated using electron beam melting (EBM), Part 2: Energy input, orientation, and location. Mater. Sci. Eng. A 2013, 573, $271-277$. [CrossRef]

89. Rafi, H.K.; Karthik, N.V.; Gong, H.; Starr, T.L.; Stucker, B.E. Microstructures and Mechanical Properties of Ti6Al4V Parts Fabricated by Selective Laser Melting and Electron Beam Melting. J. Mater. Eng. Perform. 2013, 22, 3872-3883. [CrossRef]

90. Cain, V.; Thijs, L.; Van Humbeeck, J.; Van Hooreweder, B.; Knutsen, R. Crack propagation and fracture toughness of Ti6Al4V alloy produced by selective laser melting. Addit. Manuf. 2015, 5, 68-76. [CrossRef]

91. Weisheit, A.; Dutta, A.; Rittinghaus, S.K.; Majumdar, J.D. Structure-property-process parameters correlation of laser additive manufactured TiC dispersed titanium aluminide (Ti45Al5Nb0.5Si) composite. Intermetallics 2021, 134, 107185. [CrossRef]

92. Gong, X.; Cui, Y.; Wei, D.; Liu, B.; Liu, R.; Nie, Y.; Li, Y. Building direction dependence of corrosion resistance property of Ti-6Al-4V alloy fabricated by electron beam melting. Corros. Sci. 2017, 127, 101-109. [CrossRef]

93. Qiu, W.; Wei, Y.; Chen, A.; Deng, H.; Zhou, L.; Zuo, H.; Chen, L.; Xia, Z.; Wang, H.; Tang, J. Corrosion behavior of additive manufactured Ti-6Al-4V in sulfamic acid cleaning solution. New J. Chem. 2021, 45, 2967-2973. [CrossRef]

94. Yang, J.; Yang, H.; Yu, H.; Wang, Z.; Zeng, X. Corrosion Behavior of Additive Manufactured Ti-6Al-4V Alloy in NaCl Solution. Metall. Mater. Trans. A 2017, 48, 3583-3593. [CrossRef]

95. Mahamood, R.M.; Marvins, T.; Abdulrahman, K.O.; Shuaib-Babata, Y.L.; Adebisi, J.A.; Akinlabi, S.A.; Hassan, S.; Akinlabi, E.T. Metallurgical and Corrosion Property of Additive Manufactured Titanium Alloy-Ti6Al4V. Ann. Dunarea Jos Univ. Galati. Fascicle XII Weld. Equip. Technol. 2020, 31, 43-48. [CrossRef]

96. Dai, N.; Zhang, L.-C.; Zhang, J.; Zhang, X.; Ni, Q.; Chen, Y.; Wu, M.; Yang, C. Distinction in corrosion resistance of selective laser melted Ti-6Al-4V alloy on different planes. Corros. Sci. 2016, 111, 703-710. [CrossRef]

97. Dai, N.; Zhang, L.; Zhang, J.; Chen, Q.; Wu, M. Corrosion behavior of selective laser melted Ti-6Al-4 V alloy in NaCl solution. Corros. Sci. 2016, 102, 484-489. [CrossRef]

98. Dai, N.; Zhang, J.; Chen, Y.; Zhang, L. Heat Treatment Degrading the Corrosion Resistance of Selective Laser Melted Ti-6Al-4V Alloy. J. Electrochem. Soc. 2017, 164, C428-C434. [CrossRef]

99. Chiu, T.-M.; Mahmoudi, M.; Dai, W.; Elwany, A.; Liang, H.; Castaneda, H. Corrosion assessment of Ti-6Al-4V fabricated using laser powder-bed fusion additive manufacturing. Electrochim. Acta 2018, 279, 143-151. [CrossRef]

100. Zhang, L.C.; Qin, P. Corrosion Behaviors of Additive Manufactured Titanium Alloys; Springer: Cham, Germany, 2019.

101. Bai, Y.; Gai, X.; Li, S.; Zhang, L.; Liu, Y.; Hao, Y.; Zhang, X.; Yang, R.; Gao, Y. Improved corrosion behaviour of electron beam melted Ti-6Al-4V alloy in phosphate buffered saline. Corros. Sci. 2017, 123, 289-296. [CrossRef]

102. Chen, J.-R.; Tsai, W.-T. In situ corrosion monitoring of Ti-6Al-4V alloy in $\mathrm{H} 2 \mathrm{SO} 4 / \mathrm{HCl}$ mixed solution using electrochemical AFM. Electrochim. Acta 2011, 56, 1746-1751. [CrossRef]

103. Murata, Y.; Morinaga, M.; Yukawa, N.; Ogawa, H.; Kato, M. Solidification Structures of Inconel 718 with Microalloying Elements. Superalloys 1994, 718, 81-88.

104. Strondl, A.; Fischer, R.; Frommeyer, G.; Schneider, A. Investigations of MX and $\gamma^{\prime} / \gamma^{\prime \prime}$ precipitates in the nickel-based superalloy 718 produced by electron beam melting. Mater. Sci. Eng. A 2008, 480, 138-147. [CrossRef]

105. Bouse, G. Application of a Modified Phase Diagram to the Production of Cast Alloy 718 Components. In Superalloy 718-Metallurgy and Applications; TMS: Pittsburgh, PA, USA, 1989; pp. 69-77. [CrossRef]

106. Murr, L. Metallurgy of additive manufacturing: Examples from electron beam melting. Addit. Manuf. 2015, 5, 40-53. [CrossRef]

107. Hosseini, E.; Popovich, V. A review of mechanical properties of additively manufactured Inconel 718. Addit. Manuf. 2019, 30, 100877. [CrossRef]

108. Kirka, M.M.; Unocic, K.A.; Raghavan, N.; Medina, F.; Dehoff, R.; Babu, S. Microstructure Development in Electron Beam-Melted Inconel 718 and Associated Tensile Properties. JOM 2016, 68, 1012-1020. [CrossRef]

109. Sames, W.J.; Unocic, K.A.; Dehoff, R.; Lolla, T.; Babu, S. Thermal effects on microstructural heterogeneity of Inconel 718 materials fabricated by electron beam melting. J. Mater. Res. 2014, 29, 1920-1930. [CrossRef]

110. Strondl, A.; Palm, M.; Gnauk, J.; Frommeyer, G. Microstructure and mechanical properties of nickel based superalloy IN718 produced by rapid prototyping with electron beam melting (EBM). Mater. Sci. Technol. 2011, 27, 876-883. [CrossRef]

111. Kirka, M.; Greeley, D.; Hawkins, C.; Dehoff, R. Effect of anisotropy and texture on the low cycle fatigue behavior of Inconel 718 processed via electron beam melting. Int. J. Fatigue 2017, 105, 235-243. [CrossRef]

112. Deng, D.; Moverare, J.; Peng, R.L.; Söderberg, H. Microstructure and anisotropic mechanical properties of EBM manufactured Inconel 718 and effects of post heat treatments. Mater. Sci. Eng. A 2017, 693, 151-163. [CrossRef]

113. Dehoff, R.R.; Kirka, M.M.; List, F.A.; Unocic, K.A.; Sames, W.J. Crystallographic texture engineering through novel melt strategies via electron beam melting: Inconel 718. Mater. Sci. Technol. 2015, 31, 939-944. [CrossRef]

114. Deng, D.; Peng, R.L.; Söderberg, H.; Moverare, J. On the formation of microstructural gradients in a nickel-base superalloy during electron beam melting. Mater. Des. 2018, 160, 251-261. [CrossRef]

115. Deng, D. Additively Manufactured Inconel 718: Microstructures and Mechanical Properties; Linköping University Electronic Press: Linköping, Sweden, 2018. 
116. Helmer, H.E.; Körner, C.; Singer, R.F. Additive manufacturing of nickel-based superalloy Inconel 718 by selective electron beam melting: Processing window and microstructure. J. Mater. Res. 2014, 29, 1987-1996. [CrossRef]

117. Goel, S.; Zaninelli, E.; Gundgire, T.; Ahlfors, M.; Ojo, O.; Klement, U.; Joshi, S. Microstructure evolution and mechanical response-based shortening of thermal post-treatment for electron beam melting (EBM) produced Alloy 718. Mater. Sci. Eng. A 2021, 820, 141515. [CrossRef]

118. Balachandramurthi, A.R.; Moverare, J.; Mahade, S.; Pederson, R. Additive Manufacturing of Alloy 718 via Electron Beam Melting: Effect of Post-Treatment on the Microstructure and the Mechanical Properties. Materials 2018, 12, 68. [CrossRef] [PubMed]

119. Goel, S.; Mehtani, H.; Yao, S.-W.; Samajdar, I.; Klement, U.; Joshi, S. As-Built and Post-treated Microstructures of an Electron Beam Melting (EBM) Produced Nickel-Based Superalloy. Metall. Mater. Trans. A 2020, 51, 6546-6559. [CrossRef]

120. List, F.; Dehoff, R.; Lowe, L.; Sames, W. Properties of Inconel 625 mesh structures grown by electron beam additive manufacturing. Mater. Sci. Eng. A 2014, 615, 191-197. [CrossRef]

121. Wang, X.; Keya, T.; Chou, K. Build Height Effect on the Inconel 718 Parts Fabricated by Selective Laser Melting. Procedia Manuf. 2016, 5, 1006-1017. [CrossRef]

122. Pröbstle, M.; Neumeier, S.; Hopfenmüller, J.; Freund, L.; Niendorf, T.; Schwarze, D.; Göken, M. Superior creep strength of a nickel-based superalloy produced by selective laser melting. Mater. Sci. Eng. A 2016, 674, 299-307. [CrossRef]

123. Tillmann, W.; Schaak, C.; Nellesen, J.; Schaper, M.; Aydinöz, M.E.; Niendorf, T. Functional encapsulation of laser melted Inconel 718 by Arc-PVD and HVOF for post compacting by hot isostatic pressing. Powder Metall. 2015, 58, 259-264. [CrossRef]

124. Gong, X.; Chou, K. Microstructures of Inconel 718 by Selective Laser Melting. In Proceedings of the TMS 2015144 th Annual Meeting E Exhibition; Springer: Berlin/Heidelberg, Germany, 2015; pp. 461-468.

125. Brenne, F.; Taube, A.; Pröbstle, M.; Neumeier, S.; Schwarze, D.; Schaper, M.; Niendorf, T. Microstructural design of Ni-base alloys for high-temperature applications: Impact of heat treatment on microstructure and mechanical properties after selective laser melting. Prog. Addit. Manuf. 2016, 1, 141-151. [CrossRef]

126. Aydinöz, M.; Brenne, F.; Schaper, M.; Schaak, C.; Tillmann, W.; Nellesen, J.; Niendorf, T. On the microstructural and mechanical properties of post-treated additively manufactured Inconel 718 superalloy under quasi-static and cyclic loading. Mater. Sci. Eng. A 2016, 669, 246-258. [CrossRef]

127. Wei, H.; Mazumder, J.; Debroy, T. Evolution of solidification texture during additive manufacturing. Sci. Rep. 2015, 5, 16446. [CrossRef]

128. Gong, X.; Wang, X.; Cole, V.; Jones, Z.; Cooper, K.; Chou, K. Characterization of Microstructure and Mechanical Property of Inconel 718 From Selective Laser Melting. In Proceedings of the ASME 2015 International Manufacturing Science and Engineering Conference, Charlotte, NC, USA, 8-12 June 2015; American Society of Mechanical Engineers: New York, NY, USA, 2015; pp. 1-7. [CrossRef]

129. Chlebus, E.; Gruber, K.; Kuźnicka, B.; Kurzac, J.; Kurzynowski, T. Effect of heat treatment on the microstructure and mechanical properties of Inconel 718 processed by selective laser melting. Mater. Sci. Eng. A 2015, 639, 647-655. [CrossRef]

130. Wang, X.; Chou, Y.K. A Method to Estimate Residual Stress in Metal Parts Made by Selective Laser Melting. Biomed. Biotechnol. Eng. 2015, 2A-2015, 1-8. [CrossRef]

131. Parimi, L.L.; Ravi, G.A.; Clark, D.; Attallah, M.M. Microstructural and texture development in direct laser fabricated IN718. Mater. Charact. 2014, 89, 102-111. [CrossRef]

132. Sadowski, M.; Ladani, L.; Brindley, W.; Romano, J. Optimizing quality of additively manufactured Inconel 718 using powder bed laser melting process. Addit. Manuf. 2016, 11, 60-70. [CrossRef]

133. Sames, W.; Medina, F.; Peter, W.; Babu, S.; Dehoff, R. Effect of Process Control and Powder Quality on Inconel 718 Produced Using Electron Beam Melting. In Proceedings of the 8th International Symposium on Superalloy 718 and Derivatives, Pittsburgh, PA, USA, 28 September-1 October 2014; Wiley: Hoboken, NJ, USA, 2014; pp. 409-423.

134. Huang, W.; Yang, J.; Yang, H.; Jing, G.; Wang, Z.; Zeng, X. Heat treatment of Inconel 718 produced by selective laser melting: Microstructure and mechanical properties. Mater. Sci. Eng. A 2019, 750, 98-107. [CrossRef]

135. Zhao, J.-R.; Hung, F.-Y.; Lui, T.-S. Microstructure and tensile fracture behavior of three-stage heat treated inconel 718 alloy produced via laser powder bed fusion process. J. Mater. Res. Technol. 2020, 9, 3357-3367. [CrossRef]

136. Nadammal, N.; Cabeza, S.; Mishurova, T.; Thiede, T.; Kromm, A.; Seyfert, C.; Farahbod, L.; Haberland, C.; Schneider, J.A.; Portella, P.D.; et al. Effect of hatch length on the development of microstructure, texture and residual stresses in selective laser melted superalloy Inconel 718. Mater. Des. 2017, 134, 139-150. [CrossRef]

137. Popovich, V.; Borisov, E.; Sufiiarov, V.; Masaylo, D.; Alzina, L. Functionally graded Inconel 718 processed by additive manufacturing: Crystallographic texture, anisotropy of microstructure and mechanical properties. Mater. Des. 2017, 114, 441-449. [CrossRef]

138. Mostafa, A.; Rubio, I.P.; Brailovski, V.; Jahazi, M.; Medraj, M. Structure, Texture and Phases in 3D Printed IN718 Alloy Subjected to Homogenization and HIP Treatments. Metals 2017, 7, 196. [CrossRef]

139. Schaak, C.; Tillmann, W.; Schaper, M.; Aydinöz, M.E. Process Gas Infiltration in Inconel 718 Samples during SLM Processing. RTeJ.-Fachforum Rapid Technol. 2016, 13, 1-8.

140. Mumtaz, K.; Hopkinson, N. Top surface and side roughness of Inconel 625 parts processed using selective laser melting. Rapid Prototyp. J. 2009, 15, 96-103. [CrossRef] 
141. Yadroitsev, I.; Thivillon, L.; Bertrand, P.; Smurov, I. Strategy of manufacturing components with designed internal structure by selective laser melting of metallic powder. Appl. Surf. Sci. 2007, 254, 980-983. [CrossRef]

142. Turker, M.; Godlinski, D.; Petzoldt, F. Effect of production parameters on the properties of IN 718 superalloy by three-dimensional printing. Mater. Charact. 2008, 59, 1728-1735. [CrossRef]

143. Kim, K.-S.; Kang, T.-H.; Kassner, M.E.; Son, K.-T.; Lee, K.-A. High-temperature tensile and high cycle fatigue properties of inconel 625 alloy manufactured by laser powder bed fusion. Addit. Manuf. 2020, 35, 101377. [CrossRef]

144. Qin, S.; Novak, T.C.; Vailhe, M.K.; Liu, Z.-K.; Beese, A.M. Plasticity and fracture behavior of Inconel 625 manufactured by laser powder bed fusion: Comparison between as-built and stress relieved conditions. Mater. Sci. Eng. A 2021, 806, 140808. [CrossRef]

145. Marchese, G.; Parizia, S.; Rashidi, M.; Saboori, A.; Manfredi, D.; Ugues, D.; Lombardi, M.; Hryha, E.; Biamino, S. The role of texturing and microstructure evolution on the tensile behavior of heat-treated Inconel 625 produced via laser powder bed fusion. Mater. Sci. Eng. A 2020, 769, 138500. [CrossRef]

146. Kanagarajah, P.; Brenne, F.; Niendorf, T.; Maier, H. Inconel 939 processed by selective laser melting: Effect of microstructure and temperature on the mechanical properties under static and cyclic loading. Mater. Sci. Eng. A 2013, 588, 188-195. [CrossRef]

147. Raza, M.M.; Lo, Y.-L. Experimental investigation into microstructure, mechanical properties, and cracking mechanism of IN713LC processed by laser powder bed fusion. Mater. Sci. Eng. A 2021, 819, 141527. [CrossRef]

148. Rickenbacher, L.; Etter, T.; Hovel, S.; Wegener, K. High temperature material properties of IN738LC processed by selective laser melting (SLM) technology. Rapid Prototyp. J. 2013, 19, 282-290. [CrossRef]

149. Yadroitsev, I.; Gusarov, A.; Yadroitsava, I.; Smurov, I. Single track formation in selective laser melting of metal powders. J. Mater. Process. Technol. 2010, 210, 1624-1631. [CrossRef]

150. Nilsson, E.; Johansson, D. Testing and Evaluation of Component Made Using Electron Beam Melting and Alloy 718 Powder. Bachelor's Thesis, Mälardalens University, Västerås, Sweden, 15 May 2017.

151. Cakmak, E.; Watkins, T.; Bunn, J.R.; Cooper, R.; Cornwell, P.A.; Wang, Y.; Sochalski-Kolbus, L.M.; Dehoff, R.; Babu, S. Mechanical Characterization of an Additively Manufactured Inconel 718 Theta-Shaped Specimen. Metall. Mater. Trans. A 2016, 47, 971-980. [CrossRef]

152. Sames, W. Additive Manufacturing of Inconel 718 Using Electron Beam Melting: Processing, Post-Processing, E Mechanical Properties; Texas A \& M University: College Station, TX, USA, 2015.

153. Kirka, M.M.; Medina, F.; Dehoff, R.; Okello, A. Mechanical behavior of post-processed Inconel 718 manufactured through the electron beam melting process. Mater. Sci. Eng. A 2017, 680, 338-346. [CrossRef]

154. Shassere, B.; Greeley, D.; Okello, A.; Kirka, M.; Nandwana, P.; Dehoff, R. Correlation of Microstructure to Creep Response of Hot Isostatically Pressed and Aged Electron Beam Melted Inconel 718. Metall. Mater. Trans. A 2018, 49, 5107-5117. [CrossRef]

155. Szustecki, M.; Zrodowski, L.; Sitek, R.; Cygan, R. Microstructure and Properties of IN 718 Nickel-Based superalloy Man-ufactured by Means of selective Laser Melting. Adv. Appl. Plasma Sci. 2017, 17, 3-7.

156. Raghavan, S.; Zhang, B.; Wang, P.; Sun, C.-N.; Nai, M.L.S.; Li, T.; Wei, J. Effect of different heat treatments on the microstructure and mechanical properties in selective laser melted INCONEL 718 alloy. Mater. Manuf. Process. 2016, 32, 1588-1595. [CrossRef]

157. Ni, M.; Chen, C.; Wang, X.; Wang, P.; Li, R.; Zhang, X.; Zhou, K. Anisotropic tensile behavior of in situ precipitation strengthened Inconel 718 fabricated by additive manufacturing. Mater. Sci. Eng. A 2017, 701, 344-351. [CrossRef]

158. Kuo, Y.-L.; Horikawa, S.; Kakehi, K. Effects of build direction and heat treatment on creep properties of Ni-base superalloy built up by additive manufacturing. Scr. Mater. 2017, 129, 74-78. [CrossRef]

159. Ivanov, D.; Travyanov, A.; Petrovskiy, P.; Cheverikin, V.; Alekseeva, E.; Khvan, A.; Logachev, I. Evolution of structure and properties of the nickel-based alloy EP718 after the SLM growth and after different types of heat and mechanical treatment. Addit. Manuf. 2017, 18, 269-275. [CrossRef]

160. Brenne, F.; Leuders, S.; Niendorf, T. On the Impact of Additive Manufacturing on Microstructural and Mechanical Properties of Stainless Steel and Ni-base Alloys. BHM Berg-Und Hüttenmännische Mon. 2017, 162, 199-202. [CrossRef]

161. Konečná, R.; Kunz, L.; Nicoletto, G.; Bača, A. Long fatigue crack growth in Inconel 718 produced by selective laser melting. Int. J. Fatigue 2016, 92, 499-506. [CrossRef]

162. Zhang, D.; Niu, W.; Cao, X.; Liu, Z. Effect of standard heat treatment on the microstructure and mechanical properties of selective laser melting manufactured Inconel 718 superalloy. Mater. Sci. Eng. A 2015, 644, 32-40. [CrossRef]

163. Cheng, B.; Shrestha, S.; Chou, K. Stress and deformation evaluations of scanning strategy effect in selective laser melting. Addit. Manuf. 2016, 12, 240-251. [CrossRef]

164. Strößner, J.; Terock, M.; Glatzel, U. Mechanical and Microstructural Investigation of Nickel-Based Superalloy IN718 Manufactured by Selective Laser Melting (SLM). Adv. Eng. Mater. 2015, 17, 1099-1105. [CrossRef]

165. Popovich, A.A.; Sufiiarov, V.S.; Polozov, I.A.; Borisov, E. Microstructure and Mechanical Properties of Inconel 718 Produced by SLM and Subsequent Heat Treatment. Key Eng. Mater. 2015, 651-653, 665-670. [CrossRef]

166. Lambert, D.; Adler, M. IN718 Additive Manufacturing Properties and Influences. Addit. Manuf. Consort. Meet. 2014, 7, 1-23. Available online: http:/ / ntrs.nasa.gov/search.jsp?R=20140016887 (accessed on 25 August 2021).

167. Wang, Z.; Guan, K.; Gao, M.; Li, X.; Chen, X.; Zeng, X. The microstructure and mechanical properties of deposited-IN718 by selective laser melting. J. Alloys Compd. 2012, 513, 518-523. [CrossRef]

168. Smith, D.H.; Bicknell, J.; Jorgensen, L.; Patterson, B.; Cordes, N.; Tsukrov, I.; Knezevic, M. Microstructure and mechanical behavior of direct metal laser sintered Inconel alloy 718. Mater. Charact. 2016, 113, 1-9. [CrossRef] 
169. Konečná, R.; Nicoletto, G.; Kunz, L.; Bača, A. Microstructure and directional fatigue behavior of Inconel 718 produced by selective laser melting. Procedia Struct. Integr. 2016, 2, 2381-2388. [CrossRef]

170. Gribbin, S.; Bicknell, J.; Jorgensen, L.; Tsukrov, I.; Knezevic, M. Low cycle fatigue behavior of direct metal laser sintered Inconel alloy 718. Int. J. Fatigue 2016, 93, 156-167. [CrossRef]

171. Lu, Y.; Wu, S.; Gan, Y.; Huang, T.; Yang, C.; Junjie, L.; Lin, J. Study on the microstructure, mechanical property and residual stress of SLM Inconel-718 alloy manufactured by differing island scanning strategy. Opt. Laser Technol. 2015, 75, 197-206. [CrossRef]

172. Ardila, L.; Garciandia, F.; González-Díaz, J.; Álvarez, P.; Echeverria, A.; Petite, M.; Deffley, R.; Ochoa, J. Effect of IN718 Recycled Powder Reuse on Properties of Parts Manufactured by Means of Selective Laser Melting. Phys. Procedia 2014, 56, 99-107. [CrossRef]

173. Amato, K.; Gaytan, S.; Murr, L.; Martinez, E.; Shindo, P.; Hernandez, J.; Collins, S.; Medina, F. Microstructures and mechanical behavior of Inconel 718 fabricated by selective laser melting. Acta Mater. 2012, 60, 2229-2239. [CrossRef]

174. Popovich, V.; Borisov, E.; Sufiiarov, V.; Masaylo, D.; Alzina, L. Impact of heat treatment on mechanical behaviour of Inconel 718 processed with tailored microstructure by selective laser melting. Mater. Des. 2017, 131, 12-22. [CrossRef]

175. Soller, S.; Barata, A.; Beyer, S.; Dahlhaus, A.; Guichard, D.; Humbert, E.; Kretschmer, J.; Zeiss, W. Selective Laser Melting of Inconel 718 and Stainless Steel Injectors for Liquid Rocket Engines. In Space Propulsion 2016 Proceedings; 2016; pp. 1-10. Available online: https:/ / www.researchgate.net/publication/303331194 (accessed on 25 August 2021).

176. Trosch, T.; Strößner, J.; Völkl, R.; Glatzel, U. Microstructure and mechanical properties of selective laser melted Inconel 718 compared to forging and casting. Mater. Lett. 2016, 164, 428-431. [CrossRef]

177. Tucho, W.; Cuvillier, P.; Sjolyst-Kverneland, A.; Hansen, V. Microstructure and hardness studies of Inconel 718 manufactured by selective laser melting before and after solution heat treatment. Mater. Sci. Eng. A 2017, 689, 220-232. [CrossRef]

178. Pei, C.; Zeng, W.; Yuan, H. A damage evolution model based on micro-structural characteristics for an additive manufactured superalloy under monotonic and cyclic loading conditions. Int. J. Fatigue 2020, 131, 105279. [CrossRef]

179. Komarasamy, M.; Shukla, S.; Williams, S.; Kandasamy, K.; Kelly, S.; Mishra, R.S. Microstructure, fatigue, and impact toughness properties of additively manufactured nickel alloy 718. Addit. Manuf. 2019, 28, 661-675. [CrossRef]

180. Yadollahi, A.; Shamsaei, N. Additive manufacturing of fatigue resistant materials: Challenges and opportunities. Int. J. Fatigue 2017, 98, 14-31. [CrossRef]

181. Wan, H.-Y.; Zhou, Z.-J.; Li, C.-P.; Chen, G.-F.; Zhang, G.-P. Enhancing Fatigue Strength of Selective Laser Melting-Fabricated Inconel 718 by Tailoring Heat Treatment Route. Adv. Eng. Mater. 2018, 20, 1800307. [CrossRef]

182. Sui, S.; Chen, J.; Fan, E.; Yang, H.; Lin, X.; Huang, W. The influence of Laves phases on the high-cycle fatigue behavior of laser additive manufactured Inconel 718. Mater. Sci. Eng. A 2017, 695, 6-13. [CrossRef]

183. Balachandramurthi, A.R.; Moverare, J.; Dixit, N.; Pederson, R. Influence of defects and as-built surface roughness on fatigue properties of additively manufactured Alloy 718. Mater. Sci. Eng. A 2018, 735, 463-474. [CrossRef]

184. Klapper, H.S.; Molodtsov, N.; Burns, M.; Wangenheim, C. Critical factors affecting the pitting corrosion resistance of additively manufactured nickel alloy in chloride containing environments. NACE_Int. Corros. Conf. Ser. 2017, 2, 1205-1212.

185. Cabrini, M.; Lorenzi, S.; Testa, C.; Pastore, T.; Brevi, F.; Biamino, S.; Fino, P.; Manfredi, D.; Marchese, G.; Calignano, F.; et al. Evaluation of Corrosion Resistance of Alloy 625 Obtained by Laser Powder Bed Fusion. J. Electrochem. Soc. 2019, 166, C3399-C3408. [CrossRef]

186. Hack, H.; Olig, S.; Knudsen, E.; Link, R.; Beckwith, A.; Arcari, A. Fatigue and Corrosion Fatigue Properties of AdditiveManufactured Nickel Alloy 625 and Ti-6Al-4V. Mater. Perform. Charact. 2018, 7, 456-467. [CrossRef]

187. Zadi-Maad, A.; Rohib, R.; Irawan, A. Additive manufacturing for steels: A review. IOP Conf. Ser. Mater. Sci. Eng. 2018, $285,12028$. [CrossRef]

188. Mazur, M.; Brincat, P.; Leary, M.; Brandt, M. Numerical and experimental evaluation of a conformally cooled H13 steel injection mould manufactured with selective laser melting. Int. J. Adv. Manuf. Technol. 2017, 93, 881-900. [CrossRef]

189. Badrossamay, M.; Childs, T. Further studies in selective laser melting of stainless and tool steel powders. Int. J. Mach. Tools Manuf. 2007, 47, 779-784. [CrossRef]

190. Hao, L.; Dadbakhsh, S.; Seaman, O.; Felstead, M. Selective laser melting of a stainless steel and hydroxyapatite composite for load-bearing implant development. J. Mater. Process. Technol. 2009, 209, 5793-5801. [CrossRef]

191. Taha, M.A.; Yousef, A.F.; Gany, K.A.; Sabour, H.A. On selective laser melting of ultra high carbon steel: Effect of scan speed and post heat treatment. Mater. Werkst. 2012, 43, 913-923. [CrossRef]

192. Abe, F.; Osakada, K.; Shiomi, M.; Uematsu, K.; Matsumoto, M. The manufacturing of hard tools from metallic powders by selective laser melting. J. Mater. Process. Technol. 2001, 111, 210-213. [CrossRef]

193. Zhong, Y.; Rännar, L.-E.; Liu, L.; Koptyug, A.; Wikman, S.; Olsen, J.; Cui, D.; Shen, Z. Additive manufacturing of 316L stainless steel by electron beam melting for nuclear fusion applications. J. Nucl. Mater. 2017, 486, 234-245. [CrossRef]

194. Qi, H.B.; Yan, Y.N.; Lin, F.; He, W.; Zhang, R.J. Direct metal part forming of 316L stainless steel powder by electron beam selective melting. Proc. Inst. Mech. Eng. Part B J. Eng. Manuf. 2006, 220, 1845-1853. [CrossRef]

195. Yadroitsev, I.; Bertrand, P.; Smurov, I. Parametric analysis of the selective laser melting process. Appl. Surf. Sci. 2007, 253, 8064-8069. [CrossRef]

196. Spierings, A.; Herres, N.; Levy, G.J. Influence of the particle size distribution on surface quality and mechanical properties in AM steel parts. Rapid Prototyp. J. 2011, 17, 195-202. [CrossRef] 
197. Brown, B. Characterization of 304L Stainless Steel by Means of Minimum Input Energy on the Selective Laser Melting Platform. Master's Thesis, Missouri University of Science and Technology, Rolla, MO, USA, 2015. Available online: http://scholarsmine. mst.edu/masters_theses (accessed on 25 August 2021).

198. Simchi, A. Direct laser sintering of metal powders: Mechanism, kinetics and microstructural features. Mater. Sci. Eng. A 2006, 428, 148-158. [CrossRef]

199. Delgado, J.; Ciurana, J.; Rodríguez, C.A. Influence of process parameters on part quality and mechanical properties for DMLS and SLM with iron-based materials. Int. J. Adv. Manuf. Technol. 2012, 60, 601-610. [CrossRef]

200. Olsén, J.; Shen, Z.; Liu, L.; Koptyug, A.; Rännar, L.-E. Micro- and macro-structural heterogeneities in 316L stainless steel prepared by electron-beam melting. Mater. Charact. 2018, 141, 1-7. [CrossRef]

201. Rännar, L.-E.; Koptyug, A.; Olsén, J.; Saeidi, K.; Shen, Z. Hierarchical structures of stainless steel 316L manufactured by Electron Beam Melting. Addit. Manuf. 2017, 17, 106-112. [CrossRef]

202. Jamshidinia, M.; Sadek, A.; Wang, W.; Kelly, S. Additive manufacturing of steel alloys using laser powder-bed fusion. Adv. Mater. Process. 2015, 173, 20-24.

203. Laleh, M.; Hughes, A.E.; Xu, W.; Haghdadi, N.; Wang, K.; Cizek, P.; Gibson, I.; Tan, M.Y. On the unusual intergranular corrosion resistance of 316L stainless steel additively manufactured by selective laser melting. Corros. Sci. 2019, 161, 108189. [CrossRef]

204. Niendorf, T.; Leuders, S.; Riemer, A.; Richard, H.A.; Tröster, T.; Schwarze, D. Highly Anisotropic Steel Processed by Selective Laser Melting. Metall. Mater. Trans. A 2013, 44, 794-796. [CrossRef]

205. Cheruvathur, S.; Lass, E.A.; Campbell, C.E. Additive Manufacturing of 17-4 PH Stainless Steel: Post-processing Heat Treatment to Achieve Uniform Reproducible Microstructure. JOM 2016, 68, 930-942. [CrossRef]

206. Sun, Y.; Hebert, R.J.; Aindow, M. Effect of heat treatments on microstructural evolution of additively manufactured and wrought 17-4PH stainless steel. Mater. Des. 2018, 156, 429-440. [CrossRef]

207. Al-Mangour, B.; Grzesiak, D.; Yang, J.-M. Rapid fabrication of bulk-form TiB2/316L stainless steel nanocomposites with novel reinforcement architecture and improved performance by selective laser melting. J. Alloys Compd. 2016, 680, 480-493. [CrossRef]

208. Al-Mangour, B.; Grzesiak, D.; Yang, J.-M. Selective laser melting of TiC reinforced 316L stainless steel matrix nanocomposites: Influence of starting TiC particle size and volume content. Mater. Des. 2016, 104, 141-151. [CrossRef]

209. Gorsse, S.; Hutchinson, C.; Gouné, M.; Banerjee, R. Additive manufacturing of metals: A brief review of the characteristic microstructures and properties of steels, Ti-6Al-4V and high-entropy alloys. Sci. Technol. Adv. Mater. 2017, 18, 584-610. [CrossRef] [PubMed]

210. Silva, A.L.V.D.C.E. Non-metallic inclusions in steels-Origin and control. J. Mater. Res. Technol. 2018, 7, 283-299. [CrossRef]

211. Haghdadi, N.; Laleh, M.; Moyle, M.; Primig, S. Additive manufacturing of steels: A review of achievements and challenges. J. Mater. Sci. 2021, 56, 64-107. [CrossRef]

212. Saeidi, K.; Kevetkova, L.; Lofaj, F.; Shen, Z. Novel ferritic stainless steel formed by laser melting from duplex stainless steel powder with advanced mechanical properties and high ductility. Mater. Sci. Eng. A 2016, 665, 59-65. [CrossRef]

213. Al-Mangour, B.; Grzesiak, D.; Yang, J.-M. Scanning strategies for texture and anisotropy tailoring during selective laser melting of TiC/316L stainless steel nanocomposites. J. Alloys Compd. 2017, 728, 424-435. [CrossRef]

214. Gao, R.; Zeng, L.; Ding, H.; Zhang, T.; Wang, X.; Fang, Q. Characterization of oxide dispersion strengthened ferritic steel fabricated by electron beam selective melting. Mater. Des. 2016, 89, 1171-1180. [CrossRef]

215. Wang, Y.M.; Voisin, T.; McKeown, J.; Ye, J.; Calta, N.; Li, Z.; Zeng, Z.; Zhang, Y.; Chen, W.; Roehling, T.T.; et al. Additively manufactured hierarchical stainless steels with high strength and ductility. Nat. Mater. 2018, 17, 63-71. [CrossRef] [PubMed]

216. Sun, Z.; Tan, X.; Tor, S.B.; Chua, C.K. Simultaneously enhanced strength and ductility for 3D-printed stainless steel 316L by selective laser melting. NPG Asia Mater. 2018, 10, 127-136. [CrossRef]

217. Roberts, D.; Zhang, Y.; Charit, I.; Zhang, J. A comparative study of microstructure and high-temperature mechanical properties of 15-5 PH stainless steel processed via additive manufacturing and traditional manufacturing. Prog. Addit. Manuf. 2018, 3, 183-190. [CrossRef]

218. Rafi, H.K.; Starr, T.L.; Stucker, B.E. A comparison of the tensile, fatigue, and fracture behavior of Ti-6Al-4V and 15-5 PH stainless steel parts made by selective laser melting. Int. J. Adv. Manuf. Technol. 2013, 69, 1299-1309. [CrossRef]

219. Kempen, K.; Yasa, E.; Thijs, L.; Kruth, J.-P.; Van Humbeeck, J. Microstructure and mechanical properties of Selective Laser Melted 18Ni-300 steel. Phys. Procedia 2011, 12, 255-263. [CrossRef]

220. Kučerová, L.; Zetkova, I.; Jandová, A.; Bystrianský, M. Microstructural characterisation and in-situ straining of additivemanufactured X3NiCoMoTi 18-9-5 maraging steel. Mater. Sci. Eng. A 2019, 750, 70-80. [CrossRef]

221. Saeidi, K.; Zapata, D.L.; Lofaj, F.; Kvetkova, L.; Olsen, J.; Shen, Z.; Akhtar, F. Ultra-high strength martensitic 420 stainless steel with high ductility. Addit. Manuf. 2019, 29, 100803. [CrossRef]

222. Haase, C.; Bültmann, J.; Hof, J.; Ziegler, S.; Bremen, S.; Hinke, C.; Schwedt, A.; Prahl, U.; Bleck, W. Exploiting Process-Related Advantages of Selective Laser Melting for the Production of High-Manganese Steel. Materials 2017, 10, 56. [CrossRef]

223. Lebrun, T.; Tanigaki, K.; Horikawa, K.; Kobayashi, H. Strain rate sensitivity and mechanical anisotropy of selective laser melted 17-4 PH stainless steel. Mech. Eng. J. 2014, 1, SMM0049. [CrossRef]

224. Kumpaty, S.; Kamara, S.; Tomlin, B.; Yoo, J.; Kumpaty, H.; Anderson, D.; Govindaraju, M.; Kanoongo, N.; Balasubramanian, K. Effect of Heat Treatment on Mechanical/Metallurgical Properties of Direct Metal Laser Sintered 17-4 Precipitate Hardened Stainless Steel. Adv. Mater. Res. 2013, 699, 795-801. [CrossRef] 
225. Mahmoudi, M.; Elwany, A.; Yadollahi, A.; Thompson, S.M.; Bian, L.; Shamsaei, N. Mechanical properties and microstructural characterization of selective laser melted 17-4 PH stainless steel. Rapid Prototyp. J. 2017, 23, 280-294. [CrossRef]

226. Auguste, P.; Mauduit, A.; Fouquet, L.; Pillot, S. Study on 17-4 PH stainless steel produced by selective laser melting. UPB Sci. Bull. Ser. B Chem. Mater. Sci. 2018, 80, 197-210.

227. Pasebani, S.; Ghayoor, M.; Badwe, S.; Irrinki, H.; Atre, S.V. Effects of atomizing media and post processing on mechanical properties of 17-4 PH stainless steel manufactured via selective laser melting. Addit. Manuf. 2018, 22, 127-137. [CrossRef]

228. Lass, E.A.; Stoudt, M.R.; Williams, M.E. Additively Manufactured Nitrogen-Atomized 17-4 PH Stainless Steel with Mechanical Properties Comparable to Wrought. Metall. Mater. Trans. A 2019, 50, 1619-1624. [CrossRef]

229. Yasa, E.; Kempen, K.; Kruth, J.; Thijs, L.; Van Humbeeck, J. Microstructure and mechanical properties of maraging steel 300 after selective laser melting. In Solid Freeform Fabrication Symposium Proceedings; University of Texas at Austin: Austin, TX, USA, 2010; pp. 383-396.

230. Casati, R.; Lemke, J.N.; Tuissi, A.; Vedani, M. Aging Behaviour and Mechanical Performance of 18-Ni 300 Steel Processed by Selective Laser Melting. Metals 2016, 6, 218. [CrossRef]

231. Davidson, K.; Singamneni, S. Selective Laser Melting of Duplex Stainless Steel Powders: An Investigation. Mater. Manuf. Process. 2016, 31, 1543-1555. [CrossRef]

232. Pham, M.-S.; Dovgyy, B.; Hooper, P. Twinning induced plasticity in austenitic stainless steel 316L made by additive manufacturing. Mater. Sci. Eng. A 2017, 704, 102-111. [CrossRef]

233. Riemer, A.; Leuders, S.; Thöne, M.; Richard, H.; Tröster, T.; Niendorf, T. On the fatigue crack growth behavior in 316L stainless steel manufactured by selective laser melting. Eng. Fract. Mech. 2014, 120, 15-25. [CrossRef]

234. Pegues, J.W.; Roach, M.D.; Shamsaei, N. Additive manufacturing of fatigue resistant austenitic stainless steels by understanding process-structure-property relationships. Mater. Res. Lett. 2020, 8, 8-15. [CrossRef]

235. Alvi, S.; Saeidi, K.; Akhtar, F. High temperature tribology and wear of selective laser melted (SLM) 316L stainless steel. Wear 2020, 448-449, 203228. [CrossRef]

236. Bartolomeu, F.; Buciumeanu, M.; Pinto, E.; Alves, N.; Carvalho, O.; Silva, F.; Miranda, G. 316L stainless steel mechanical and tribological behavior-A comparison between selective laser melting, hot pressing and conventional casting. Addit. Manuf. 2017, 16, 81-89. [CrossRef]

237. Sagar, S.; Zhang, Y.; Wu, L.; Park, H.-Y.; Lee, J.-H.; Jung, Y.-G.; Zhang, J. Room-Temperature Charpy Impact Property of 3D-Printed 15-5 Stainless Steel. J. Mater. Eng. Perform. 2017, 27, 52-56. [CrossRef]

238. Croccolo, D.; De Agostinis, M.; Fini, S.; Olmi, G.; Bogojevic, N.; Ciric-Kostic, S. Effects of build orientation and thickness of allowance on the fatigue behaviour of 15-5 PH stainless steel manufactured by DMLS. Fatigue Fract. Eng. Mater. Struct. 2017, 41, 900-916. [CrossRef]

239. Carneiro, L.; Jalalahmadi, B.; Ashtekar, A.; Jiang, Y. Cyclic deformation and fatigue behavior of additively manufactured 17-4 PH stainless steel. Int. J. Fatigue 2019, 123, 22-30. [CrossRef]

240. Nezhadfar, P.D.; Shrestha, R.; Phan, N.; Shamsaei, N. Fatigue behavior of additively manufactured 17-4 PH stainless steel: Synergistic effects of surface roughness and heat treatment. Int. J. Fatigue 2019, 124, 188-204. [CrossRef]

241. Yadollahi, A.; Shamsaei, N.; Thompson, S.M.; Elwany, A.; Bian, L. Effects of building orientation and heat treatment on fatigue behavior of selective laser melted 17-4 PH stainless steel. Int. J. Fatigue 2017, 94, 218-235. [CrossRef]

242. Damon, J.; Hanemann, T.; Dietrich, S.; Graf, G.; Lang, K.-H.; Schulze, V. Orientation dependent fatigue performance and mechanisms of selective laser melted maraging steel X3NiCoMoTi18-9-5. Int. J. Fatigue 2019, 127, 395-402. [CrossRef]

243. Meneghetti, G.; Rigon, D.; Gennari, C. An analysis of defects influence on axial fatigue strength of maraging steel specimens produced by additive manufacturing. Int. J. Fatigue 2019, 118, 54-64. [CrossRef]

244. Branco, R.; Costa, J.; Berto, F.; Razavi, S.M.J.; Ferreira, J.A.M.; Capela, C.; Santos, L.; Antunes, F. Low-Cycle Fatigue Behaviour of AISI 18Ni300 Maraging Steel Produced by Selective Laser Melting. Metals 2018, 8, 32. [CrossRef]

245. Sridharan, N.; Field, K. A Road Map for the Advanced Manufacturing of Ferritic-Martensitic Steels. Fusion Sci. Technol. 2019, 75, 264-274. [CrossRef]

246. Liu, F.; Lin, X.; Shi, J.; Zhang, Y.; Bian, P.; Li, X.; Hu, Y. Effect of microstructure on the Charpy impact properties of directed energy deposition 300M steel. Addit. Manuf. 2019, 29, 100795. [CrossRef]

247. Sridharan, N.; Gussev, M.N.; Field, K.G. Performance of a ferritic/martensitic steel for nuclear reactor applications fabricated using additive manufacturing. J. Nucl. Mater. 2019, 521, 45-55. [CrossRef]

248. Chao, Q.; Cruz, V.; Thomas, S.; Birbilis, N.; Collins, P.; Taylor, A.; Hodgson, P.D.; Fabijanic, D. On the enhanced corrosion resistance of a selective laser melted austenitic stainless steel. Scr. Mater. 2017, 141, 94-98. [CrossRef]

249. Sander, G.; Thomas, S.; Cruz, V.; Jurg, M.; Birbilis, N.; Gao, X.; Brameld, M.; Hutchinson, C.R. On the Corrosion and Metastable Pitting Characteristics of 316L Stainless Steel Produced by Selective Laser Melting. J. Electrochem. Soc. 2017, 164, C250-C257. [CrossRef]

250. Laleh, M.; Hughes, A.E.; Xu, W.; Gibson, I.; Tan, M.Y. Unexpected erosion-corrosion behaviour of 316L stainless steel produced by selective laser melting. Corros. Sci. 2019, 155, 67-74. [CrossRef]

251. Laleh, M.; Hughes, A.E.; Xu, W.; Cizek, P.; Tan, M.Y. Unanticipated drastic decline in pitting corrosion resistance of additively manufactured 316L stainless steel after high-temperature post-processing. Corros. Sci. 2020, 165, 108412. [CrossRef] 
252. Ni, X.; Kong, D.; Wu, W.; Zhang, L.; Dong, C.; He, B.; Lu, L.; Wu, K.; Zhu, D. Corrosion Behavior of 316L Stainless Steel Fabricated by Selective Laser Melting Under Different Scanning Speeds. J. Mater. Eng. Perform. 2018, 27, 3667-3677. [CrossRef]

253. Schaller, R.F.; Mishra, A.; Rodelas, J.M.; Taylor, J.M.; Schindelholz, E.J. The Role of Microstructure and Surface Finish on the Corrosion of Selective Laser Melted 304L. J. Electrochem. Soc. 2018, 165, C234-C242. [CrossRef]

254. Kong, D.; Dong, C.; Ni, X.; Zhang, L.; Luo, H.; Li, R.; Wang, L.; Man, C.; Li, X. Superior resistance to hydrogen damage for selective laser melted 316L stainless steel in a proton exchange membrane fuel cell environment. Corros. Sci. 2020, 166, 108425. [CrossRef]

255. Baek, S.-W.; Song, E.J.; Kim, J.H.; Jung, M.; Baek, U.B.; Nahm, S.H. Hydrogen embrittlement of 3-D printing manufactured austenitic stainless steel part for hydrogen service. Scr. Mater. 2017, 130, 87-90. [CrossRef]

256. Schaller, R.F.; Taylor, J.M.; Rodelas, J.; Schindelholz, E.J. Corrosion Properties of Powder Bed Fusion Additively Manufactured 17-4 PH Stainless Steel. Corrosion 2017, 73, 796-807. [CrossRef]

257. Stoudt, M.R.; Ricker, R.E.; Lass, E.; Levine, L.E. Influence of Postbuild Microstructure on the Electrochemical Behavior of Additively Manufactured 17-4 PH Stainless Steel. JOM 2017, 69, 506-515. [CrossRef] [PubMed]

258. Irrinki, H.; Harper, T.; Badwe, S.; Stitzel, J.; Gulsoy, O.; Gupta, G.; Atre, S.V. Effects of powder characteristics and processing conditions on the corrosion performance of 17-4 PH stainless steel fabricated by laser-powder bed fusion. Prog. Addit. Manuf. 2018, 3, 39-49. [CrossRef]

259. Taminger, K.; Hafley, R.A. Characterization of 2219 Aluminum Produced by Electron Beam Freeform Fabrication; Karen, M., Taminger, B., Robert, A., Eds.; Hafley NASA Langley Research Center: Hampton, VA, USA, 2002; pp. 482-489. Available online: https: / / ntrs.nasa.gov / search.jsp?R=20030012702\&qs=Nm\%3D4293962372\%7CAuthor\%7CDicus\%2C\%2520Dennis\%2520L.\%7 C\%7C4293921627\%7CAuthor\%7CHafley\%2C\%2520Robert\%2520A.\%7C\%7C4293459370\%7CAuthor\%7CTaminger\%2C\%2520 Karen\%2520M.\%2520B.\%7C\%7C4294966788\%7CNASA\%2520Center (accessed on 25 August 2021).

260. Frigola, P.; Agustsson, R.; Boucher, S.; Murokh, A.; Rosenzweig, J.; Travish, G.; Faillace, L.; Cormier, D.; Mahale, T. A novel fabrication technique for the production of RF photoinjectors. In EPAC 2008-Contributions to the Proceedings; University of Texas: Austin, TX, USA, 2008; pp. 751-753.

261. Mahela, T.; Cormier, D.; Harrysson, O.; Ervin, K. Advances In electron beam melting of aluminum alloys. In 2007 International Solid Freeform Fabrication Symposium; University of Texas at Austin: Austin, TX, USA, 2007; pp. 312-323.

262. Mahale, T.R. Electron Beam Melting of Advanced Materials and Structures; North Carolina State University: Raleigh, NC, USA, 2009.

263. Kenevisi, M.S.; Lin, F. Selective electron beam melting of high strength Al2024 alloy; microstructural characterization and mechanical properties. J. Alloys Compd. 2020, 843, 155866. [CrossRef]

264. Liu, Z.; Zhang, D.; Sing, S.L.; Chua, C.K.; Loh, L. Interfacial characterization of SLM parts in multi-material processing: Metallurgical diffusion between 316L stainless steel and C18400 copper alloy. Mater. Charact. 2014, 94, 116-125. [CrossRef]

265. Louvis, E.; Fox, P.; Sutcliffe, C.J. Selective laser melting of aluminium components. J. Mater. Process. Technol. 2011, $211,275-284$. [CrossRef]

266. Spierings, A.; Dawson, K.; Heeling, T.; Uggowitzer, P.; Schäublin, R.; Palm, F.; Wegener, K. Microstructural features of Sc- and Zr-modified Al-Mg alloys processed by selective laser melting. Mater. Des. 2017, 115, 52-63. [CrossRef]

267. Siddique, S.; Wycisk, E.; Frieling, G.; Emmelmann, C.; Walther, F. Microstructural and Mechanical Properties of Selective Laser Melted Al 4047. Appl. Mech. Mater. 2015, 752-753, 485-490. [CrossRef]

268. Griffiths, S.; Rossell, M.D.; Croteau, J.; Vo, N.; Dunand, D.; Leinenbach, C. Effect of laser rescanning on the grain microstructure of a selective laser melted Al-Mg-Zr alloy. Mater. Charact. 2018, 143, 34-42. [CrossRef]

269. Qi, T.; Zhu, H.; Zhang, H.; Yin, J.; Ke, L.; Zeng, X. Selective laser melting of Al7050 powder: Melting mode transition and comparison of the characteristics between the keyhole and conduction mode. Mater. Des. 2017, 135, 257-266. [CrossRef]

270. Zhang, H.; Zhu, H.; Nie, X.; Yin, J.; Hu, Z.; Zeng, X. Effect of Zirconium addition on crack, microstructure and mechanical behavior of selective laser melted Al-Cu-Mg alloy. Scr. Mater. 2017, 134, 6-10. [CrossRef]

271. Wang, P.; Li, H.; Prashanth, K.; Eckert, J.; Scudino, S. Selective laser melting of Al-Zn-Mg-Cu: Heat treatment, microstructure and mechanical properties. J. Alloys Compd. 2017, 707, 287-290. [CrossRef]

272. Kimura, T.; Nakamoto, T. Microstructures and mechanical properties of A356 (AlSi7Mg0.3) aluminum alloy fabricated by selective laser melting. Mater. Des. 2016, 89, 1294-1301. [CrossRef]

273. Jia, Q.; Rometsch, P.; Cao, S.; Zhang, K.; Wu, X. Towards a high strength aluminium alloy development methodology for selective laser melting. Mater. Des. 2019, 174, 107775. [CrossRef]

274. Hu, Z.; Zhang, H.; Zhu, H.; Xiao, Z.; Nie, X.; Zeng, X. Microstructure, mechanical properties and strengthening mechanisms of AlCu5MnCdVA aluminum alloy fabricated by selective laser melting. Mater. Sci. Eng. A 2019, 759, 154-166. [CrossRef]

275. Thapliyal, S.; Shukla, S.; Zhou, L.; Hyer, H.; Agrawal, P.; Agrawal, P.; Komarasamy, M.; Sohn, Y.; Mishra, R.S. Design of heterogeneous structured $\mathrm{Al}$ alloys with wide processing window for laser-powder bed fusion additive manufacturing. Addit. Manuf. 2021, 42, 102002. [CrossRef]

276. Bartkowiak, K.; Ullrich, S.; Frick, T.; Schmidt, M. New Developments of Laser Processing Aluminium Alloys via Additive Manufacturing Technique. Phys. Procedia 2011, 12, 393-401. [CrossRef]

277. Shi, Y.; Rometsch, P.; Yang, K.; Palm, F.; Wu, X. Characterisation of a novel Sc and Zr modified Al-Mg alloy fabricated by selective laser melting. Mater. Lett. 2017, 196, 347-350. [CrossRef] 
278. Yang, K.; Shi, Y.; Palm, F.; Wu, X.; Rometsch, P. Columnar to equiaxed transition in Al-Mg(-Sc)-Zr alloys produced by selective laser melting. Scr. Mater. 2018, 145, 113-117. [CrossRef]

279. Bi, J.; Lei, Z.; Chen, Y.; Chen, X.; Lu, N.; Tian, Z.; Qin, X. An additively manufactured Al-14.1Mg-0.47Si-0.31Sc-0.17Zr alloy with high specific strength, good thermal stability and excellent corrosion resistance. J. Mater. Sci. Technol. 2021, 67, 23-35. [CrossRef]

280. Bi, J.; Lei, Z.; Chen, Y.; Chen, X.; Tian, Z.; Liang, J.; Qin, X.; Zhang, X. Densification, microstructure and mechanical properties of an Al-14.1Mg-0.47Si-0.31Sc-0.17Zr alloy printed by selective laser melting. Mater. Sci. Eng. A 2020, 774, 138931. [CrossRef]

281. Read, N.; Wang, W.; Essa, K.; Attallah, M. Selective laser melting of AlSi10Mg alloy: Process optimisation and mechanical properties development. Mater. Des. 2015, 65, 417-424. [CrossRef]

282. Takata, N.; Kodaira, H.; Sekizawa, K.; Suzuki, A.; Kobashi, M. Change in microstructure of selectively laser melted AlSi10Mg alloy with heat treatments. Mater. Sci. Eng. A 2017, 704, 218-228. [CrossRef]

283. Liu, Y.; Liu, Z.; Jiang, Y.; Wang, G.; Yang, Y.; Zhang, L. Gradient in microstructure and mechanical property of selective laser melted AlSi10Mg. J. Alloys Compd. 2018, 735, 1414-1421. [CrossRef]

284. Prashanth, K.; Scudino, S.; Klauss, H.; Surreddi, K.; Löber, L.; Wang, Z.; Chaubey, A.; Kühn, U.; Eckert, J. Microstructure and mechanical properties of Al-12Si produced by selective laser melting: Effect of heat treatment. Mater. Sci. Eng. A 2014, 590, 153-160. [CrossRef]

285. Buchbinder, D.; Meiners, W. Rapid Manufacturing of Aluminium Components for Series Production with Good Prospects; idw Informationsdienst Wissenschaft: Aachen, Germany, 2008.

286. Wong, M.; Tsopanos, S.; Sutcliffe, C.J.; Owen, I. Selective laser melting of heat transfer devices. Rapid Prototyp. J. 2007, 13, $291-297$. [CrossRef]

287. Olakanmi, E.O. Selective laser sintering/melting (SLS/SLM) of pure Al, Al-Mg, and Al-Si powders: Effect of processing conditions and powder properties. J. Mater. Process. Technol. 2013, 213, 1387-1405. [CrossRef]

288. Zheng, L.; Liu, Y.; Sun, S.; Zhang, H. Selective laser melting of Al-8.5Fe-1.3V-1.7Si alloy: Investigation on the resultant microstructure and hardness. Chin. J. Aeronaut. 2015, 28, 564-569. [CrossRef]

289. Mishra, R.S.; Thapliyal, S. Design approaches for printability-performance synergy in Al alloys for laser-powder bed additive manufacturing. Mater. Des. 2021, 204, 109640. [CrossRef]

290. Zhou, S.; Su, Y.; Wang, H.; Enz, J.; Ebel, T.; Yan, M. Selective laser melting additive manufacturing of 7xxx series Al-Zn-Mg-Cu alloy: Cracking elimination by co-incorporation of Si and TiB2. Addit. Manuf. 2020, 36, 101458. [CrossRef]

291. Gharbi, O.; Kairy, S.K.; De Lima, P.R.; Jiang, D.; Nicklaus, J.; Birbilis, N. Microstructure and corrosion evolution of additively manufactured aluminium alloy AA7075 as a function of ageing. npj Mater. Degrad. 2019, 3, 1-11. [CrossRef]

292. Brandl, E.; Heckenberger, U.; Holzinger, V.; Buchbinder, D. Additive manufactured AlSi10Mg samples using Selective Laser Melting (SLM): Microstructure, high cycle fatigue, and fracture behavior. Mater. Des. 2012, 34, 159-169. [CrossRef]

293. Li, W.; Li, S.; Liu, J.; Zhang, A.; Zhou, Y.; Wei, Q.; Yan, C.; Shi, Y. Effect of heat treatment on AlSi10Mg alloy fabricated by selective laser melting: Microstructure evolution, mechanical properties and fracture mechanism. Mater. Sci. Eng. A 2016, 663, 116-125. [CrossRef]

294. Rosenthal, I.; Stern, A.; Frage, N. Microstructure and Mechanical Properties of AlSi10Mg Parts Produced by the Laser Beam Additive Manufacturing (AM) Technology. Metall. Microstruct. Anal. 2014, 3, 448-453. [CrossRef]

295. Reschetnik, W.; Brüggemann, J.-P.; Aydinöz, M.; Grydin, O.; Hoyer, K.-P.; Kullmer, G.; Richard, H. Fatigue crack growth behavior and mechanical properties of additively processed EN AW-7075 aluminium alloy. Procedia Struct. Integr. 2016, 2, 3040-3048. [CrossRef]

296. Pantelejev, L.; Koutný, D.; Paloušek, D.; Kaiser, J. Mechanical and Microstructural Properties of 2618 Al-Alloy Processed by SLM Remelting Strategy. Mater. Sci. Forum 2017, 891, 343-349. [CrossRef]

297. Croteau, J.R.; Griffiths, S.; Rossell, M.D.; Leinenbach, C.; Kenel, C.; Jansen, V.; Seidman, D.N.; Dunand, D.C.; Vo, N.Q. Microstructure and mechanical properties of Al-Mg-Zr alloys processed by selective laser melting. Acta Mater. 2018, 153, 35-44. [CrossRef]

298. Zhang, H.; Zhu, H.; Qi, T.; Hu, Z.; Zeng, X. Selective laser melting of high strength Al-Cu-Mg alloys: Processing, microstructure and mechanical properties. Mater. Sci. Eng. A 2016, 656, 47-54. [CrossRef]

299. Shi, Y.; Yang, K.; Kairy, S.K.; Palm, F.; Wu, X.; Rometsch, P.A. Effect of platform temperature on the porosity, microstructure and mechanical properties of an Al-Mg-Sc-Zr alloy fabricated by selective laser melting. Mater. Sci. Eng. A 2018, 732, 41-52. [CrossRef]

300. Dixit, M.; Mishra, R.; Sankaran, K. Structure-property correlations in Al 7050 and Al 7055 high-strength aluminum alloys. Mater. Sci. Eng. A 2008, 478, 163-172. [CrossRef]

301. Agrawal, P.; Gupta, S.; Thapliyal, S.; Shukla, S.; Haridas, R.S.; Mishra, R.S. Additively manufactured novel Al-Cu-Sc-Zr alloy: Microstructure and mechanical properties. Addit. Manuf. 2021, 37, 101623. [CrossRef]

302. Karg, M.C.H.; Ahuja, B.; Wiesenmayer, S.; Kuryntsev, S.V.; Schmidt, M. Effects of Process Conditions on the Mechanical Behavior of Aluminium Wrought Alloy EN AW-2219 (AlCu6Mn) Additively Manufactured by Laser Beam Melting in Powder Bed. Micromachines 2017, 8, 23. [CrossRef]

303. Maamoun, A.H.; Xue, Y.F.; Elbestawi, M.A.; Veldhuis, S.C. The Effect of Selective Laser Melting Process Parameters on the Microstructure and Mechanical Properties of Al6061 and AlSi10Mg Alloys. Materials 2018, 12, 12. [CrossRef] 
304. Zhou, L.; Hyer, H.; Park, S.; Pan, H.; Bai, Y.; Rice, K.P.; Sohn, Y. Microstructure and mechanical properties of Zr-modified aluminum alloy 5083 manufactured by laser powder bed fusion. Addit. Manuf. 2019, 28, 485-496. [CrossRef]

305. Martin, J.H.; Yahata, B.D.; Hundley, J.M.; Mayer, J.; Schaedler, T.A.; Pollock, T.M. 3D printing of high-strength aluminium alloys. Nat. Cell Biol. 2017, 549, 365-369. [CrossRef]

306. Zhou, L.; Pan, H.; Hyer, H.; Park, S.; Bai, Y.; McWilliams, B.; Cho, K.; Sohn, Y. Microstructure and tensile property of a novel AlZnMgScZr alloy additively manufactured by gas atomization and laser powder bed fusion. Scr. Mater. 2019, 158, 24-28. [CrossRef]

307. Zhou, L.; Huynh, T.; Park, S.; Hyer, H.; Mehta, A.; Song, S.; Bai, Y.; McWilliams, B.; Cho, K.; Sohn, Y. Laser powder bed fusion of Al-10 wt.\% Ce alloys: Microstructure and tensile property. J. Mater. Sci. 2020, 55, 14611-14625. [CrossRef]

308. Zhou, L.; Hyer, H.; Thapliyal, S.; Mishra, R.S.; McWilliams, B.; Cho, K.; Sohn, Y. Process-Dependent Composition, Microstructure, and Printability of Al-Zn-Mg and Al-Zn-Mg-Sc-Zr Alloys Manufactured by Laser Powder Bed Fusion. Metall. Mater. Trans. A 2020, 51, 3215-3227. [CrossRef]

309. Loginova, I.S.; Sazerat, M.V.; Loginov, P.A.; Pozdniakov, A.V.; Popov, N.A.; Solonin, A.N. Evaluation of Microstructure and Hardness of Novel Al-Fe-Ni Alloys with High Thermal Stability for Laser Additive Manufacturing. JOM 2020, 72, $3744-3752$. [CrossRef]

310. Bi, J.; Lei, Z.; Chen, Y.; Chen, X.; Tian, Z.; Lu, N.; Qin, X.; Liang, J. Microstructure, tensile properties and thermal stability of AlMgSiScZr alloy printed by laser powder bed fusion. J. Mater. Sci. Technol. 2021, 69, 200-211. [CrossRef]

311. Griffiths, S.; Croteau, J.; Rossell, M.; Erni, R.; De Luca, A.; Vo, N.; Dunand, D.; Leinenbach, C. Coarsening- and creep resistance of precipitation-strengthened Al-Mg-Zr alloys processed by selective laser melting. Acta Mater. 2020, 188, 192-202. [CrossRef]

312. Lam, L.; Zhang, D.; Liu, Z.; Chua, C.K. Phase analysis and microstructure characterisation of AlSi10Mg parts produced by Selective Laser Melting. Virtual Phys. Prototyp. 2015, 10, 207-215. [CrossRef]

313. Kempen, K.; Thijs, L.; Van Humbeeck, J.; Kruth, J.-P. Mechanical Properties of AlSi10Mg Produced by Selective Laser Melting. Phys. Procedia 2012, 39, 439-446. [CrossRef]

314. Buchbinder, D.; Meiners, W.; Wissenbach, K.; Poprawe, R. Selective laser melting of aluminum die-cast alloy-Correlations between process parameters, solidification conditions, and resulting mechanical properties. J. Laser Appl. 2015, 27, S29205. [CrossRef]

315. Bai, Y.; Yang, Y.; Xiao, Z.; Zhang, M.; Wang, D. Process optimization and mechanical property evolution of AlSiMg0.75 by selective laser melting. Mater. Des. 2018, 140, 257-266. [CrossRef]

316. Aboulkhair, N.T.; Maskery, I.; Tuck, C.; Ashcroft, I.; Everitt, N. Improving the fatigue behaviour of a selectively laser melted aluminium alloy: Influence of heat treatment and surface quality. Mater. Des. 2016, 104, 174-182. [CrossRef]

317. Gu, D.; Zhang, H.; Dai, D.; Ma, C.; Zhang, H.; Li, Y.; Li, S. Anisotropic corrosion behavior of Sc and Zr modified Al-Mg alloy produced by selective laser melting. Corros. Sci. 2020, 170, 108657. [CrossRef]

318. Murr, L.E.; Gaytan, S.M.; Ramirez, D.A.; Martinez, E.; Martinez, J.L.; Hernandez, D.H.; Machado, B.I.; Medina, F.; Wicker, R.B. Microstructure architecture development in metals and alloys by additive manufacturing using electron beam melting. In 2010 Solid Freeform Fabrication Symposium; University of Texas at Austin: Austin, TX, USA, 2010; Volume 2, pp. $308-331$.

319. Frigola, P.; Harrysson, O.; Horn, T.; West, H.; Aman, R.; Rigsbee, J.; Ramirez, D.; Medina, F.; Wicker, R.; Rodriguez, E. Fabricating Copper Components. Adv. Mater. Process. 2014, 20-24.

320. Ramirez, D.; Murr, L.; Li, S.; Tian, Y.; Martinez, E.; Martinez, J.; Machado, B.; Gaytan, S.; Medina, F.; Wicker, R. Open-cellular copper structures fabricated by additive manufacturing using electron beam melting. Mater. Sci. Eng. A 2011, 528, 5379-5386. [CrossRef]

321. Lodes, M.A.; Guschlbauer, R.; Körner, C. Process development for the manufacturing of $99.94 \%$ pure copper via selective electron beam melting. Mater. Lett. 2015, 143, 298-301. [CrossRef]

322. Jadhav, S.D.; Goossens, L.R.; Kinds, Y.; Van Hooreweder, B.; Vanmeensel, K. Laser-based powder bed fusion additive manufacturing of pure copper. Addit. Manuf. 2021, 42, 101990. [CrossRef]

323. Silbernagel, C.; Gargalis, L.; Ashcroft, I.; Hague, R.; Galea, M.; Dickens, P. Electrical resistivity of pure copper processed by medium-powered laser powder bed fusion additive manufacturing for use in electromagnetic applications. Addit. Manuf. 2019, 29, 100831. [CrossRef]

324. Tang, Y.; Loh, H.; Wong, Y.; Fuh, J.; Lu, L.; Wang, X. Direct laser sintering of a copper-based alloy for creating three-dimensional metal parts. J. Mater. Process. Technol. 2003, 140, 368-372. [CrossRef]

325. Demeneghi, G.; Barnes, B.; Gradl, P.; Mayeur, J.R.; Hazeli, K. Size effects on microstructure and mechanical properties of additively manufactured copper-chromium-niobium alloy. Mater. Sci. Eng. A 2021, 820, 141511. [CrossRef]

326. Bai, Y.; Zhao, C.; Zhang, Y.; Chen, J.; Wang, H. Additively manufactured CuCrZr alloy: Microstructure, mechanical properties and machinability. Mater. Sci. Eng. A 2021, 819, 141528. [CrossRef]

327. Robinson, J.; Arjunan, A.; Stanford, M.; Lyall, I.; Williams, C. Effect of silver addition in copper-silver alloys fabricated by laser powder bed fusion in situ alloying. J. Alloys Compd. 2021, 857, 157561. [CrossRef]

328. Mridha, S.; Sadeghilaridjani, M.; Mukherjee, S. Activation Volume and Energy for Dislocation Nucleation in Multi-Principal Element Alloys. Metals 2019, 9, 263. [CrossRef]

329. Sadeghilaridjani, M.; Ayyagari, A.; Muskeri, S.; Hasannaeimi, V.; Salloom, R.; Chen, W.-Y.; Mukherjee, S. Ion irradiation response and mechanical behavior of reduced activity high entropy alloy. J. Nucl. Mater. 2020, 529, 151955. [CrossRef] 
330. Sadeghilaridjani, M.; Pole, M.; Jha, S.; Muskeri, S.; Ghodki, N.; Mukherjee, S. Deformation and tribological behavior of ductile refractory high-entropy alloys. Wear 2021, 478-479, 203916. [CrossRef]

331. Patel, K.; Sadeghilaridjani, M.; Pole, M.; Mukherjee, S. Hot corrosion behavior of refractory high entropy alloys in molten chloride salt for concentrating solar power systems. Sol. Energy Mater. Sol. Cells 2021, 230, 111222. [CrossRef]

332. Sadeghilaridjani, M.; Muskeri, S.; Hasannaeimi, V.; Pole, M.; Mukherjee, S. Strain rate sensitivity of a novel refractory high entropy alloy: Intrinsic versus extrinsic effects. Mater. Sci. Eng. A 2019, 766, 138326. [CrossRef]

333. Muskeri, S.; Hasannaeimi, V.; Salloom, R.; Sadeghilaridjani, M.; Mukherjee, S. Small-scale mechanical behavior of a eutectic high entropy alloy. Sci. Rep. 2020, 10, 2669. [CrossRef]

334. Pole, M.; Sadeghilaridjani, M.; Shittu, J.; Ayyagari, A.; Mukherjee, S. High temperature wear behavior of refractory high entropy alloys based on 4-5-6 elemental palette. J. Alloys Compd. 2020, 843, 156004. [CrossRef]

335. Sadeghilaridjani, M.; Mukherjee, S. High-Temperature Nano-Indentation Creep Behavior of Multi-Principal Element Alloys under Static and Dynamic Loads. Metals 2020, 10, 250. [CrossRef]

336. Sadeghilaridjani, M.; Muskeri, S.; Pole, M.; Mukherjee, S. High-Temperature Nano-Indentation Creep of Reduced Activity High Entropy Alloys Based on 4-5-6 Elemental Palette. Entropy 2020, 22, 230. [CrossRef] [PubMed]

337. Sadeghilaridjani, M.; Mukherjee, S. Strain Gradient Plasticity in Multiprincipal Element Alloys. JOM 2019, 71, $3466-3472$. [CrossRef]

338. Shittu, J.; Pole, M.; Cockerill, I.; Sadeghilaridjani, M.; Reddy, L.V.K.; Manivasagam, G.; Singh, H.; Grewal, H.S.; Arora, H.S.; Mukherjee, S. Biocompatible High Entropy Alloys with Excellent Degradation Resistance in a Simulated Physiological Environment. ACS Appl. BioMater. 2020, 3, 8890-8900. [CrossRef]

339. Shittu, J.; Sadeghilaridjani, M.; Pole, M.; Muskeri, S.; Ren, J.; Liu, Y.; Tahoun, I.; Arora, H.; Chen, W.; Dahotre, N.; et al. Tribo-corrosion response of additively manufactured high-entropy alloy. npj Mater. Degrad. 2021, 5, 31. [CrossRef]

340. Barron, P.; Carruthers, A.; Fellowes, J.; Jones, N.; Dawson, H.; Pickering, E. Towards V-based high-entropy alloys for nuclear fusion applications. Scr. Mater. 2020, 176, 12-16. [CrossRef]

341. Yang, T.; Zhao, Y.; Luan, J.; Han, B.; Wei, J.; Kai, J.; Liu, C. Nanoparticles-strengthened high-entropy alloys for cryogenic applications showing an exceptional strength-ductility synergy. Scr. Mater. 2019, 164, 30-35. [CrossRef]

342. Geanta, V.; Voiculescu, I.; Vizureanu, P.; Sandu, A.V. High Entropy Alloys for Medical Applications. In Engineering Steels and High Entropy-Alloys; IntechOpen: London, UK, 2020; pp. 4-12.

343. Fujieda, T.; Shiratori, H.; Kuwabara, K.; Kato, T.; Yamanaka, K.; Koizumi, Y.; Chiba, A. First demonstration of promising selective electron beam melting method for utilizing high-entropy alloys as engineering materials. Mater. Lett. 2015, 159, 12-15. [CrossRef]

344. Kuwabara, K.; Shiratori, H.; Fujieda, T.; Yamanaka, K.; Koizumi, Y.; Chiba, A. Mechanical and corrosion properties of AlCoCrFeNi high-entropy alloy fabricated with selective electron beam melting. Addit. Manuf. 2018, 23, 264-271. [CrossRef]

345. Shiratori, H.; Fujieda, T.; Yamanaka, K.; Koizumi, Y.; Kuwabara, K.; Kato, T.; Chiba, A. Relationship between the microstructure and mechanical properties of an equiatomic AlCoCrFeNi high-entropy alloy fabricated by selective electron beam melting. Mater. Sci. Eng. A 2016, 656, 39-46. [CrossRef]

346. Wang, P.; Huang, P.; Ng, F.L.; Sin, W.J.; Lu, S.; Nai, M.L.S.; Dong, Z.; Wei, J. Additively manufactured CoCrFeNiMn high-entropy alloy via pre-alloyed powder. Mater. Des. 2019, 168, 107576. [CrossRef]

347. Popov, V.V., Jr.; Katz-Demyanetz, A.; Koptyug, A.; Bamberger, M. Selective electron beam melting of Al0.5CrMoNbTa0.5 high entropy alloys using elemental powder blend. Heliyon 2019, 5, e01188. [CrossRef]

348. Fujieda, T.; Shiratori, H.; Kuwabara, K.; Hirota, M.; Kato, T.; Yamanaka, K.; Koizumi, Y.; Chiba, A.; Watanabe, S. CoCrFeNiTi-based high-entropy alloy with superior tensile strength and corrosion resistance achieved by a combination of additive manufacturing using selective electron beam melting and solution treatment. Mater. Lett. 2017, 189, 148-151. [CrossRef]

349. Gu, D.; Shen, Y. Balling phenomena in direct laser sintering of stainless steel powder: Metallurgical mechanisms and control methods. Mater. Des. 2009, 30, 2903-2910. [CrossRef]

350. Hann, D.; Iammi, J.; Folkes, J. A simple methodology for predicting laser-weld properties from material and laser parameters. J. Phys. D Appl. Phys. 2011, 44, 445401. [CrossRef]

351. Moghaddam, A.O.; Shaburova, N.A.; Samodurova, M.N.; Abdollahzadeh, A.; Trofimov, E.A. Additive manufacturing of high entropy alloys: A practical review. J. Mater. Sci. Technol. 2021, 77, 131-162. [CrossRef]

352. Niu, P.; Li, R.; Yuan, T.; Zhu, S.; Chen, C.; Wang, M.; Huang, L. Microstructures and properties of an equimolar AlCoCrFeNi high entropy alloy printed by selective laser melting. Intermetallics 2019, 104, 24-32. [CrossRef]

353. Karlsson, D.; Marshal, A.; Johansson, F.; Schuisky, M.; Sahlberg, M.; Schneider, J.; Jansson, U. Elemental segregation in an AlCoCrFeNi high-entropy alloy-A comparison between selective laser melting and induction melting. J. Alloys Compd. 2019, 784, 195-203. [CrossRef]

354. Luo, S.; Zhao, C.; Su, Y.; Liu, Q.; Wang, Z. Selective laser melting of dual phase AlCrCuFeNix high entropy alloys: Formability, heterogeneous microstructures and deformation mechanisms. Addit. Manuf. 2020, 31, 100925. [CrossRef]

355. Lin, D.; Xu, L.; Jing, H.; Han, Y.; Zhao, L.; Minami, F. Effects of annealing on the structure and mechanical properties of FeCoCrNi high-entropy alloy fabricated via selective laser melting. Addit. Manuf. 2020, 32, 101058. [CrossRef]

356. Li, R.; Niu, P.; Yuan, T.; Cao, P.; Chen, C.; Zhou, K. Selective laser melting of an equiatomic CoCrFeMnNi high-entropy alloy: Processability, non-equilibrium microstructure and mechanical property. J. Alloys Compd. 2018, 746, 125-134. [CrossRef] 
357. Tong, Z.; Ren, X.; Jiao, J.; Zhou, W.; Ren, Y.; Ye, Y.; Larson, E.A.; Gu, J. Laser additive manufacturing of FeCrCoMnNi high-entropy alloy: Effect of heat treatment on microstructure, residual stress and mechanical property. J. Alloys Compd. 2019, 785, 1144-1159. [CrossRef]

358. Chew, Y.; Bi, G.; Zhu, Z.; Ng, F.; Weng, F.; Liu, S.; Nai, S.; Lee, B. Microstructure and enhanced strength of laser aided additive manufactured CoCrFeNiMn high entropy alloy. Mater. Sci. Eng. A 2019, 744, 137-144. [CrossRef]

359. Qiu, Z.; Yao, C.; Feng, K.; Li, Z.; Chu, P. Cryogenic deformation mechanism of CrMnFeCoNi high-entropy alloy fabricated by laser additive manufacturing process. Int. J. Light. Mater. Manuf. 2018, 1, 33-39. [CrossRef]

360. Xiang, S.; Li, J.; Luan, H.; Amar, A.; Lu, S.; Li, K.; Zhang, L.; Liu, X.; Le, G.; Wang, X.; et al. Effects of process parameters on microstructures and tensile properties of laser melting deposited CrMnFeCoNi high entropy alloys. Mater. Sci. Eng. A 2019, 743, 412-417. [CrossRef]

361. Xu, Z.; Zhang, H.; Du, X.; He, Y.; Luo, H.; Song, G.; Mao, L.; Zhou, T.; Wang, L. Corrosion resistance enhancement of CoCrFeMnNi high-entropy alloy fabricated by additive manufacturing. Corros. Sci. 2020, 177, 108954. [CrossRef]

362. Xu, Z.; Zhang, H.; Li, W.; Mao, A.; Wang, L.; Song, G.; He, Y. Microstructure and nanoindentation creep behavior of CoCrFeMnNi high-entropy alloy fabricated by selective laser melting. Addit. Manuf. 2019, 28, 766-771. [CrossRef]

363. Zhu, Z.G.; An, X.H.; Lu, W.J.; Li, Z.; Ng, F.L.; Liao, X.; Ramamurty, U.; Nai, S.M.L.; Wei, J. Selective laser melting enabling the hierarchically heterogeneous microstructure and excellent mechanical properties in an interstitial solute strengthened high entropy alloy. Mater. Res. Lett. 2019, 7, 453-459. [CrossRef]

364. Kim, J.G.; Park, J.M.; Seol, J.B.; Choe, J.; Yu, J.-H.; Yang, S.; Kim, H.S. Nano-scale solute heterogeneities in the ultrastrong selectively laser melted carbon-doped CoCrFeMnNi alloy. Mater. Sci. Eng. A 2020, 773, 138726. [CrossRef]

365. Park, J.M.; Choe, J.; Kim, J.G.; Bae, J.W.; Moon, J.; Yang, S.; Kim, K.T.; Yu, J.-H.; Kim, H.S. Superior tensile properties of 1\%C-CoCrFeMnNi high-entropy alloy additively manufactured by selective laser melting. Mater. Res. Lett. 2020, 8, 1-7. [CrossRef]

366. Zhou, R.; Liu, Y.; Zhou, C.; Li, S.; Wu, W.; Song, M.; Liu, B.; Liang, X.; Liaw, P. Microstructures and mechanical properties of C-containing FeCoCrNi high-entropy alloy fabricated by selective laser melting. Intermetallics 2018, 94, 165-171. [CrossRef]

367. Wu, W.; Zhou, R.; Wei, B.; Ni, S.; Liu, Y.; Song, M. Nanosized precipitates and dislocation networks reinforced C-containing CoCrFeNi high-entropy alloy fabricated by selective laser melting. Mater. Charact. 2018, 144, 605-610. [CrossRef]

368. Zhou, R.; Liu, Y.; Liu, B.; Li, J.; Fang, Q. Precipitation behavior of selective laser melted FeCoCrNiC0.05 high entropy alloy. Intermetallics 2019, 106, 20-25. [CrossRef]

369. Brif, Y.; Thomas, M.; Todd, I. The use of high-entropy alloys in additive manufacturing. Scr. Mater. 2015, 99, 93-96. [CrossRef]

370. Kuzminova, Y.; Firsov, D.; Dudin, A.; Sergeev, S.; Zhilyaev, A.; Dyakov, A.; Chupeeva, A.; Alekseev, A.; Martynov, D.; Akhatov, I.; et al. The effect of the parameters of the powder bed fusion process on the microstructure and mechanical properties of $\mathrm{CrFeCoNi}$ medium-entropy alloys. Intermetallics 2020, 116, 106651. [CrossRef]

371. Fujieda, T.; Chen, M.; Shiratori, H.; Kuwabara, K.; Yamanaka, K.; Koizumi, Y.; Chiba, A.; Watanabe, S. Mechanical and corrosion properties of CoCrFeNiTi-based high-entropy alloy additive manufactured using selective laser melting. Addit. Manuf. 2019, 25, 412-420. [CrossRef]

372. Zhu, Z.; Nguyen, Q.; Ng, F.; An, X.; Liao, X.; Liaw, P.; Nai, S.; Wei, J. Hierarchical microstructure and strengthening mechanisms of a CoCrFeNiMn high entropy alloy additively manufactured by selective laser melting. Scr. Mater. 2018, 154, 20-24. [CrossRef]

373. Chen, P.; Li, S.; Zhou, Y.; Yan, M.; Attallah, M.M. Fabricating CoCrFeMnNi high entropy alloy via selective laser melting in-situ alloying. J. Mater. Sci. Technol. 2020, 43, 40-43. [CrossRef]

374. Kim, Y.-K.; Choe, J.; Lee, K.-A. Selective laser melted equiatomic CoCrFeMnNi high-entropy alloy: Microstructure, anisotropic mechanical response, and multiple strengthening mechanism. J. Alloys Compd. 2019, 805, 680-691. [CrossRef]

375. Niu, P.; Li, R.; Zhu, S.; Wang, M.; Chen, C.; Yuan, T. Hot cracking, crystal orientation and compressive strength of an equimolar CoCrFeMnNi high-entropy alloy printed by selective laser melting. Opt. Laser Technol. 2020, 127, 106147. [CrossRef]

376. Sun, S.; Tian, Y.; Lin, H.; Dong, X.; Wang, Y.; Zhang, Z. Enhanced strength and ductility of bulk CoCrFeMnNi high entropy alloy having fully recrystallized ultrafine-grained structure. Mater. Des. 2017, 133, 122-127. [CrossRef]

377. Zhou, P.; Xiao, D.; Wu, Z.; Ou, X. Al0.5FeCoCrNi high entropy alloy prepared by selective laser melting with gas-atomized pre-alloy powders. Mater. Sci. Eng. A 2019, 739, 86-89. [CrossRef]

378. Sun, K.; Peng, W.; Yang, L.; Fang, L. Effect of SLM Processing Parameters on Microstructures and Mechanical Properties of Al0.5CoCrFeNi High Entropy Alloys. Metals 2020, 10, 292. [CrossRef]

379. Peyrouzet, F.; Hachet, D.; Soulas, R.; Navone, C.; Godet, S.; Gorsse, S. Selective Laser Melting of Al0.3CoCrFeNi High-Entropy Alloy: Printability, Microstructure, and Mechanical Properties. JOM 2019, 71, 3443-3451. [CrossRef]

380. Yao, H.; Tan, Z.; He, D.; Zhou, Z.; Zhou, Z.; Xue, Y.; Cui, L.; Chen, L.; Wang, G.; Yang, Y. High strength and ductility AlCrFeNiV high entropy alloy with hierarchically heterogeneous microstructure prepared by selective laser melting. J. Alloys Compd. 2020, 813, 152196. [CrossRef]

381. Agrawal, P.; Thapliyal, S.; Nene, S.; Mishra, R.; McWilliams, B.; Cho, K. Excellent strength-ductility synergy in metastable high entropy alloy by laser powder bed additive manufacturing. Addit. Manuf. 2020, 32, 101098. [CrossRef]

382. Song, M.; Zhou, R.; Gu, J.; Wang, Z.; Ni, S.; Liu, Y. Nitrogen induced heterogeneous structures overcome strength-ductility trade-off in an additively manufactured high-entropy alloy. Appl. Mater. Today 2020, 18, 100498. [CrossRef] 
383. Ren, J.; Mahajan, C.; Liu, L.; Follette, D.; Chen, W.; Mukherjee, S. Corrosion Behavior of Selectively Laser Melted CoCrFeMnNi High Entropy Alloy. Metals 2019, 9, 1029. [CrossRef]

384. Sarkar, S.; Sarswat, P.K.; Free, M.L. Elevated temperature corrosion resistance of additive manufactured single phase AlCoFeNiTiV0.9Sm0.1 and AlCoFeNiV0.9Sm0.1 HEAs in a simulated syngas atmosphere. Addit. Manuf. 2019, 30, 100902. [CrossRef]

385. Zhang, H.; Zhao, Y.; Huang, S.; Zhu, S.; Wang, F.; Li, D. Manufacturing and Analysis of High-Performance Refractory HighEntropy Alloy via Selective Laser Melting (SLM). Materials 2019, 12, 720. [CrossRef]

386. Sadeghilaridjani, M.; Ayyagari, A.; Muskeri, S.; Hasannaeimi, V.; Jiang, J.; Mukherjee, S. Small-Scale Mechanical Behavior of Ion-Irradiated Bulk Metallic Glass. JOM 2020, 72, 123-129. [CrossRef]

387. Sadeghilaridjani, M.; Kato, K.; Shinohara, T.; Yashiro, W.; Momose, A.; Kato, H. High aspect ratio grating by isochronal imprinting of less viscous workable Gd-based metallic glass for neutron phase imaging. Intermetallics 2016, 78, 55-63. [CrossRef]

388. Pauly, S.; Löber, L.; Petters, R.; Stoica, M.; Scudino, S.; Kühn, U.; Eckert, J. Processing metallic glasses by selective laser melting. Mater. Today 2013, 16, 37-41. [CrossRef]

389. Mahbooba, Z.; Thorsson, L.; Unosson, M.; Skoglund, P.; West, H.; Horn, T.; Rock, C.; Vogli, E.; Harrysson, O. Additive manufacturing of an iron-based bulk metallic glass larger than the critical casting thickness. Appl. Mater. Today 2018, 11, 264-269. [CrossRef]

390. Liang, S.-X.; Wang, X.; Zhang, W.; Liu, Y.-J.; Wang, W.; Zhang, L.-C. Selective laser melting manufactured porous Fe-based metallic glass matrix composite with remarkable catalytic activity and reusability. Appl. Mater. Today 2020, 19, 100543. [CrossRef]

391. Nong, X.; Zhou, X.; Ren, Y. Fabrication and characterization of Fe-based metallic glasses by Selective Laser Melting. Opt. Laser Technol. 2019, 109, 20-26. [CrossRef]

392. Li, N.; Zhang, J.; Xing, W.; Ouyang, D.; Liu, L. 3D printing of Fe-based bulk metallic glass composites with combined high strength and fracture toughness. Mater. Des. 2018, 143, 285-296. [CrossRef]

393. Jung, H.Y.; Choi, S.J.; Prashanth, K.G.; Stoica, M.; Scudino, S.; Yi, S.; Kühn, U.; Kim, D.H.; Kim, K.B.; Eckert, J. Fabrication of Fe-based bulk metallic glass by selective laser melting: A parameter study. Mater. Des. 2015, 86, 703-708. [CrossRef]

394. Ouyang, D.; Xing, W.; Li, N.; Li, Y.; Liu, L. Structural evolutions in 3D-printed Fe-based metallic glass fabricated by selective laser melting. Addit. Manuf. 2018, 23, 246-252. [CrossRef]

395. Hofmann, D.C.; Bordeenithikasem, P.; Pate, A.; Roberts, S.; Vogli, E. Developing Processing Parameters and Characterizing Microstructure and Properties of an Additively Manufactured FeCrMoBC Metallic Glass Forming Alloy. Adv. Eng. Mater. 2018, 20, 1800433. [CrossRef]

396. Zou, Y.; Wu, Y.; Li, K.; Tan, C.; Qiu, Z.; Zeng, D. Selective laser melting of crack-free Fe-based bulk metallic glass via chessboard scanning strategy. Mater. Lett. 2020, 272, 127824. [CrossRef]

397. Li, X.; Roberts, M.; Liu, Y.; Kang, C.; Huang, H.; Sercombe, T. Effect of substrate temperature on the interface bond between support and substrate during selective laser melting of Al-Ni-Y-Co-La metallic glass. Mater. Des. 2015, 65, 1-6. [CrossRef]

398. Prashanth, K.; Shahabi, H.S.; Attar, H.; Srivastava, V.; Ellendt, N.; Uhlenwinkel, V.; Eckert, J.; Scudino, S. Production of high strength Al85Nd8Ni5Co2 alloy by selective laser melting. Addit. Manuf. 2015, 6, 1-5. [CrossRef]

399. Li, X.; Kang, C.; Huang, H.; Zhang, L.; Sercombe, T. Selective laser melting of an A186Ni6Y4.5Co2La1.5 metallic glass: Processing, microstructure evolution and mechanical properties. Mater. Sci. Eng. A 2014, 606, 370-379. [CrossRef]

400. Li, X.; Kang, C.; Huang, H.; Sercombe, T. The role of a low-energy-density re-scan in fabricating crack-free Al85Ni5Y6Co2Fe2 bulk metallic glass composites via selective laser melting. Mater. Des. 2014, 63, 407-411. [CrossRef]

401. Li, X.; Roberts, M.; O'Keeffe, S.; Sercombe, T. Selective laser melting of Zr-based bulk metallic glasses: Processing, microstructure and mechanical properties. Mater. Des. 2016, 112, 217-226. [CrossRef]

402. Luo, Y.; Xing, L.; Jiang, Y.; Li, R.; Lu, C.; Zeng, R.; Luo, J.; Zhang, P.; Liu, W. Additive Manufactured Large Zr-Based Bulk Metallic Glass Composites with Desired Deformation Ability and Corrosion Resistance. Materials 2020, 13, 597. [CrossRef]

403. Pacheco, V.; Karlsson, D.; Marattukalam, J.J.; Stolpe, M.; Hjörvarsson, B.; Jansson, U.; Sahlberg, M. Thermal stability and crystallization of a Zr-based metallic glass produced by suction casting and selective laser melting. J. Alloys Compd. 2020, 825, 153995. [CrossRef]

404. Marattukalam, J.J.; Pacheco, V.; Karlsson, D.; Riekehr, L.; Lindwall, J.; Forsberg, F.; Jansson, U.; Sahlberg, M.; Hjörvarsson, B. Development of process parameters for selective laser melting of a Zr-based bulk metallic glass. Addit. Manuf. 2020, $33,101124$. [CrossRef]

405. Sohrabi, N.; Jhabvala, J.; Kurtuldu, G.; Stoica, M.; Parrilli, A.; Berns, S.; Polatidis, E.; Van Petegem, S.; Hugon, S.; Neels, A.; et al. Characterization, mechanical properties and dimensional accuracy of a Zr-based bulk metallic glass manufactured via laser powder-bed fusion. Mater. Des. 2021, 199, 109400. [CrossRef]

406. Deng, L.; Kosiba, K.; Limbach, R.; Wondraczek, L.; Kühn, U.; Pauly, S. Plastic deformation of a Zr-based bulk metallic glass fabricated by selective laser melting. J. Mater. Sci. Technol. 2021, 60, 139-146. [CrossRef]

407. Zhang, C.; Li, X.-M.; Liu, S.-Q.; Liu, H.; Yu, L.-J.; Liu, L. 3D printing of Zr-based bulk metallic glasses and components for potential biomedical applications. J. Alloys Compd. 2019, 790, 963-973. [CrossRef]

408. Best, J.P.; Ostergaard, H.E.; Li, B.; Stolpe, M.; Yang, F.; Nomoto, K.; Hasib, M.T.; Muránsky, O.; Busch, R.; Li, X.; et al. Fracture and fatigue behaviour of a laser additive manufactured Zr-based bulk metallic glass. Addit. Manuf. 2020, 36, 101416. [CrossRef] 
409. Bordeenithikasem, P.; Stolpe, M.; Elsen, A.; Hofmann, D.C. Glass forming ability, flexural strength, and wear properties of additively manufactured Zr-based bulk metallic glasses produced through laser powder bed fusion. Addit. Manuf. 2018, 21, 312-317. [CrossRef]

410. Deng, L.; Gebert, A.; Zhang, L.; Chen, H.; Gu, D.; Kühn, U.; Zimmermann, M.; Kosiba, K.; Pauly, S. Mechanical performance and corrosion behaviour of Zr-based bulk metallic glass produced by selective laser melting. Mater. Des. 2020, 189, 108532. [CrossRef]

411. Zhang, Y.; Lin, X.; Gao, X.; Su, X.; Guo, S.; Huang, W. Crystallization behavior of Zr55Cu30Al10Ni5 amorphous alloys produced by selective laser melting of preannealed powders. J. Alloys Compd. 2020, 819, 153013. [CrossRef]

412. Pauly, S.; Schricker, C.; Scudino, S.; Deng, L.; Kühn, U. Processing a glass-forming Zr-based alloy by selective laser melting. Mater. Des. 2017, 135, 133-141. [CrossRef]

413. Ouyang, D.; Li, N.; Xing, W.; Zhang, J.; Liu, L. 3D printing of crack-free high strength Zr-based bulk metallic glass composite by selective laser melting. Intermetallics 2017, 90, 128-134. [CrossRef]

414. Ouyang, D.; Li, N.; Liu, L. Structural heterogeneity in 3D printed Zr-based bulk metallic glass by selective laser melting. J. Alloys Compd. 2018, 740, 603-609. [CrossRef]

415. Lu, X.; Nursulton, M.; Du, Y.; Liao, W. Structural and Mechanical Characteristics of Cu50Zr43Al7 Bulk Metallic Glass Fabricated by Selective Laser Melting. Materials 2019, 12, 775. [CrossRef] [PubMed]

416. Gao, X.; Liu, Z.; Li, J.; Liu, E.; Yue, C.; Zhao, K.; Yang, G. Selective laser melting of CuZr-based metallic glass composites. Mater. Lett. 2020, 259, 126724. [CrossRef]

417. Sohrabi, N.; Jhabvala, J.; Kurtuldu, G.; Frison, R.; Parrilli, A.; Stoica, M.; Neels, A.; Löffler, J.F.; Logé, R.E. Additive manufacturing of a precious bulk metallic glass. Appl. Mater. Today 2021, 24, 101080. [CrossRef]

418. Deng, L.; Wang, S.; Wang, P.; Kühn, U.; Pauly, S. Selective laser melting of a Ti-based bulk metallic glass. Mater. Lett. 2018, 212, 346-349. [CrossRef]

419. Wang, L.; Wang, H.; Liu, Y.; Fu, Z.; Peng, T.; Shen, J.; Zhou, S.; Yan, M.; Wang, G.; Dai, Y. Selective laser melting helps fabricate record-large bulk metallic glass: Experiments, simulation and demonstrative part. J. Alloys Compd. 2019, 808, 151731. [CrossRef]

420. Best, J.P.; Evenson, Z.; Yang, F.; Dippel, A.-C.; Stolpe, M.; Gutowski, O.; Hasib, M.T.; Li, X.; Kruzic, J.J. Structural periodicity in laser additive manufactured Zr-based bulk metallic glass. Appl. Phys. Lett. 2019, 115, 031902. [CrossRef]

421. Xing, W.; Ouyang, D.; Chen, Z.; Liu, L. Effect of energy density on defect evolution in 3D printed Zr-based metallic glasses by selective laser melting. Sci. China Ser. G Phys. Mech. Astron. 2020, 63, 1-7. [CrossRef]

422. Nam, Y.G.; Koo, B.; Chang, M.S.; Yang, S.; Yu, J.; Park, Y.H.; Jeong, J.W. Selective laser melting vitrification of amorphous soft magnetic alloys with help of double-scanning-induced compositional homogeneity. Mater. Lett. 2020, 261, 127068. [CrossRef]

423. Best, J.P.; Ast, J.; Li, B.; Stolpe, M.; Busch, R.; Yang, F.; Li, X.; Michler, J.; Kruzic, J.J. Relating fracture toughness to micro-pillar compression response for a laser powder bed additive manufactured bulk metallic glass. Mater. Sci. Eng. A 2020, $770,138535$. [CrossRef]

424. Zhang, C.; Ouyang, D.; Pauly, S.; Liu, L. 3D printing of bulk metallic glasses. Mater. Sci. Eng. R Rep. 2021, 145, 100625. [CrossRef]

425. Karlsson, J.; Snis, A.; Engqvist, H.; Lausmaa, J. Characterization and comparison of materials produced by Electron Beam Melting (EBM) of two different Ti-6Al-4V powder fractions. J. Mater. Process. Technol. 2013, 213, 2109-2118. [CrossRef]

426. Xi, L.; Chen, S.; Wei, M.; Liang, J.; Liu, C.; Wang, M. Microstructural Evolution and Properties of 24CrNiMoY Alloy Steel Fabricated by Selective Laser Melting. J. Mater. Eng. Perform. 2019, 28, 5521-5532. [CrossRef]

427. Wang, Y.; Li, R.; Niu, P.; Zhang, Z.; Yuan, T.; Yuan, J.; Li, K. Microstructures and properties of equimolar AlCoCrCuFeNi high-entropy alloy additively manufactured by selective laser melting. Intermetallics 2020, 120, 106746. [CrossRef]

428. Yang, X.; Zhou, Y.; Xi, S.; Chen, Z.; Wei, P.; He, C.; Li, T.; Gao, Y.; Wu, H. Additively manufactured fine grained Ni6Cr4WFe9Ti high entropy alloys with high strength and ductility. Mater. Sci. Eng. A 2019, 767, 138394. [CrossRef]

429. Ettefagh, A.H.; Guo, S.; Raush, J. Corrosion performance of additively manufactured stainless steel parts: A review. Addit. Manuf. 2021, 37, 101689. [CrossRef] 